\title{
IMPORTÂNCIA DE COMPOSTOS ORGANOSSULFURADOS EM SEMENTES DE LEGUMINOSAS E EM OUTROS VEGETAIS
}

URSULA MARIA LANFER MARQUEZ

Tese apresentada à Comissão Julgadora do Concurso para Livre-Docência junto à área de Química e Bioquímica de Alimentos do Departamento de Alimentos e Nutrição Experimental da Faculdade de Ciências Farmacêuticas da Universidade de São Paulo

SÃO PAULO

2000 


\section{Dedico esta Tese e Agradeço:}

Àqueles com os quais convivo, convivi e vi nascer.

"Para atingir a autonomia os individuos devem cultivar o servir, a renúncia, a verdade, a não violência, o autodomínio e a paciência"

(Mohandas Karamchand Gandhi) 
Meus singelos Agradecimentos aos Professores e colegas pelo apoio direto ou indireto, incentivo, estímulo e amizade durante toda a minha vida acadêmica.

"A ciência é um acúmulo de visão: se vi mais longe que os outros, foi porque subi sobre os ombros de gigantes"

(Isaac Newton) 
Faço Agradecimentos calorosos aos meus Alunos e Orientados de PósGraduação pelo convívio diário, troca de idéias e aprendizado mútuo.

"O direito de investigar, a oportunidade de ensaiar, o privilégio de errar e a coragem de tornar a experimentar. É esse o segredo dos homens livres"

(Roger Bacon) 
Meus sinceros Agradecimentos às Secretárias do Departamento de Alimentos da FCF da USP pela dedicação, presteza e competência com que sempre me atenderam.

"A palavra escrita não apenas permanece, mas ela floresce e está sendo revigorada pela revolução digital. É a imortalidade do texto"

(Paul Saffo)

*

Agradecimentos aos Funcionários do Departamento de Alimentos $e$ Nutrição Experimental pela ajuda e auxílio, sempre com alegria, quando deles precisei.

Uma tecnologia espetacular automatizada, foi criada de três décadas para cá, que facilitou o trabalho e abreviou o tempo, para alcançar o objetivo proposto. 
Agradeço à FAPESP, à CAPES e ao CNPq, pelo auxílio financeiro, sem o qual não teria sido possivel a realização dos trabalhos desta Tese.

Quando o Decano da Sorbonne disse a Pierre e Marie Curie, que o Ministério da França iria colocar os seus nomes na Legião de Honra, estes responderam:

"Não temos vontade de ser condecorados, mas estamos precisando desesperadamente de um bom laboratório".

(Pierre e Manya Sklodovska Curie) 
Meus Agradecimentos especiais

Profa. Marilene de Vuono Camargo Penteado

Prof. Jorge Mancini Filho

Prof. Franco Maria Lajolo

Profa. Maria Thereza Macchini Miranda

Profa. Primavera Borelli

Pesquisador Roberto Tetsuo Tanaka

Pesquisador Nelson da Silva Fonseca Junior

Pesquisadora Vânia Moda Cirino

Prof. Kyomi Koide

Prof. Eduardo L.A. Macchione

Profa. Susanna Salém Vasconcelos

Profa. Sílvia Berlanga Barros

Profa. Maria Lúcia Zaidan Dagli

Prof. José Luiz Guerra

Profa. Tullia M.C.C.Filisetti

Profa. Elfriede Marianne Bacchi

Rosa Maria Cerdeira Barros

Isabel Cristina Bossi Alves

Ângela Maria Lima de Oliveira

Mônica Dealis Perussi

Inês Maria Henrique

Maria Inês A. Gonçalves

Silvânia Neves

Leila Aparecida Bonadio 


\section{SUMÁRIO}

Introdução Geral.

\section{PARTE I}

Estudo crítico comparativo dos compostos organossulfurados em vegetais.

1. Efeitos biológicos dos aminoácidos e peptídeos $\gamma$-glutamil sulfurados.

2. Metabolização da metionina em mamíferos.

3. Absorção e metabolização da S-metil-L-cisteína em mamíferos.

4. Efeitos tóxicos da metionina e da S-metil-L-cisteína em mamíferos.

5. Função e metabolização de aminoácidos e peptídeos $\gamma$-glutamil sulfurados em vegetais

6. Biossíntese e metabolização de compostos organossulfurados em vegetais.

\section{PARTE II}

Concentração e importância de aminoácidos e peptídeos $\gamma$-glutamil sulfurados em sementes de leguminosas.

1. Introdução

2. Objetivos

2.1 Geral

2.2 Especificos.

\section{Material e Métodos}

3. 1 Feijões.

3.2 Pantio do feijão Phaseolus vulgaris L., em diferentes localidades do

Estado do Paraná

3.3 Plantio do feijão Phaseolus vulgaris L. em solos com diferentes concentrações de enxofre.

3.4 Preparo das farinhas de feijões.

3.5 Composição centesimal. 
3.6 Composição em aminoácidos.

3.7 Extração dos aminoácidos e peptídeos $\gamma$-glutamil sulfurados - Obtenção do Extrato Bruto (EB) ................................................................ 56

3.8 Purificação parcial do Extrato Bruto....................................................... 57

3.9 Identificação da S-metil-L-cisteína e da $\gamma$-glutamil-S-metil-L-cisteina...... 58

3.10 Quantificação da S-metil-L-cisteína e da $\gamma$-glutamil-S-metil-L-cisteína... 59

3.11 Identificação e quantificação da metionina e da $\gamma$-glutamil-L-metionina.. $\quad 59$

3.12 Estabilidade da $\gamma$-glutamil-L-metionina durante o cozimento de sementes de Vigna mungo.

60

\section{Resultados e Discussão}

4.1 Efeito do plantio das sementes do Phaseolus vulgaris L., em diferentes regiões sobre a concentração do peptídeo $\gamma$-glutamil-S-metil-L-cisteina e o aminoácido S-metil-L-cisteína.

4.2 Efeito do plantio do feijão Phaseolus vulgaris L., em solos com diferentes concentrações de enxofre sobre a concentração do peptídeo $\gamma$-glutamil-Smetil-L-cisteína e o aminoácido S-metil-L-cisteína

4.3 Sementes de Vigna mungo (L.) Hepper e Vigna radiata (L.), R.

Willczeck, como alternativa ao consumo do habitual feijão Phaseolus vulgaris, L....

5. Conclusões

6. Resumo

7. Summary

8. Referências Bibliográficas. 


\section{LISTA DE FIGURAS:}

Figura 1. Curva de crescimento dos animais alimentados com rações suplementadas com S-metil-L-cisteina (SMC) e aminoácidos protéicos.

Figura 2. Curva de crescimento dos animais que receberam rações suplementadas com 0,6 e 1,2\% de S-metil-L-cisteína (SMC) em comparação aos controles "pair fed"

Figura 3. Metabolismo da metionina em mamíferos, via transsulfuração. (Adaptado de GAHL et al., 1987).

Figura 4. Metabolismo da metionina em mamíferos, via transaminação. (Adaptado de Scislowski \& Pickard, 1994).

Figura 5. Digestão e absorção de proteinas no intestino delgado. (Ganapathy et al., 1994).

Figura 6. Concentração de metionina ( $\mu$ moles/mL) no sangue periférico após administração de $66 \mu$ moles $(9,8 \mathrm{mg})$ do aminoácido por sonda gástrica.

Figura 7. Concentração de S-metil-L-cisteína ( $\mu$ moles/mL) no sangue periférico após administração de $66 \mu$ moles $(8,9 \mathrm{mg})$ do aminoácido por sonda gástrica.........

Figura 8. Concentração de S-metil-L-cisteína $(\mu \mathrm{moles} / \mathrm{mL})$ no sangue periférico após administração de $66 \mu$ moles $(17,4 \mathrm{mg})$ do peptídeo no extrato bruto por sonda gástrica

Figura 9. Aminograma do Extrato Bruto das sementes germinadas. $1^{\circ}$ dia (A), $2^{\circ}$ $\operatorname{dia}(\mathrm{B})$ e $3^{\circ} \mathrm{dia}(\mathrm{C})$

Figura 10. Aminograma do Extrato Bruto das sementes germinadas $4^{\circ}$ dia (D), $5^{\circ}$ dia (E)

Figura 11. Análogos de aminoácidos protéicos que apresentam atividade tóxica (Rosenthal \& Bell, 1979; D'Mello, 1992).

Figura 12: Biossíntese de precursores de aminoácidos e peptídeos sulfurados no gênero Allium. (Adaptado de Block, 1992)

Figura 13. Estado do Paraná e localização das regiões de cultivo. 
Figura 14. Fluxograma de extração de peptídeos $\gamma$-glutamil peptideos e obtenção do ExtratoBruto (EB)

Figura 15. Esquema de purificação do Extrato Bruto.

Figura 16. Mecanismo proposto para a biossintese e metabolização do peptídeo $\gamma$-glutamil-S-metil-L-cisteina e da S-metil-L-cisteina livre.

Figura 17. Morfologia das sementes Vigna radiata e Vigna mungo

Figura 18. Aminograma dos Extratos Brutos não hidrolisados de Vigna mungo Cultivar Preto (A) e Vigna radiata (B)

Figura 19. Extrato Bruto não hidrolisado (A) e Extrato Bruto hidrolisado (B) da Vigna mungo 


\section{LISTA DE TABELAS:}

Tabela 1. NPR das rações suplementadas com S-metil-L-cisteina e aminoácidos sulfurados proteicos.

Tabela 2. Efeito dose-dependente da S-metilcisteína (SMC)

Tabela 3. Classificação dos sistemas de transporte de aminoácidos na bordadura em escova da membrana das células do intestino delgado.

Tabela 4. Teores de $\gamma$-glutamil-S-metil-L-cisteina ( $\gamma$-glutamil-SMC) e de $S$ metil-L-cisteina (SMC) em leguminosas comestiveis

Tabela 5. Localização geográfica de plantio das sementes do feijão Phaseolus vulgaris $\mathrm{L}$.

Tabela 6. Conteúdo de umidade e proteina no feijão Phaseohs vulgaris L., variedades Carioca e lapar-14 cultivadas em diversas regiões do Estado do Paraná

Tabela 7. Teor de $\gamma$-glutamil-S-metil-L-cisteina ( $\gamma$-glutamil-SMC) e de S-metilL-cisteína (SMC) livre no feijão Phaseolus vulgaris L., variedades Carioca e lapar, cultivadas em diversas localidades do Estado do Paraná

Tabela 8. Influência da adubação do solo com enxofre nos conteúdos do peptídeo $\gamma$-glutamil-S-metil-L-cisteina ( $\gamma$-glutamil-SMC) e de S-metil-L-cisteina (SMC) livre

Tabela 9. Influência da variedade, região de cultivo e adição de enxofre no teor do peptídeo $\gamma$-glutamil-S-metil-L-cisteina ( $\gamma$-glutamil-SMC) e S-metil-L-cisteina (SMC) livre

Tabela 10. Composição centesimal dos feijões das espécies Vigna mungo e Vigna radiata

Tabela 11. Composição de aminoácidos das farinhas de feijões das espécies Vigna mungo e Vigna radiala. 


\section{Introdução Geral}

Realizamos uma revisão critica da literatura sobre o conhecimento atual na área dos peptideos sulfurados, acrescentando os resultados dos nossos trabalhos efetuados e publicados durante os dez últimos anos, que vieram ampliar o conhecimento acumulado na bioquímica dos alimentos, específicamente no campo dos compostos organossulfurados.

Apresentamos também dois novos trabalhos que dão continuidade a esta linha de pesquisa:

- Influência regional e de adubação do solo com enxofre sobre a concentração do peptideo $\gamma$-glutamil-S-metil-L-cisteína e a S-metil-L-cisteína livre em feijão comum (Phaseolus vulgaris L.).

- Concentração e importância de áminoácidos e peptideos $\gamma$-glutamil sulfurados em sementes de Vigna mungo (L.) Hepper.

As primeiras pesquisas relativas a substâncias orgânicas sulfuradas, do metabolismo intermediário dos vegetais, datam de 1950-70. Isto ocorreu devido ao aparecimento de técnicas analíticas mais sensiveis e precisas desenvolvidas nessa época. Os estudos foram conduzidos por pesquisadores que estavam interessados em conhecer quali- e quantitativamente os constituintes intimos de diferentes plantas e suas interrelações. Além dos vintes aminoácidos protéicos conhecidos, mais de 250 aminoácidos não protëicos naturais foram identificados (KASAI et al., 1980). Juntamente com estes não protéicos, foram também descritos pequenos di- e tripeptideos, sob a forma de $\gamma$-glutamil peptídeos, isto é, peptídeos cuja ligação peptídica ocorre na posição gama.

Assim ficou claro para os pesquisadores, que além dos peptideos contendo aminoácidos protéicos como leucina, valina, fenilalanina, tirosina e metionina, os peptideos podem ser formados também através da ligação com aminoácidos não protéicos. Entre os peptídeos não protéicos formados mais frequentemente, temos aqueles que contém S-metilL-cisteina, S-alil-L-cisteina e os seus respectivos sulfóxidos. Já em 1966, WALEY publicou uma lista de vinte e cinco $\gamma$-glutamil peptídeos, contendo enxofre em sua molécula 
Os compostos organossulfurados apresentam uma ampla gama de distribuição nos vegetais, sendo que a sua presença foi detectada em vinte e uma familias, embora ocorram predominantemente nas familias Alliaceae, Leguminosae e Criciferae. Os estudos focalizaram estas famílias, devido à sua importância econômica e nutricional para a população mundial.

À família Cruciferae pertencem os vegetais comumente chamados de Brássicas (brócoli, couve, rabanete, nabo, repolho, mostarda e colza). Estes vegetais também são conhecidos, por apresentarem concentração elevada de enxofre orgânico. Em relação à colza, a maior parte do $\mathrm{S}$ encontra-se na parede das vagens, na forma de $\mathrm{SO}_{4}{ }^{2-}$ Aproximadamente $25 \%$ do conteúdo total de S encontra-se no peptídeo S-metil-L-cisteína, enquanto que os glicosinolatos são responsáveis por cerca de $8 \%$ do $\mathrm{S}$ total.

Em couves e outros vegetais folhosos, pertencentes à família Cruciferae, o peptídeo mencionado é comumente descrito como sendo o responsável pelo odor desagradável, desenvolvido durante o cozimento. As Brássicas tem sido utilizadas rotineiramente na alimentação animal, mas o gado quando é alimentado com estas plantas, desenvolve um quadro de anemia hemolítica, devido às características tóxicas conhecidas do sulfóxido de S-metil-L-cisteina, sem considerar os efeitos fisiológicos causados pelos glicosinolatos.

Na familia Alliaceae, à qual pertence o alho e a cebola, o estudo das substâncias organossulfuradas encontra-se relacionado à sua importância de serem precursores de compostos aromáticos, flavorizantes e lacrimejantes, sendo-lhes atribuida também atividade antimicrobiana. Estudos mais recentes, realizados com esta familia, apontaram diversos efeitos fisiológicos benéficos destas substâncias sulfuradas, destacando-se os efeitos hipoglicemiante, anti-colesterolêmico e anti-carcinogênico.

Em relação à família Leguminosae, existe uma enorme quantidade de espécies e variedades distribuidas pela natureza, sendo o feijão uma das espécies mais representativas. O seu estudo justifica-se, devido às suas propriedades como alimento protéico de origem vegetal para grande parte da população mundial. O seu consumo encontra-se especialmente difundido nos paises da América Latina. Mas, as sementes de leguminosas são deficientes em aminoácidos sulfurados; este fato é relevante, por constituirem fontes protéicas, ao contrário do que ocorre nas outras duas famílias anteriormente descritas, que são aceitas como condimentos, ou alimentos vegetais que fornecem sais minerais, vitaminas e fibras 
No entanto, necessita-se avaliar em profundidade a contribuição dos aminoácidos sulfurados não protéicos, presentes nessas três familias de vegetais, sob o ponto de vista nutricional e toxicológico.

Existem muitas interrogações em relação à função destes compostos sulfurados nestas famílias. Assim, pretendemos estudar estas questões o mais amplamente possível, principalmente as relacionadas com o armazenamento no vegetal de $\mathrm{N}$ e $\mathrm{S}$ na forma de substâncias orgânicas; a sua toxicidade; o seu metabolismo, tanto no animal como no vegetal; a biossintese, a sua distribuição nos vegetais e os seus efeitos biológicos nos mamiferos. 


\section{PARTE I}

\section{Estudo crítico comparativo dos compostos organossulfurados em vegetais}

\section{Efeitos biológicos dos aminoácidos e peptídeos $\gamma$-glutamil sulfurados}

Um dos assuntos mais intrigantes na literatura concernente refere-se à atividade biológica exercida pelos aminoácidos sulfurados não protéicos e pelos seus respectivos $\gamma$ glutamil peptídeos

$\mathrm{O}$ alho e a cebola vem sendo usados há milênios pela medicina popular e atualmente produtos comerciais contendo extratos desses vegetais estão sendo cada vez mais valorizados. Evidências epidemiológicas atestam um efeito anticancerígeno em pacientes portadores de tumores malignos, pelo aumento do consumo de plantas da família Alliaceae e, Organizações de Saúde, rotulam o alho e a cebola, como candidatos a "Alimentos Funcionais"

Embora o alho tenha um amplo espectro de efeitos bem documentados, os mais importantes, sob ponto de vista clínico, são os efeitos antimicrobianos, aumento da imunidade geral, efeito anticancerígeno e efeito sobre o sistema cardiovascular. (MILNER, 1996; SUNDARAM \& MILNER, 1996; MILNER, 1996; KREST \& KEUSGEN, 1999; ANKRI \& MIRELMAN, 1999; MIRELMAN, 1999; SIEGERS et al., 1999). O efeito antimicrobiano é atribuído o sulfóxido de S-metil-S-L-cisteína, como precursor do metilmetanotiosulfinato (KYUNG \& FLEMING, 1994). Pesquisadores apontam ainda outros efeitos benéficos tais como: ação hipoglicemiante, anticolesterolêmica, antifúngica $e$ inibidora de agregação plaquetária (MAW, 1982; KUMARI \& AUGUSTI; 1995; SHEELA et al., 1995; AQUEL et al., 1991). Existem ainda relatos do aumento da secreção de adrenalina e noradrenalina plasmáticas, em ratos alimentados com dieta suplementada com pó de alho ( $8 \mathrm{~g} / \mathrm{kg}$ da dieta) (OI et al., 1999). O aumento da secreção de adrenalina e noradrenalina, provoca um catabolismo dos triglicerídeos cujo efeito é um aumento termogênico, que explicaria então o efeito hipoglicêmico e hipolipidêmico.

As substâncias mais estudadas até hoje nos vegetais da familia Alliaceae são os compostos sulfurados. Eles incluem tiossulfinatos, peptideos $\gamma$-glutamil sulfurados e outros compostos sulfurados. Estima-se que $82 \%$ dos compostos sulfurados do alho correspondam à aliina (sulfóxido de S-2-propenil-L-cisteína) e aos peptídeos $\gamma$-glutamil sulfurados (WHO, 
1999). Algumas destas substâncias existem no vegetal na forma de precursores e a sua transformação nos compostos ativos, depende da forma de preparo do vegetal para consumo e da ação de enzimas específicas (KUBEC et al., 1998).

A maioria dos efeitos biológicos citados, é atribuida aos compostos sulfurados Estes, na verdade, não existem originalmente nos vegetais, mas são provenientes de certos precursores comuns, chamados genericamente de sulfóxidos de S-alc(en)il-L-cisteína. Um dos mais conhecidos e estudados é a alicina (2-propenil)-2-propenotiosulfinato) produzida pela ação da enzima aliinase atuando sobre a aliina. A aliina, por sua vez, origina-se ao menos parcialmente, de peptídeos $\gamma$-glutamil sulfurados.

De acordo com LANCASTER \& SHAW (1991), estes mesmos sulfóxidos de Salc(en)il-L-cisteína estariam relacionados também com o aroma e o sabor característicos dos vegetais que compõem esta família. Estes substratos estão localizados no citoplasma da célula, enquanto que a enzima cisteína sulfóxido liase (C-S-liase) encontra-se isolada no vacúolo. A ruptura da célula pelo corte da cebola, por exemplo, promove o contato entre a enzima e os sulfóxidos, resultando nos compostos organossulfurados voláteis, conferindo as propriedades organolépticas, caracteristicas da cebola e do alho.

Os primeiros efeitos adversos em animais atribuídos aos sulfóxidos de S-alc(en)ilcisteina, foram observados em bovinos alimentados somente com folhas de Brássicas, por um periodo de uma a três semanas. Os animais desenvolveram sintomas de anemia hemolítica aguda, iniciada com o aparecimento de agregados de hemoglobina desnaturada dentro dos eritrócitos, seguida de uma acentuada queda do nível de hemoglobina no sangue, perda de apetite, icterícia e aumento da frequência cardiaca, apresentando ainda, queda na produção de leite, baixa taxa de concepção e retardo no crescimento. Entretanto foi observado que eles geralmente se recuperaram quando a alimentação com couve era interrompida (GREENHALGH, 1969; GRIFFITHS et al., 1994).

Esses efeitos deletérios foram atribuídos ao dimetil dissulfeto e ao metanotiol, produzidos a partir do sulfóxido de S-metil-L-cisteína (sulfóxido de SMC), pela ação de bactérias presentes no rumen. Bovinos foram mais susceptiveis do que animais monogástricos, tais como o porco e o coelho. Neste caso, e ao contrário dos efeitos benéficos verificados no alho e na cebola, o dimetil-dissulfeto, que é um dos produtos de degradação da SMC, foi considerado o agente causador da intoxicação, provavelmente 
porque provocou uma diminuição dos níveis de glutationa reduzida (GSH) no eritrócito, através de sua ação oxidante, ou pela reação com grupos sulfidrila na membrana da hemácia, alterando a permeabilidade da mesma, levando à perda da capacidade do eritrócito de reter a hemoglobina (MAW, 1982, D'MELLO, 1992).

\section{$2 \mathrm{GSH}+\mathrm{CH}_{3} \mathrm{SSCH}_{3} \rightarrow \mathrm{GSSG}+2 \mathrm{CH}_{3} \mathrm{SH}$}

\section{Membrana-SH $+\mathrm{CH}_{3} \mathrm{SSCH}_{3} \rightarrow$ Membrana-SSCH $3+\mathrm{CH}_{3} \mathrm{SH}$}

Outros autores sustentam a hipótese da toxicidade da própria S-metil-L-cisteína ( SMC) mesmo no estado não oxidado, que se encontra presente em grande quantidade em certas leguminosas, como no feijão Phaseolus vilgaris L. por exemplo. FRIEDMAN \& GUMBMAN, em 1984, estudaram diversos análogos da metionina, entre eles a SMC. Eles suplementaram uma dieta à base de uma mistura de aminoácidos, deficiente em metionina, com seus análogos e observaram o crescimento de camundongos em relação ao da dieta normal. A ração, contendo $75 \%$ de SMC sintética e $25 \%$ de metionina em proporção molar, deprimiu drasticamente o crescimento dos animais que foi de apenas $13 \%$ em relação ao valor observado com a ração controle contendo $1,17 \%$ de metionina, confirmando dados anteriores de BENEVENGA et al., 1976.

Por outro lado, EYRE et al. (1983) adicionaram SMC $(0,2$ a $0,5 \%$ na ração) a diferentes fontes protéicas (albumina de ovo, proteina microbiana, Vicia faba L. e mistura de aminoácidos) e não observaram efeito tóxico em ratos, atribuindo à SMC um papel passivo.

Em vista da contradição encontrada na literatura dessa época e não tendo sido publicados mais nenhum trabalho sobre o efeito tóxico da $\mathrm{SMC}$, realizamos em nosso laboratório um trabalho, verificando o efeito fisiológico da SMC, delimitando uma possível função antinutricional em relação à cisteína e à metionina (PADOVESE, 1997; PADOVESE et al., aceito para publicação).

Verificamos o efeito da suplementação de rações de caseína (10\%) com cistina, metionina e SMC. Os ratos que receberam ração suplementada com 0,34\% de SMC tiveram o menor crescimento, inferior até, ao grupo de animais alimentados com ração de caseina 
sem nenhuma suplementação. Os animais alimentados com ração suplementada com $0,3 \%$ de cistina, foram os animais controle e tiveram, como era de se esperar, o melhor desempenho. A ração suplementada com $0,3 \%$ de cistina $+0,34 \%$ de SMC, também deprimiu o crescimento, indicando que a presença da SMC prejudicou a utilização da cistina.

O valor biológico dessas rações acompanhou o perfil de crescimento dos animais. $O$ NPR (net protein ratio = razão proteíca líquida) dos grupos tratados com rações suplementadas com SMC e com SMC + cistina (NPR = 3,58 e 4,09) respectivamente, foram significativamente inferiores ao grupo controle. $O$ grupo alimentado com ração deficiente em aminoácidos sulfurados, resultou num NPR intermediário aos dois grupos contendo SMC e SMC + cistina, mostrando mais uma vez, que a adição de SMC à uma dieta contendo cistina, prejudica a utilização da cistina.

Os perfis de crescimento dos animais e os valores de NPR estão apresentados na Figura 1 e na Tabela 1.

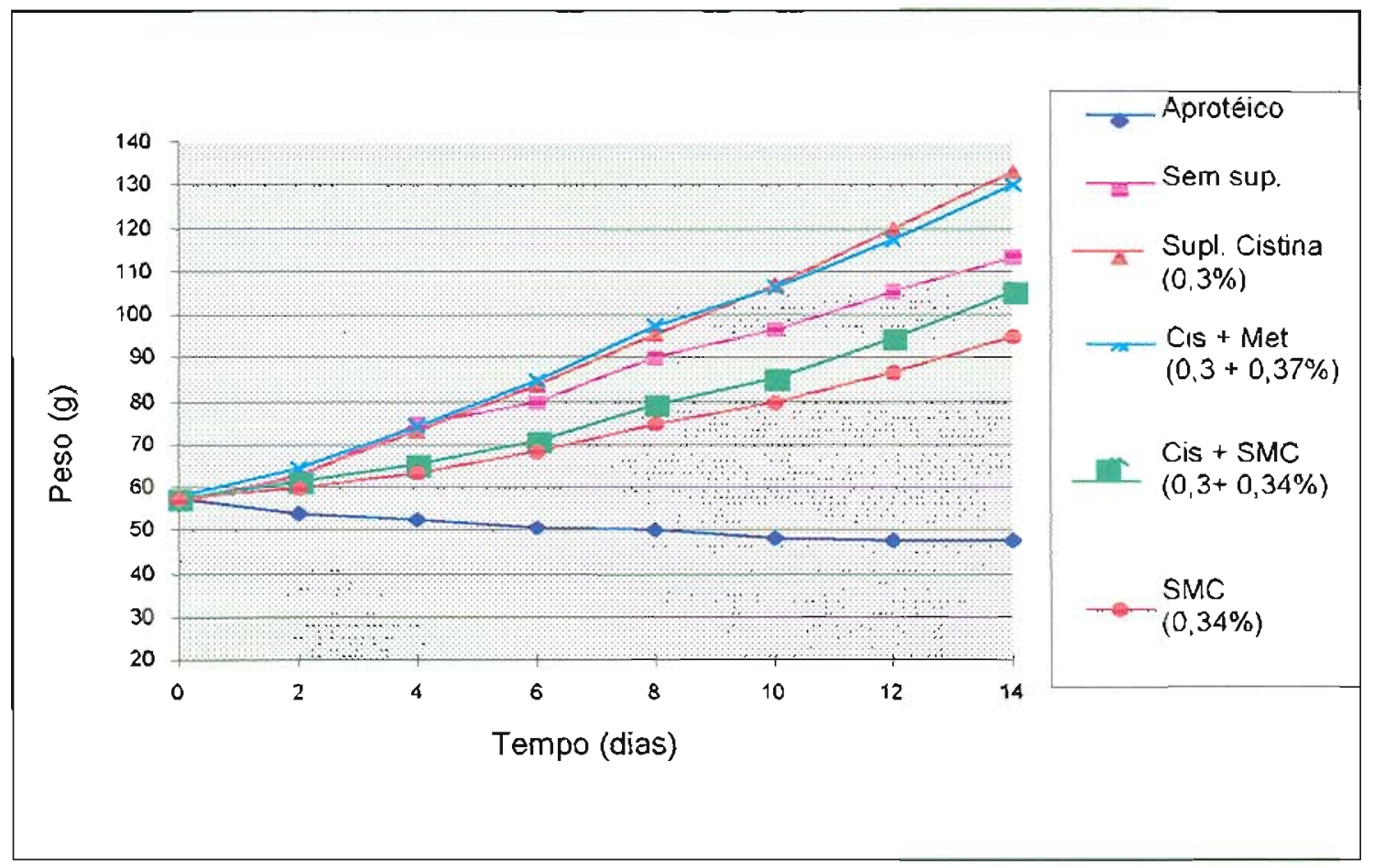

Figura 1. Curva de crescimento dos animais alimentados com rações suplementadas com S-metil-L-cisteína (SMC) e aminoácidos protéicos. 
Tabela 1. NPR das rações suplementadas com S-metil-L-cisteina (SMC) e aminoácidos sulfurados protéicos

\begin{tabular}{lccc}
\hline Dieta & $\begin{array}{r}\text { Ganho de } \\
\text { peso }(\mathrm{g})^{*}\end{array}$ & $\begin{array}{c}\text { Consumo de } \\
\text { ração }(\mathrm{g})^{*}\end{array}$ & NPR \\
\hline $10 \%$ caseina $+0,3 \%$ Cis & 76,9 & 176,0 & $4,66 \pm 0,27^{\mathrm{a}}$ \\
$10 \%$ caseina $+0,3 \%$ Cis $+0,37 \%$ Met & 72,4 & 170,1 & $4,54 \pm 0,16^{\mathrm{a}}$ \\
$10 \%$ caseina $+0,3 \%$ Cis $+0,34 \%$ SMC & 47,9 & 132,9 & $4,09 \pm 0,30^{\mathrm{b}}$ \\
$10 \%$ caseina & 56,4 & 164,5 & $3,95 \pm 0,30^{\text {hc }}$ \\
$10 \%$ caseina $+0,34 \% \mathrm{SMC}$ & 37,6 & 128,7 & $3,58 \pm 0,42^{\mathrm{C}}$ \\
\hline
\end{tabular}

Eslatística: letras diferentes indicam diferenças significativas $(\mathrm{P}<0,05)$. Ganho de peso c consumo de ração durantc um período de 14 dias.

As diferenças observadas nos valores de NPR são estatísticamente significativas $(\mathrm{P}<0,05)$, embora menos pronunciadas do que as observadas com o crescimento dos animais.

Em outro ensaio verificamos que a presença de $0,34 \%$ de SMC na ração, provocou uma depressão de $51 \%$ no ganho de peso de ratos e uma redução de $27 \%$ na ingestão voluntária de ração. Este efeito foi dependente da dose de SMC ingerida $(0,30,6,1,2$ e $2,4 \%$ na ração) e inversamente proporcional ao crescimento dos animais, como pode ser observado na Tabela 2.

Tabela 2. Efeito dose-dependente da S-metil-L-cisteina (SMC).

\begin{tabular}{lccc}
\hline Dieta & $\begin{array}{c}\text { Consumo de } \\
\text { ração }(\mathrm{g})\end{array}$ & $\begin{array}{c}\text { Ingestão de } \\
\text { SMC }(\mathrm{g})\end{array}$ & $\begin{array}{c}\text { Ganho de } \\
\text { peso }(\mathrm{g})\end{array}$ \\
\hline 10\% caseína $+0,3 \%$ de Cis & 178,3 & 0 & 74,9 \\
$10 \%$ caseína $+0,6 \%$ de SMC & 105,4 & 0,63 & 27,8 \\
$10 \%$ caseina $+1,2 \%$ de SMC & 57,4 & 0,77 & 7,3 \\
$10 \%$ caseina $+2,4 \%$ de SMC & 46,6 & 1,12 & $-4,8$ \\
\hline Consumo de ração, ingcstão de SMC c ganho de peso após um período de l4 dias.
\end{tabular}


Foi realizado outro ensaio com alimentação pareada "pair-feeding", demonstrando que os animais que receberam suplementação com 0,6 e 1,2\% de SMC na dieta, cresceram na mesma proporção que os animais dos grupos controle (caseína $+0,3 \%$ cistina), quando estes últimos tiveram a sua alimentação restrita à mesma quantidade ingerida pelos grupos experimentais; mas os suplementados só com $0,6 \%$ cresceram mais que aqueles com $12 \%$, mostrando mais uma vez que a suplementação crescente com SMC é inversamente proporcional ao crescimento dos animais (Figura 2).

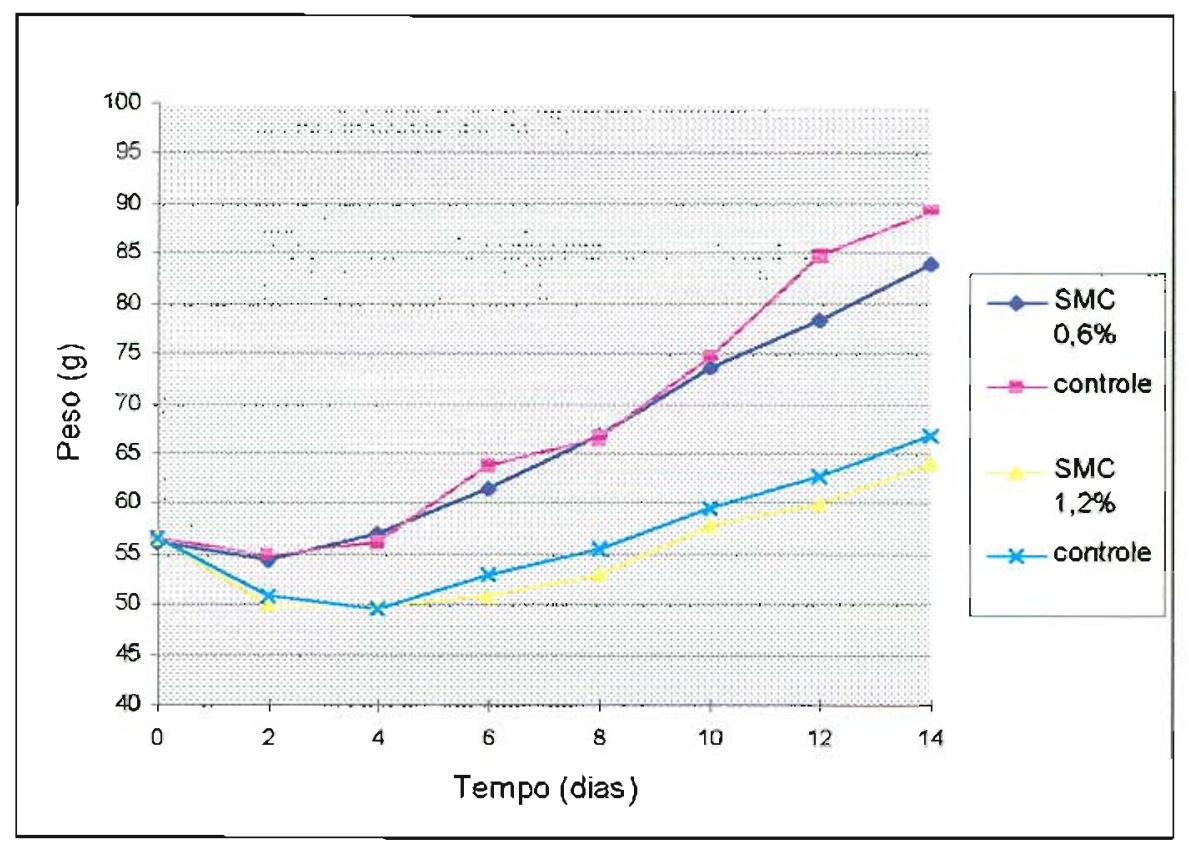

Figura 2. Curva de crescimento dos animais que receberam rações suplementadas com 0,6 e $1,2 \%$ de S-metil-L-cisteína (SMC) em comparação aos controles "paìr fed".

A análise histopatológica dos órgãos (figado, baço e rins), dos animais submetidos a estes experimentos, não mostrou alterações morfológicas, exceto um significativo aumento do peso dos rins. A administração de $180 \mathrm{mg}$ de SMC a cada dois dias, durante 14 dias, por sonda gástrica, também não provocou alterações nos órgãos, exceção feita ao aumento de peso dos rins. Ressaltamos ainda, que as análises hematológicas (hemograma, concentração de hemoglobina, \% de hematócrito e concentração de ferro no sangue periférico) foram semelhantes ao controle. Não houve indício de destruição de glóbulos vermelhos nos 
animais experimentais. Porèm, o aumento dos precursores eritróides na medula óssea, em detrimento de células maduras e da hiperplasia esplênica, embora não significativas estatisticamente, talvez possam indicar um processo de "turnover" mais rápido das hemácias.

Assim, concluimos a partir dos resultados dos nossos trabalhos, que a presença de SMC na dieta de ratos, reduziu a ingestão voluntária de ração, resultando em menor valor biológico quando comparado ao controle. Deste modo confirmamos, num primeiro momento, os trabalhos anteriores de BENEVENGA et al. (1976), FRUEDMAN \& GUMBMAN (1984) e FRIEDMAN, 1994, que a SMC tem significativo efeito sobre a ingestão de ração e o crescimento dos animais. Este último autor, em sua revisão de 1994, comentou sobre os resultados obtidos em 1094, não acrescentando dados novos.

\section{Metabolizaçāo da metionina em mamíferos}

Os resultados abtidos em nossas pesquisas anteriores, precisam de uma análise critica relativa à via de metabolização da metionina, que contribuirá para o entendimento dos efeitos adversos observados com a suplementação da SMC.

A via metabólica mais conhecida para a metionina é o processo de transsulfuração. O esquema deste processo é apresentado na Figura 3. A primeira etapa da metabolização da metionina por esta via é a formação de um composto de alta energia, a Sadenosilmetionina (AdoMet). Esta substância transfere o grupo metila ligado ao átomo de enxoffe para diversos receptores, transformando-se em S-adenosilhomocisteina. Neste processo de metilação são sintetizadas a sarcosina, creatina, lecitina, $\beta-N, N, N$. trimetillisina, (precursor da carnitina) e catecolaminas. Derivados metilados das bases púricas e pirimídicas do DNA, do RNA e de proteínas, são outros exemplos de sintese. A AdoMet é o principal doador de grupos metila do organismo (STIPANUK, 1986). Estimase que 70-95\% da AdoMet produzida participa das reaçōes de transmetilação, que são catalisadas por numerosas metiltransferases, sendo que a glicina e o guanidinoacetato, representam quantitativamente, os receptores mais importantes (GRIFFITY, 1987).

A S-adenosilhomocisteina (AdoHcy) é hidrolisada enzimaticamente em adenosina e homocisteina, sendo a enzima AdoHcy hidrolase inibida por um processo de "feedback". A homocisteina ocupa um ponto de ramificação na metabolização da metionina. Cerca da 
metade da homocisteina formada reage com a serina formando a cistationina, que é, em seguida, convertida irreversivelmente para cisteína, $\alpha$-cetobutirato e amônia, sendo o restante da homocisteina remetilado. Esta parece ser a única reação de transmetilação no organismo que ocorre independente da AdoMet. Os grupos metila, nesse caso, são originários de um mecanismo endógeno de transferência de uma unidade carbônica da serina para o tetraidrofolato, que após redução, dá origem ao 5-metiltetraidrofolato. (KRUMDIEK, 1990).

$\mathrm{O}$ átomo de enxofre disponivel na molécula da metionina determina a síntese da cisteina, enquanto o esqueleto carbônico e o grupo amina derivam da serina. Desta forma, a cisteina torna-se um aminoácido essencial quando a ingestão de metionina for insuficiente para atender às necessidades totais de enxofre.

Outra utilização do substrato Adomet estaria relacionada com a sua descarboxilação, formando a Adomet descarboxilada que é doadora de grupos aminopropil para a síntese de poliaminas, sendo assim, precursora da espermidina e da espermina.

Apesar do processo de transsulfuração ser a via mais importante e a mais conhecida, já em 1974, BENEVENGA propôs uma via metabólica alternativa para a metionina, quando esta fosse ingerida em excesso. Esta via alternativa é conhecida como via de transaminação, que independe da formação da Adomet, produzindo metabólitos tóxicos.

O esquema da transaminação é apresentado na Figura 4.

Deve-se ressaltar, entre estes produtos, a formação do metanotiol $\left(\mathrm{CH}_{3} \mathrm{SH}_{3}\right)$, substância altamente tóxica formada por esta via alternativa. A grande diferença apresentada pela reação de transaminação em relação à via de transsulfuração, é o fato da transminação preservar o grupo metila, enquanto que na reação de transsulfuração ocorre quebra da ligação carbono-enxofre. $\mathrm{O}$ grupo $\mathrm{CH}_{3}$ é transferido para uma infinidade de compostos, enquanto o enxofre é reutilizado, conforme descrito anteriormente, para a sintese de cisteina (MITCHELL \& BENEVENGA, 1978).

Além disso, sob o ponto de vista fisiológico, a reação de transaminação, não podendo produzir os grupos metila necessários para as reações vitais do organismo, não é capaz de fornecer os precursores para a sintese da cisteina e de outras moléculas biologicamente importantes. 

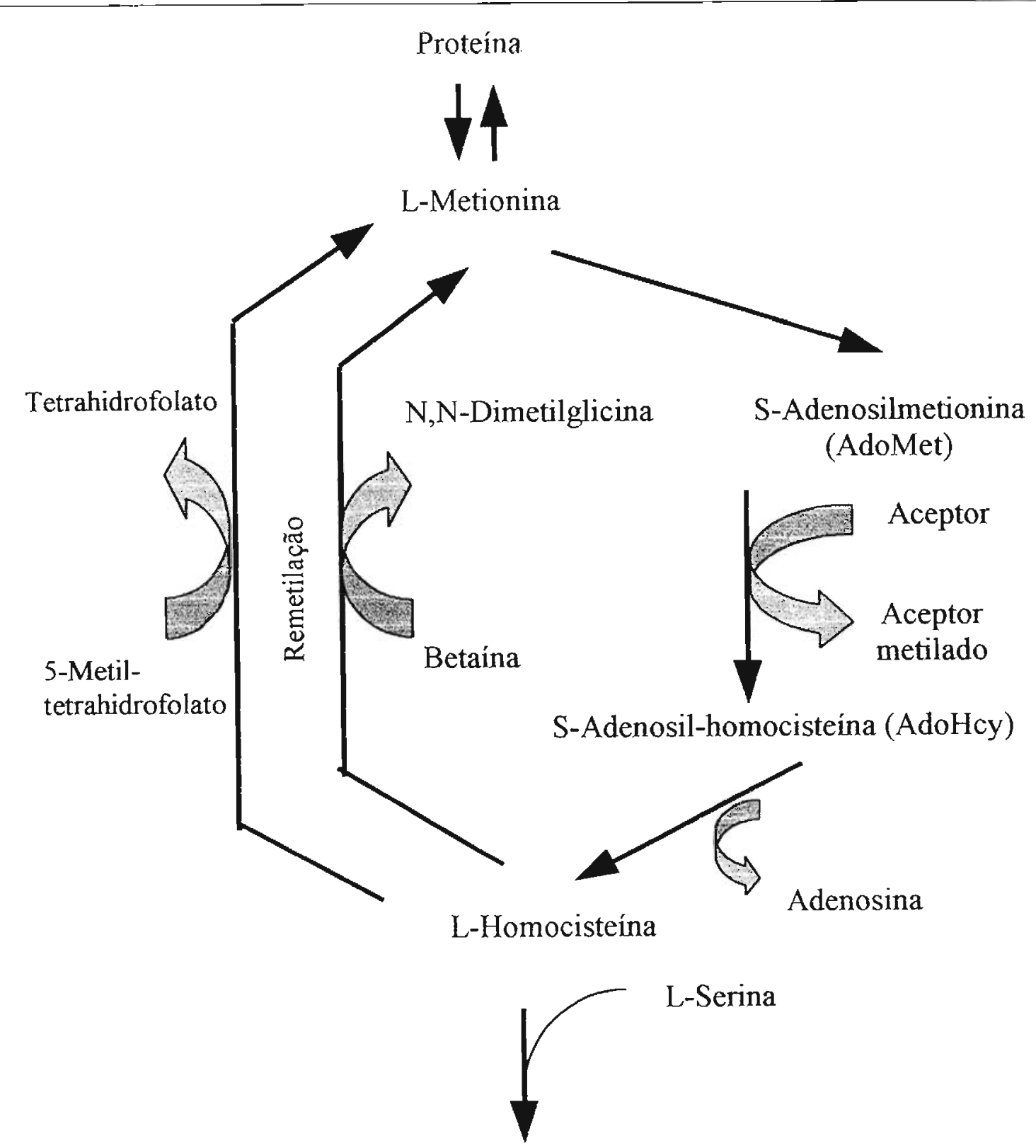

L-Serina

L-Cistationina

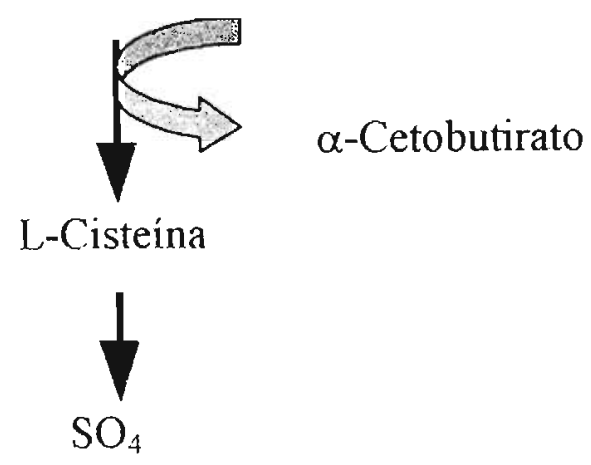

Figura 3. Metabolismo da metionina em mamíferos, via transsulfuração (Adaptado de (GAHL et al., 1987). 


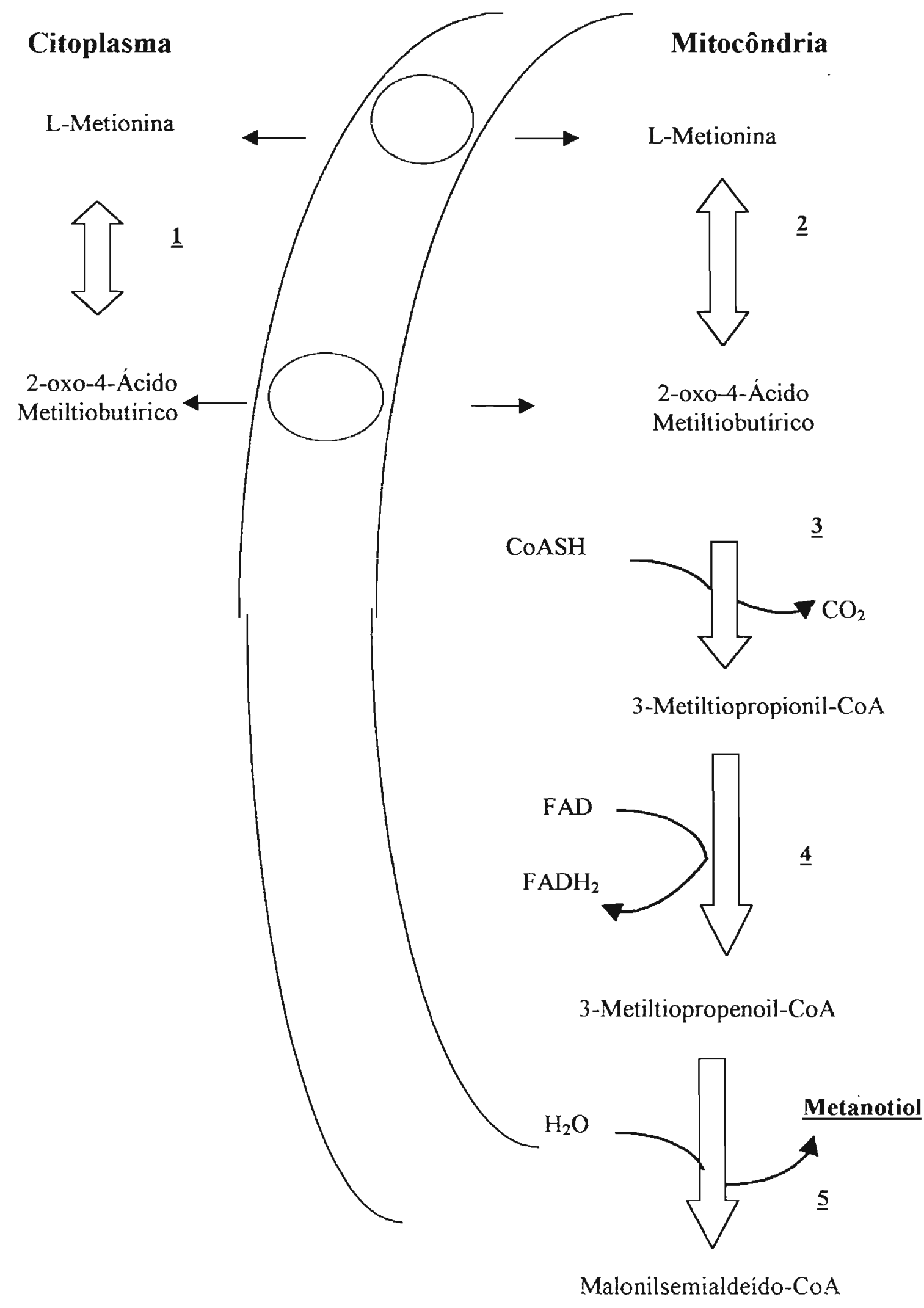

Figura 4. Metabolismo da metionina em mamíferos, via transaminação.(1) Transaminases citoplasmáticas, (2) Transaminases mitocondriais, (3) 2Oxo-ácido desidrogenase, (4) Acetil-CoA desidrogenase. (Adaptado de Scislowski \& Pichard, 1994). 


\section{Absorção e metabolização da S-metil-L-cisteína em mamíferos}

O grupo metila da SMC quando sofre metabolização, é convertido em $\mathrm{CO}_{2}$ e água no rato. Este aminoácido, quando é oferecido na dieta a animais deficientes em cisteína não é capaz de recuperá-los. Além disso, considerando-se também o fato que a incubação da SMC com uma preparação contendo a enzima metionina adenosiltransferase, não aumenta o fosfato inorgânico liberado a partir de ATP, podemos inferir que este aminoácido não deve ser ativado a um composto parecido com a S-adenosilmetionina, e neste caso, pode-se concluir que a SMC não é metabolizada pela via de transsulfuração (BENEVENGA, 1974; BENEVENGA et al., 1976; CASE \& BENEVENGA, 1976).

Atualmente, aceita-se na literatura que a SMC, proveniente dos vegetais, é metabolizada exclusivamente pela via de transaminação, enquanto que a metionina recorreria a esta via alternativa somente quando ela fosse ingerida em elevadas quantidades, o que levaria a supor uma saturação da sua via normal de transsulfuração.

A SMC é tóxica mesmo quando ofertada em quantidade reduzida, enquanto a metionina apresenta manifestações tóxicas somente quando ela é ofertada em grandes quantidades. Nestas condições, a toxicidade de ambas torna-se semelhante, fato este também esperado para o peptídeo $\gamma$-glutamil-SMC.

Acredita-se que o efeito tóxico seja devido à ação do metanotiol, que corresponde a um dos metabólitos do grupo metiltio presente nas duas moléculas, produzido durante a reação de transaminação. As proporções relativas na reação de metabolização de cada uma destas substâncias intermedíarias é variável, dependendo da atividade das enzimas envolvidas na degradação.

Estudos relacionados com a absorção a nível intestinal da SMC e da $\gamma$-glutamilSMC e sua metabolização, poderão trazer informações que permitam uma melhor avaliação da importância dos possiveis efeitos fisiológicos provocados pelos produtos de degradação do grupo metiltio. Uma reduzida taxa de absorção a nível intestinal da SMC e da $\gamma$ glutamil-SMC poderia proteger o organismo dos efeitos deletérios destas substâncias

O processo de utilização das proteínas da dieta envolve, como passo inicial, sua digestão no lúmen intestinal a fim de gerar produtos de tamanhos menores passiveis de serem absorvidos pelo enterócito. O epitélio intestinal possui um eficiente sistema de transporte capaz de absorver estes compostos. Na Figura 5, mostramos, esquematicamente, 
a assimilação de proteínas no intestino delgado Os produtos resultantes da açào de proteases e peptidases gástricas e pancreáticas, geralmente aminoácidos livres e pequenos peptideos de três a seis residuos de aminoácidos, sofrem hidrólise por uma grande variedade de peptidases presentes na bordadura em escova da membrana do epitélio intestinal.

Os aminoácidos livres são absorvidos pelo enterócito por sistemas de transporte específicos. Os peptídeos pequenos, principalmente aqueles contendo dois ou três aminoácidos, são transportados intactos pela membrana usando um transporte exclusivo para peptídeos, enquanto o transporte de tetrapeptideos ocorre em quantidades infimas

Em seguida, no interior do enterócito, a maioria dos peptídeos é hidrolisada por peptidases citossólicas altamente ativas, gerando então os aminoȧcidos livres.

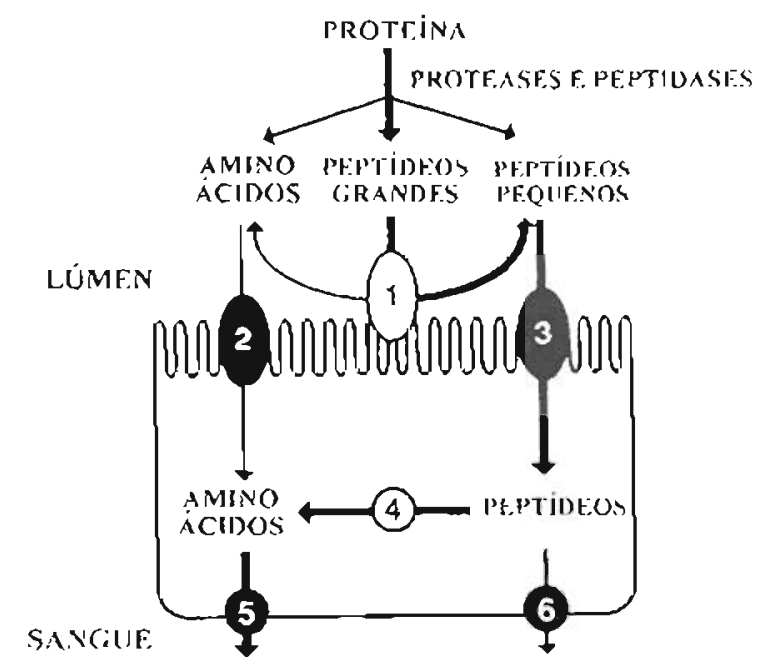

Figura 5. Digestão e absorção de proteínas no intestino delgado. I - Peptidases da bordadura em escova; 2 - Sistemas de transporte de aminoácidos da bordadura em escova; 3 - Sistemas de transporte de peptideos da bordadura em escova; 4 Proteases citoplasmáticas; 5 - Sistema basolateral de transporte de aminoácidos: 6 - Sistema basolateral de transporte de peptideos. (Ganapathy el al., 199f)

Aceita-se a existência de sistemas de transporte diferentes para a absorção de aminoácidos livres e peptídeos, havendo provas que confirmam esta assertiva (DAS \& RADHAKRISHNAN, 1976; MATTHEWS \& PAYNE, 1980) Um exemplo desta evidência, seria a não competição entre peptideos e aminoácidos livres durante a sua absorção. O transporte de aminoácidos através de membranas celulares é um assunto bastante complexo, devido à existência de mütiplos e intrincados sistemas de iransporte. 
Os aminoácidos diferem entre si quanto à estrutura química, o que determina o tamanho, lipofilicidade e carga elétrica da molécula. Assim, devido a essas diferenças físicoquímicas, um único sistema de transporte via enterócito, seria certamente insuficiente para absorver todos os aminoácidos. A Tabela 3, ilustra bem o que dissemos e mostra os sete sistemas de transporte de aminoácidos conhecidos, e os classifica de acordo com os respectivos substratos e dependência de gradiente de íns. O transporte apresentado pelo enterócito é do tipo mediado, podendo ser por difusão facilitada ou transporte ativo (GANAPATHY, et al., 1994).

Tabela 3. Classificação dos sistemas de transporte de aminoácidos na bordadura em escova da membrana das células do intestino delgado.

\begin{tabular}{|c|c|c|c|}
\hline $\begin{array}{l}\text { Sistema de } \\
\text { Transporte }\end{array}$ & Substratos & $\begin{array}{l}\text { Dependência de um } \\
\text { gradiente de } \mathrm{Na}^{+}\end{array}$ & $\begin{array}{l}\text { Envolvimento } \\
\text { de outros ions }\end{array}$ \\
\hline $\mathrm{B}$ & $\alpha$-Aminoácidos dipolares & $\mathrm{Sim}$ & Nenhum \\
\hline \multirow[t]{2}{*}{$\mathrm{B}^{0,+}$} & $\alpha$-Aminoácidos dipolares & $\operatorname{Sim}$ & Nenhum \\
\hline & $\begin{array}{l}\text { Aminoácidos básicos } \\
\text { Cistina }\end{array}$ & & \\
\hline \multirow[t]{3}{*}{$b^{0,+}$} & $\alpha$-Aminoácidos dipolares & Não & Nenhum \\
\hline & Aminoácidos básicos & & \\
\hline & Cistina & & \\
\hline$y^{+}$ & Aminoácidos básicos & Não & Nenhum \\
\hline IMINO & Iminoácidos & Sim & $\mathrm{Cl}^{-}$ \\
\hline$\beta$ & $\beta$-Aminoácidos & $\operatorname{Sim}$ & $\mathrm{Cl}^{-}$ \\
\hline$X_{A G}^{-}$ & Aminoácidos ácidos & $\operatorname{Sim}$ & $\mathrm{K}^{+}$ \\
\hline
\end{tabular}

Ganapathy et al., 1994.

A membrana basolateral dos enterócitos, também possui sistemas de transporte específicos e distintos para aminoácidos livres e peptídeos. É interessante notar que, muito embora os produtos da digestão protéica que entram no enterócito sejam formados principalmente por di- e tripeptídeos, os produtos que efetivamente passam para a corrente sangüinea são constituídos principalmente por aminoácidos livres. A quantidade de 
peptídeos que entram na circulação sangüinea na forma intacta, é inferior à 10\% em relação aos aminoácidos (GARDNER et al., 1983), embora ALPERS (1986) afirme que a absorção de di- e tripeptídeos ainda não está elucidada, mas poderia atingir $25 \%$ em relação ao total de aminoácidos absorvidos.

Em relação ao processo de absorção intestinal de $\gamma$-glutamil peptídeos pouco se conhece. A glutationa (GSH), um tripeptideo constituído de ácido glutâmico, cisteína e glicina, possue uma ligação amida com o grupo carboxila da posição $\gamma$, assemelhando-se de certa forma, estruturalmente e em termos de polaridade, aos demais $\gamma$-dipeptideos sulfurados. A GSH pode ser transportada por um sistema de transporte exclusivo presente nos dois polos do enterócito, permitindo a sua passagem direta para o sangue e vice-versa, através de um sistema de transporte "transepitelial", ou então, ser hidrolisado pela ação da $\gamma$-glutamil transpeptidase ( $\gamma$-GT) (VINCENZINI et al., 1992). A GSH encontra-se presente em praticamente todas as células dos mamiferos, constituindo aproximadamente $90 \%$ dos compostos sulfurados não-protéicos. Este fato justifica a existência de uma enzima, a $\gamma$-GT que atua tanto na síntese como na degradação dessa molécula, transferindo o ácido glutâmico para um outro aceptor. A GSH é considerada o antioxidante intracelular mais importante, sugerindo-se um papel essencial na inativação de oxidantes biológicos, tais como hidroperóxidos, radicais livres e outros, atuando também na destoxificação de substâncias xenobióticas e cancerígenas. Esta atividade antioxidante ocorre pela alternância entre a forma tiol reduzida (GSH) e a forma oxidada (GSSG), devido à ligação dos dois peptídeos por uma ponte de dissulfeto (HENDRICH \& PITOT, 1987).

Entretanto, parece que o sistema de absorção para a glutationa não interage com outros $\gamma$-glutamil peptídeos e nem com di- e tripeptídeos, cuja ligação peptídica ocorra na posição $\alpha$ (VINCENZINI et al., 1992).

Assim, em relação à $\gamma$-glutamil-SMC, existem muitas dúvidas quanto à sua absorção. Ela seria hidrolisada por alguma peptidase no interior do enterócito, liberando os dois aminoácidos, ou ocorreria o seu transporte através do enterócito, atingindo a corrente sangüinea na forma intacta.

Alguns trabalhos apontam vagamente em relação à hidrólise, embora não exista na literatura, até o momento, nenhum trabalho recente relativo à absorção da $\gamma$-glutamil-SMC em particular. A enzima $\gamma$-GT faria a transposição do ácido glutâmico para um outro 
aceptor, liberando a SMC na sua forma livre que então seria transportada para a corrente sangüínea (GARVEY et al., 1976; HUGHEY \& CURTHOYS, 1976; CURTHOYS \& HUGHEY, 1979).

Com a finalidade de contribuir para a elucidação do processo de absorção deste peptídeo, realizamos experimentos de absorção "in vivo", que representam os primeiros ensaios desta natureza descritos na literatura para o peptídeo $\gamma$-glutamil-SMC (PADOVESE \& LANFER MARQUEZ, 1998; PADOVESE et al. aceito para publicação). Os ensaios foram realizados em ratos, administrando-se quantidades equimolares dos aminoácidos metionina, SMC e do peptídeo $\gamma$-glutamil-SMC, previamente isolado e purificado, através de sonda gástrica. A ingestão do peptídeo ocasionou o aparecimento exclusivamente de SMC no sangue periférico, apoiando a hipótese da hidrólise do peptideo por uma enzima ligada a bordadura em escova, ou então presente no citossol do enterócito. O peptídeo intacto não foi detectado no sangue.

Comparando-se a metionina com a SMC, observamos que a SMC apresenta um perfil de absorção e de metabolização diferente da metionina: a metionina é absorvida rapidamente, atingindo um valor máximo no sangue periférico, em aproximadamente 30 minutos após a sua administração gástrica, enquanto a ingestão de SMC sintética possui um pico de absorção máximo, uma hora após a administração. Não sabemos ainda, se os dois aminoácidos, a metionina e a SMC, apesar de serem análogos estruturais, diferindo em apenas um grupo $\mathrm{CH}_{2}$, são absorvidos pela membrana do enterócito, compartilhando o mesmo sistema de transporte

Em relação à absorção do peptídeo $\gamma$-glutamil-SMC, este retarda o aparecimento da SMC no sangue. O pico de absorção se deu apenas três horas após a administração e a partir daí, o decaimento foi lento, assemelhando-se ao decaimento da SMC sintética. Para ilustrar o que dissemos, apresentamos as Figuras 6, 7 e 8

Estudando-se a fase de decaimento no sangue, da metionina e da SMC, observamos que a queda na concentração da metionina é bem mais acentuada do que a da SMC. Este dados indicam que estes dois aminoácidos são metabolizados por vias distintas: transsulfuração para a metionina e transaminação para a SMC. Observamos ainda que a transaminação da SMC ocorre muito mais lentamente do que a transsulfuração da 
metionina. Após três horas, a metabolização da SMC foi só de $30-40 \%$, contra $70 \%$ ou mais da metionina.

Reunindo os resultados dos nossos experimentos com as escassas informações da literatura, afirmamos que a redução significativa na ingestão voluntária de ração pelos animais, deve estar relacionada com algum mecanismo de defesa do seu organismo contra os efeitos deletérios dos produtos tóxicos, dimetil-dissulfeto e metanotiol, produzidos a partir da SMC. Entretanto, devido à lenta transformação da SMC em metanotiol e seus metabólitos, através da via de transaminação, isto impediria que estes compostos atingissem concentrações elevadas na corrente sanguínea, e provocassem efeitos danosos mais pronunciados.

Contudo, o mecanismo intrínseco, através do qual a metionina, a SMC, a $\gamma$-glutamilSMC e os seus produtos derivados exercem suas ações tóxicas em humanos e em animais, ainda não é totalmente compreendido. 
Figura 6. Concentrą̧ão de metionina ( $\mu$ moles $/ \mathrm{mL}$ ) no sangue periférico após administraç̃̃o de $66 \mu$ moles $(9,8$ $\mathrm{mg}$ ) de metionina por sonda gástrica.
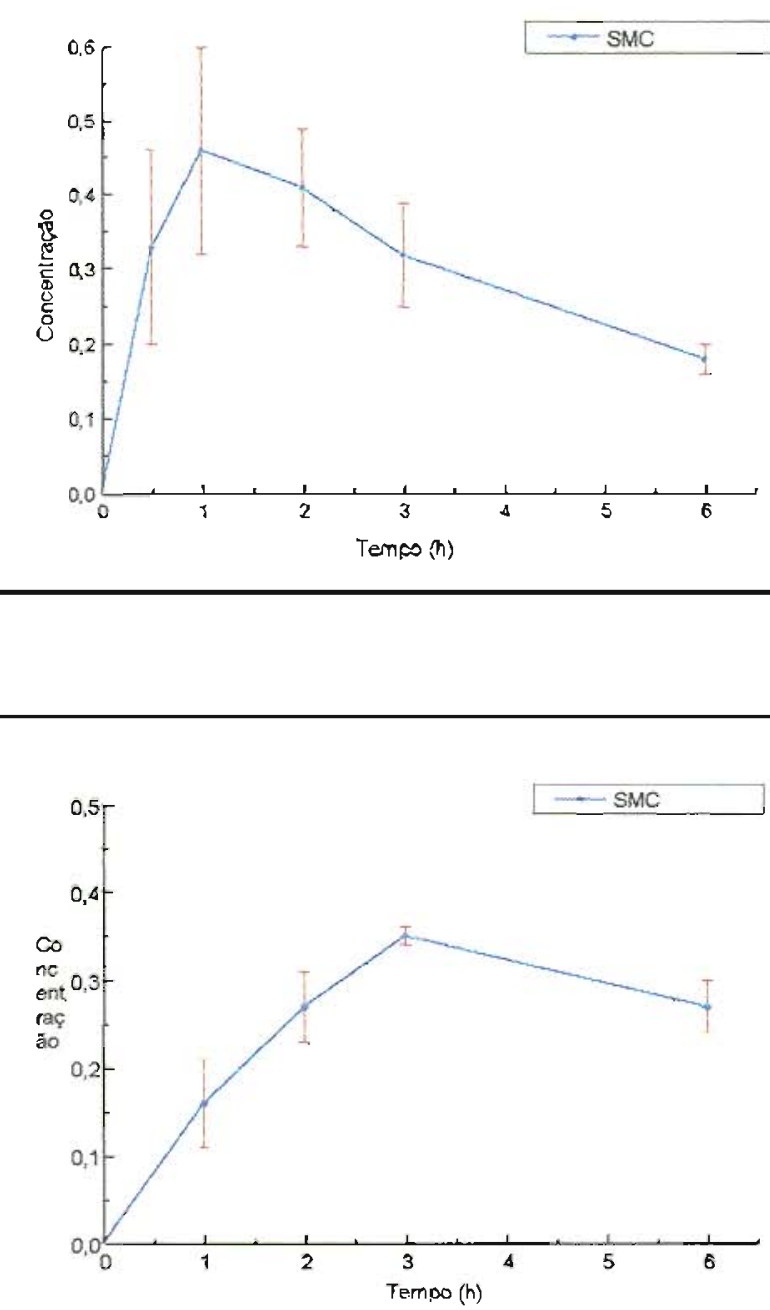

Figura 7. Concentração de Smetil-L-cisteina ( $\mu$ moles $/ \mathrm{mL}$ ) no sangue periférico após administração de 66 umoles $(8,9$ $\mathrm{mg}$ ) de SMC por sonda gástrica.

Figura 8. Concentração de Smetil-L-cisteina ( $\mu$ moles $/ \mathrm{mL}$ ) no sangue periférico após administração de 66 umoles $(17,4 \mathrm{mg})$ do peptídeo no extrato bruto por sonda gástrica. 


\section{Efeitos tóxicos da metionina e da S-metil-L-cisteína em mamíferos}

A metionina é o aminoácido essencial mais tóxico, quando ingerido em quantidades três a quatro vezes superiores às necessidades fisiológicas $(0,2 \%$ nas dietas de caseína com reduzido teor protéico) (BENEVENGA \& STEELE, 1984). Os efeitos manifestados, nestas condições, incluem uma significativa redução na ingestão voluntária da ração, cessando o crescimento dos animais e ocorrendo aumento e escurecimento do baço. Quimica- e histologicamente observou-se deposição aumentada de ferro nos tecidos (figado, baço e medula), sem nenhuma evidência de maior absorção de ferro. Ocorrendo ainda, hiperplasia de eritrócitos, hemossiderose no baço, e maior "turnover" dos eritrócitos. A hemólise explica a deposição de ferro no baço e no figado e como conseqüência, a instalação de um quadro de anemia hemolitica. Efeitos semelhantes são observados após administração de 3-metiltiopropionato, o que não ocorre após a ingestão de homocisteina, cistationina, cisteína e homocistina, demonstrando que a via de transaminação, através de seus metabólitos intermédiários, é a responsável pelos danos causados (BENEVENGA et al., 1976; CASE \& BENEVENGA, 1976; FINKELSTEIN \& BENEVENGA, 1984, 1986).

O metanotiol, produto do metabolismo destes dois aminoácidos, é considerado um gás tóxico e pode levar a um estado de coma reversivel, mesmo em baixas concentrações. Segundo ZIEVE et al. (1974) $70 \mu$ moles de metanotiol/L de ar é uma dose na qual 50\% dos ratos entram em estado de coma. Quando o metanotiol é injetado via intraperitoneal, a dose que provoca coma em $50 \%$ dos ratos é 55 umoles, para animais com $250 \mathrm{~g}$. (BLOM et al., 1990).

Em tese, o metanotiol, um dos intermediários da transaminação, pode causar danos quando se liga diretamente à membrana do eritrócito, através do grupo $\mathrm{SH}$ da cisteína, ou inibindo enzimas que são importantes na prevenção de reações oxidativas. Foi observada significativa redução da atividade da citocromo-c-oxidase e da eritrócito oxidase (degradam $\mathrm{H}_{2} \mathrm{O}_{2}$ e $\mathrm{O}_{2}{ }^{-}$, que sabidamente danificam a membrana), embora os autores tenham constatado que a inibição destas enzimas não foi responsável pelo dano à mucosa. (FINKELSTEIN \& BENEVENGA, 1986).

O metanotiol é um gás muito reativo, sendo detectado com dificuldade nos fluidos biológicos. Quando incubado com sangue, grande parte reage com os eritrócitos, havendo 
quebra da ligação carbono-enxofre, ocorrendo então uma oxidação do enxofre para sulfito ou sulfato e uma oxidação do carbono para ácido fórmico. Estas substâncias são eliminadas finalmente na forma de sulfato e $\mathrm{CO}_{2}$, respectivamente pela via renal e pulmonar (BLOM \& TANGERMAN, 1988). Pode ocorrer também a formação de dimetil-sulfeto $\left(\mathrm{CH}_{3} \mathrm{SCH}_{3}\right)$, de proteina-S-S- $\mathrm{CH}_{3}$ (um dissulfeto misto de proteinas do sangue e metanotiol) e de X-S-S$\mathrm{CH} 3$ (um dissulfeto misto de metanotiol e um outro tiol cujo componente $\mathrm{X}$ é desconhecido) (BLOM et al., 1990, 1991; SCISLOWSKI \& PICKARD, 1994).

Alguns trabalhos sustentam a hipótese de que o metanotiol poderia ser a causa de encefalopatia hepática (CHALLENGER \& WALSHE, 1955; ZIEVE et al., 1974, ZIEVE, 1981; BLOM et al., 1989). Porém, estudos mais aprofundados não confirmaram esta suspeita e evidenciaram que o metanotiol não é importante na patogenia da doença encefalopatia hepática. Nesta patologia ocorre uma diminuição da conversão da metionina, tanto pela via de transsulfuração como pela via de transaminação, devido ao decréscimo da atividade enzimática em doentes hepáticos (ALMARDINI et al., 1998; BLOM et al., 1990, 1991)

Um interessante estudo foi elaborado com um paciene de 31 anos de idade, que apresentava deficiência genética da enzima metionina adenosiltransferase (MAT). Apesar da hipermetioninemia crônica $(<1 \mathrm{mM})$ este paciente era clinicamente saudável, contrariando a expectativa em relação à toxicidade da metionina. Os autores concluiram que a metabolização do excesso da metionina talvez fosse realizada pela MAT extrahepática, sugerindo ainda que a MAT hepática e a extra-hepática estariam sob controle genético independente. Esta independência estaria justificada porque a atividade enzimática é extremamente essencial para os processos de metilação do DNA e de outras substâncias importantes para a manutenção vital (GAHL et al., 1987).

Outro trabalho realizado com 4 crianças que apresentavam hipermetioninemia persistente por deficiência hepática da MAT, mostrou que estas estavam também clinicamente sadias. Nestas crianças foi encontrado pela microscopia eletrônica do hepatócito: aumento do retículo endoplasmático liso, decréscimo do retículo plasmático rugoso, aumento dos lissosomos e danos diversos das membranas das mitocôndrias. A explicação apresentada pelos autores foi que a MAT extra-hepática teria assumido parcialmente a degradação da metionina pela via de transsulfuração (GAULL et al., 1981). 
Em outro estudo com indivíduos normais submetidos a uma dose de $0,1 \mathrm{~g} / \mathrm{kg}$ de metionina, BLOM e seus colaboradores (1989) concluiram que a contribuição da transaminação no catabolismo da metionina foi pequena, embora tenha sido observado um aumento significativo dos metabólitos desta via, mas diversos pesquisadores afirmam que a transaminação pode representar $20 \%$ de todo catabolismo da metionina (LIVESEY, 1984; GAHL et al., 1987, GAHL et al., 1988).

SCISLOWSKI \& PICKARD (1994), estudando a produção de metanotiol a partir de metionira em mitocôndrias de figado de ratos, concluiram que a transaminação desempenha um importante papel na degradação da metionina quando esta se encontra em excesso, embora os autores reconheçam que as suas consequências fisiologicas ainda necessitam de maior investigação.

O conjunto de todas estas informações dos autores na literatura, mostra que o objetivo de alcançar o entendimento dos mecanismos intrínsecos da toxicidade da SMC, não foi conseguido até o momento. Os ensaios realizados em nosso laboratório nos permitem afirmar que a SMC administrada aos animais em crescimento, não pode ser considerada inócua devido ao reduzido desenvolvimento dos animais, aliado à recusa de ingerir a rą̧ão que continha SMC; indicios de aumento dos precursores eritróides na medula óssea com um discreto desvio à esquerd́a da série leucocitária, indicando um maior "tumover" das hemácias e o início de um processo inflamatório, são compativeis com os efeitos tóxicos conhecidos do grupo metiltio. Assim o entendimento dos mecanismos intrinsecos continua sendo um dos nossos desafios.

\section{Funçāo e metabolização de aminoácidos e peptideos $\gamma$-glutamil sulfurados em vegetais}

Além dos vinte aminoácidos protéicos, mais de 400 outros aminoácidos naturais podem ser encontrados nos vegetais, denominados genericamente de aminoácidos nãoprotéicos. Juntamente com a identificação dessas substâncias, foram encontrados também os $\gamma$-glutamil peptideos onde o aminoácido, protéico ou não, encontra-se ligado ao ácido glutâmico na posição gama Somados aos 20 aminoácidos protëicos, exceção feita à prolina, foram encontrados peptídeos com inúmeros aminoácidos não protéicos. Este 
número está crescendo ano a ano, à medida que novas espécies são analisadas sistematicamente (BELL, 1971; ROSENTHAL \& BELL, 1979; LI et al., 1996).

O número de $\gamma$-glutamil peptideos descritos na literatura já ultrapassa 80 , de acordo com a revisão mais recente e completa realizada por KASAI \& LARSEN (1980). Destes, mais de 25 peptideos possuem enxofre na sua molécula, sendo representados principalmente pela $\gamma$-glutamil-metionina, pela $\gamma$-glutamil-SMC e pelos seus respectivos sulfóxidos

Na família Leguminosae, os peptídeos sulfurados vem sendo estudados, nas sementes comestiveis e particularmente naquelas de maior importância econômica, visando conhecer melhor os seus constituintes e a participação destas substâncias sulfuradas sob ponto de vista nutricional e/ou tóxicológico

A função fisiológica dessas substâncias nos vegetais, não está completamente esclarecida. Ainda não foi possível evidenciar um papel comum a todos os $\gamma$-glutamil derivados nas plantas, existindo a possibilidade de que alguns possam ter papéis especificos

Na familia Alliaceae, os $\gamma$-glutamil peptídeos assumem importância como precursores de compostos voláteis organossulfurados, formados pela degradaçào enzimática destes peptídeos (LANCASTER \& KELLY, 1983, LANCASTER \& SHAW, 1991; MUTSCH-ECKNER et al., 1992; CHIN \& LINDSAY, 1994).

Já nas Brássicas, pertencentes à família das Cmiciferas, o estudo dessas substâncias sulfuradas é motivado pelo uso de folhas desses vegetais na alimentação de gado e pela ação tóxica que exercem sobre ruminantes. Outro aspecto importante é o estudo da biossintese dos compostos sulfurados voláteis, por causarem "off-flavors" em vegetais dessa familia (GRIFFITHS et al., 1994).

Assim, várias hipóteses foram propostas até agora para explicar a função das substâncias sulfuradas nos vegetais. Alguns autores relatam que o sulfóxido de SMC, presente nas Brássicas, é o precursor do metilmetanotiossulfinato, uma substância com pronunciada atividade antibacteriana, servindo de defesa para o vegetal (KYUNG \& FLEMING, 1994). Entretanto, uma das hipóteses mais aceitas atribui aos $\gamma$-glutamil peptídeos papel de armazenamento de $\mathrm{N}$ e $\mathrm{S}$, aceitando-se o fato, destas substâncias 
desaparecerem durante a germinação das sementes de leguminosas e de bulbos de alho e de cebola (KASAI et al., 1982; FENWICK \& HANLEY, 1985; CECI et al., 1992).

A hipótese do armazenamento de $\mathrm{N}$ e de $\mathrm{S}$ nos estimulou a realizar um experimento voltado para o monitoramento do perfil de $\gamma$-glutamil peptideos e de aminoácidos livres durante a germinação do feijão comum, variedade Carioca (REIS GIADA, 1995).

Foi utilizado o procedimento descrito por WU \& WALL (1980). As sementes foram pesadas, lavadas com água e posteriormente com solução de formaldeido $0,2 \%$ para desinfeç̧ão, sendo então divididas em 18 grupos. Cada grupo continha 100 sementes que foram espalhadas em placa de Petri, sendo mantidas durante 5 dias à temperatura ambiente $\left(27-29^{\circ} \mathrm{C}\right)$ e à luz natural, para germinar. Diariamente, durante o ensaio de cinco dias, foram retiradas amostras com a finalidade de realizar o controle da umidade e concentração protéica das mesmas, bem como para a extração e análise da fração não-protéica. Interrompeu-se o ensaio da germinação no $5^{\circ}$ dia devido à elevada temperatura ambiente que acelerou demasiadamente o processo de germinação. Durante este período de 5 dias, ocorreu uma perda do peso das sementes de aproximadamente $12 \%$, enquanto o teor de proteina teve um acréscimo de 19,6\%. Em termos absolutos, o aumento do teor protéico nas sementes foi de $7,6 \%$.

Estudando o comportamento da $\gamma$-glutamil-SMC, observamos um decréscimo do dipeptídeo durante a germinação, analisando-se o extrato nitrogenado não protéico (Figuras 9 e 10). Durante a germinação das sementes ocorteu um decréscimo do peso das mesmas, aumento do teor de proteina, decréscimo do peptideo não protéico, (sem ocorrer aumento dos produtos da sua hidrólise: SMC livre e ácido glutâmico). Esta sequência de acontecimentos só pode ser explicada se admitirmos que ser esse dipeptídeo uma substância de reserva da semente para a sua germinação. 


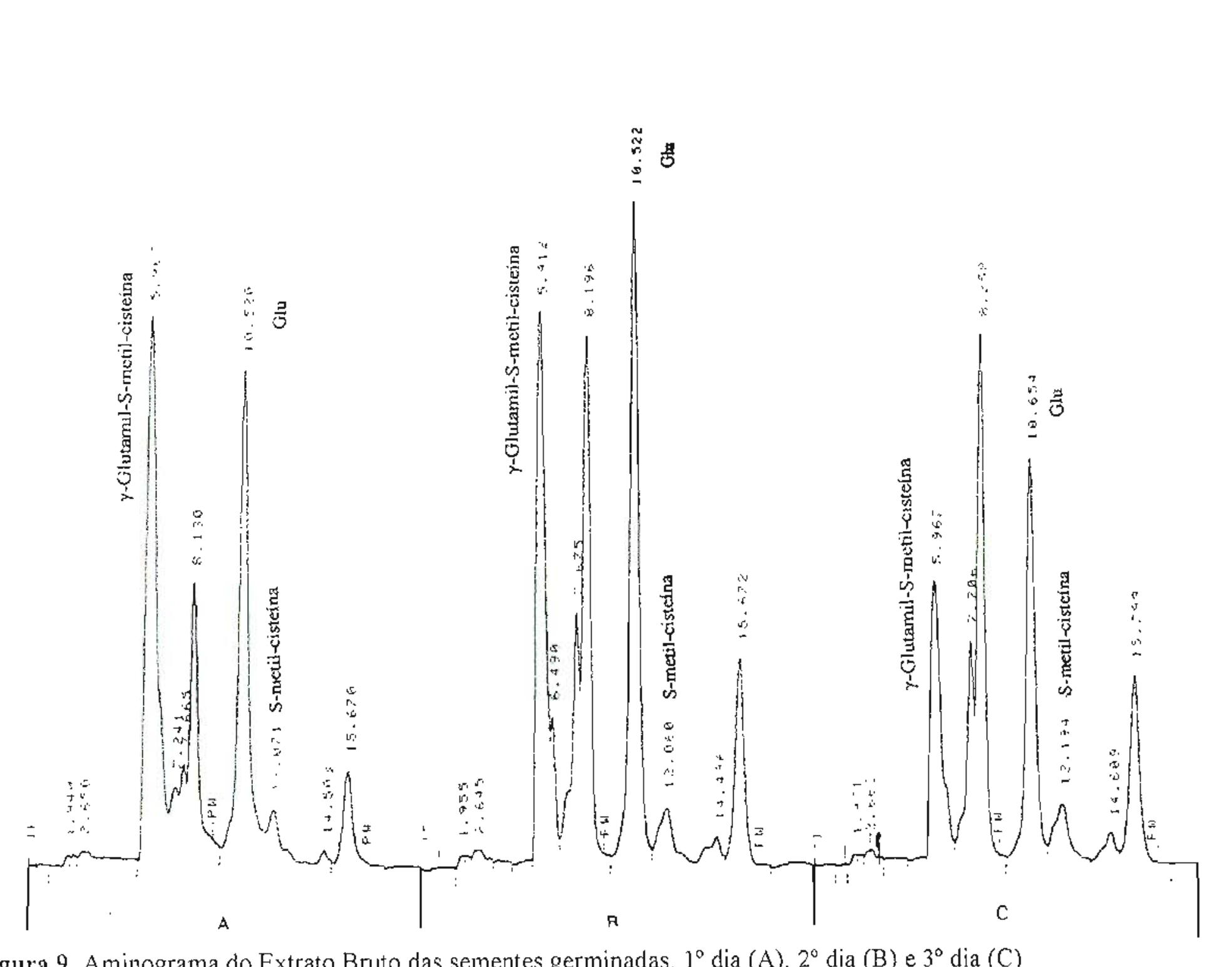




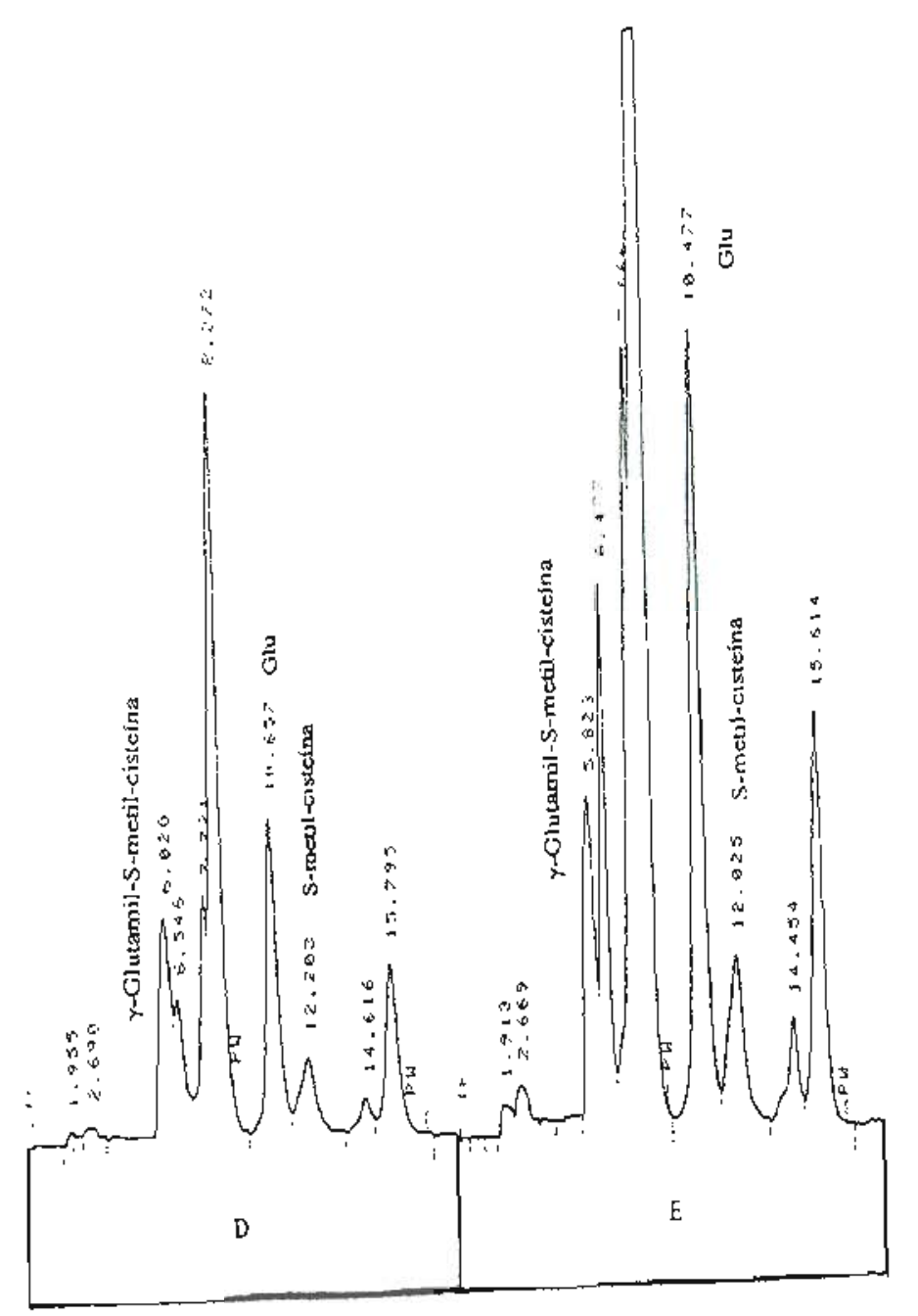

Figura 10. Aminograma do Extrato Bruto das sementes germinadas $4^{\circ}$ dia (D) e $5^{\circ}$ dia (E) 
Assim, acreditamos que, ao menos uma das funções básicas do peptideo $\gamma$-glutamilSMC, seria desempenhar uma ação de reserva do bulbo ou da semente para os processos que exigem uma maior atividade metabólica.

Uma outra hipótese formulada seria a sintese de peptídeos, que é uma forma de tornar os aminoácidos livres em excesso menos tóxicos, especialmente se houver dificuldade em inseri-los em proteinas (BENEVENGA, 1974).

Estes dipeptídeos poderiam atuar ainda, segundo alguns autores, no transporte de aminoácidos através da membrana celular, num processo semelhante ao proposto para animais e microrganismos, sugerindo-se a participação da enzima $\gamma$-GT (KASAI \& LARSEN, 1980). Mais recentemente aventou-se a hipótese de certos intermediários do metabolismo dos $\gamma$-glutamil peptídeos atuarem no processo de regulação da assimilação do $\mathrm{SO}_{4}$ pela planta (KRAUSS \& SCHMIDT, 1987).

Além disso, os aminoácidos nāo protéicos parecem também exercer uma função de defesa do vegetal contra predadores, do mesmo modo como o verificado com outros aminoácidos análogos aos aminoácidos protéicos, que se mostraram tóxicos para insetos (ROSENTHAL \& BELL, 1979; BIRCH et al., 1986)

Assim, diversos aminoácidos pertencentes à fração nitrogenada não protéica de vegetais, apresentam forte interação metabólica tóxica quando são ingeridos por animais. Esta toxicidade parece ser causada devido à sua semelhança na forma e tamanho molecular, em relação a um aminoácido protéico em particular. Nestas circunstâncias, pode-se esperar que o comportamento tóxico destes compostos esteja relacionado a uma ação antagônica contra certas reaçōes básicas ou a uma inibição competitiva de enzimas especificas, levando a sua possível incorporação em proteinas, o que acarretaria a perda da sua função especifica (EVANS \& BANDEMER, 1967; FOWDEN \& PEA, 1979, REESE, 1979)

Na Figura 11, apresentamos alguns exemplos de aminoácidos e seus respectivos análogos, que possuem atividade tóxica. A canavanina é um aminoácido não protéico encontrado nas plantas pertencentes à subfamília l'apılionoideae, em especial, nas espécies do gênero Canavalia. Este aminoácido é considerado um análogo da arginina, sendo 
rapidamente incorporado nas proteinas da maioria dos insetos, quando são ingeridas, atuando como inibidor competitivo no metabolismo da arginina, inibindo então a reprodução e a metamorfose dos insetos. Alguns estudos sugerem que a canavanina e as fitohemaglutininas podem ser as responsáveis pela resistência apresentada pelas sementes de leguminosas contra à infestação por Callosobruchus ssp. Entretanto no homem, a ação tóxica da canavanina pode ser diminuida através da ingestão de lisina que atua como antagonista da arginina.

Em relação à mimosina, um análogo da tirosina, os principais efeitos colaterais quando ingerido em excesso, são representados por: perda de pelos em equinos e suínos, alterações no processo reprodutivo nos ratos, gerando fetos com malformacões múltiplas e redução na produção de ovos em galináceos. Outro exemplo é a selenometionina, que pode ser incorporada em proteínas, no lugar da metionina.<smiles>N=C(N)NCCCC(N)C(=O)O</smiles>

Arginina<smiles>NC(Cc1ccc(O)cc1)C(=O)O</smiles>

Tirosina<smiles>CSCCC(N)C(=O)O</smiles>

Metionina<smiles>N=C(N)NOCCC(N)C(=O)O</smiles><smiles>Cn1ccc(=O)c(O)c1</smiles>

Mirnosina<smiles>CSCCC(N)C(=O)O</smiles>

Selenometionina

Figura 11. Análogos de aminoácidos protéicos que apresentam atividade tóxica (Rosenthal \& Bell, 1979; D'Mello, 1992) 
As alteraçōes funcionais dos peptídeos formados com selenometionina, no lugar de metionina, são suficientes para causar mau funcionamento das enzimas e de outras proteinas importantes para o organismo (ROSENTHAL \& BELL, 1979; D'MELLO, 1992). Todavia, as sementes das leguminosas que contêm a y-glutamil-SMC, como por exemplo o fejjão comum, não são poupadas pelos insetos que costumam atacar estes grãos, indicando que este peptídeo não seria tóxico para eles (SHEPARD et al., 1983)

Devido a ampla distribuição dos aminoácidos não protéicos e dos seus respectivos $\gamma$-glutamil peptídeos, em pelo menos 21 familias de vegetais, sugere-se que estas substâncias desempenham funções muito além das de defesa da planta contra predadores, acreditando-se que exerçam um papel importante no metabolismo secundário dos vegetais

\section{Biossintese e metabolização de compostos organossulfurados em vegetais}

A biossíntese dos compostos organossulfurados é complexa, existindo um enorme leque dessas substâncias nos vegetais (GIOVANELLI et al., 1980). As transformaçôes que ocorrem até culminar nos peptídeos $\gamma$-glutamil sulfurados, foram estudadas nos vegetais da familia Alliaceae, particularmente, analisando-se o alho (Allizm spp) marcado com ${ }^{35} \mathrm{SO}_{4}{ }^{2 .}$ Este estudo permitiu traçar a via biossintética desta família (BLOCK, 1992). O esquema da biogênese é apresentado na Figura 12 


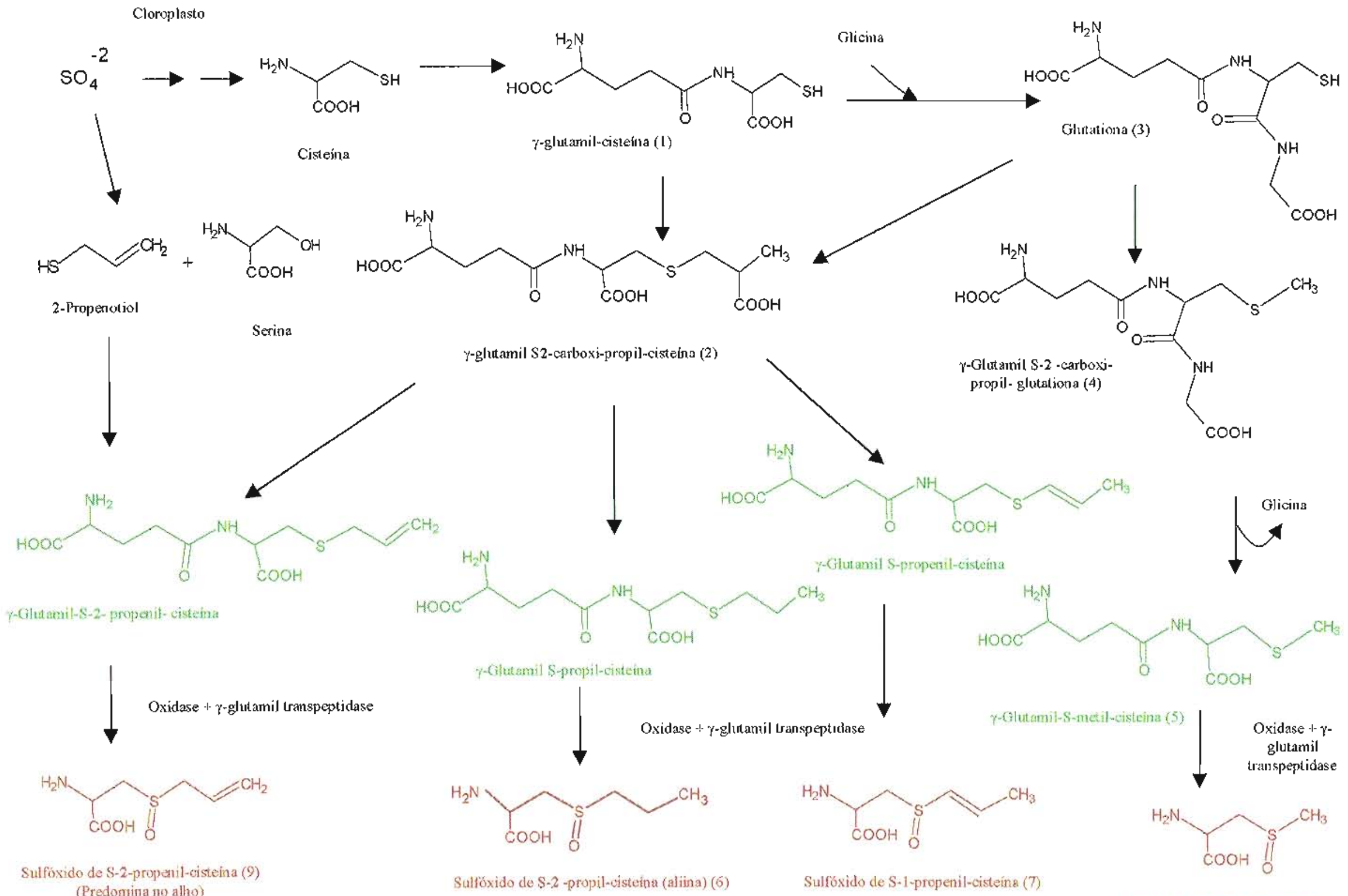

Figura 12. Biossíntese de precursores de aminoácidos e peptideos sulfurados no gêneto Allitum. (Adtaprado de Biock. 1992) 
Inicialmente ocorre uma redução do sulfato e assimilação do mesmo na forma de cisteína no interior do cloroplasto, quando então sofre a adição do ácido glutâmico pela ação da $\gamma$-glutamil-cisteína sintetase, originando a $\gamma$-glutamil-cisteina (1) (ANDERSON, 1980)

A $\gamma$-glutamil-cisteína (1) é uma substância chave, porque pode seguir duas vias metabólicas distintas. $\mathrm{Na}$ primeira via, ela é a precursora direta da $\gamma$-glutamil-S-2carboxipropilcisteina (2).

A $\gamma$-glutamil-S-2-carboxipropilcisteína (2) após descarboxilação, oxidação e clivagem do ácido glutâmico pela ação da $\gamma$-glutamiltranspeptidase ( $\gamma$-GT) (EC 2.3.2.2), dá origem ao sulfóxido de S-2-propilcisteína (6), denominado também de aliina, bem como ao sulfóxido de S-1-propenilcisteína. (7 ).O ácido glutâmico liberado é transferido para outros aminoácidos aceptores, formando novos $\gamma$-glutamil peptídeos.

Na segunda via, a $\gamma$-glutamil-cisteína (1) se transforma em glutationa pela adição da glicina (3), que por sua vez pode dar origem também à $\gamma$-glutamil-S-2-carboxipropilcisteina (2.). A metilação da glutationa (3) origina a $\gamma$-glutamil-S-2-carboxipropilglutationa (4).

Tanto a $\gamma$-glutamil-S-2-carboxipropilcisteina (2) como a $\gamma$-glutamil-S-2carboxipropilglutationa (4), são os dois $\gamma$-glutamil peptídeos que se encontram presentes em maiores quantidades na cebola (SHAW et al., 1989).

A $\gamma$-glutamil-S-2-carboxipropilglutationa (4), pela remoção da glicina origina a $\gamma$ glutamil-S-metil-L-cisteina ( $\gamma$-glutamil-SMC) (5) que, de forma semelhante ao que ocorre com a $\gamma$-glutamil-S-2-carboxipropilcisteína (2), pela ação de uma oxidase e da $\gamma$-GT, é transformada em súlfoxido de S-metil-L-cisteína (8)

Estes sulfóxidos finais, por sua vez, poderão ser degradados por outra enzima, a cisteína-S-liase (C-S-liase) (EC 4.4.1.8) gerando piruvato, amônia e os compostos sulfurados voláteis, característicos do flavor do alho e da cebola (DI PENTIMA, et al., 1995).

Ainda não está esclarecida a sintese do sulfóxido de S-2-propenilcisteina (9), que predomina no alho, sé é originário da $\gamma$-glutamil-S-2-carboxipropilcisteína (2), ou se ele provêm da serina + 2-propenotiol (BLOCK, 1992) 
Embora o processo de biossíntese dos precursores do flavor ocorra no citoplasma das células, os cloroplastos parecem ser essenciais para a sintese de grande quantidade de glutationa, necessária para dar continuidade ao processo de biossintese dos compostos aromáticos (LANCASTER \& SHAW, 1989; LANCASTER et al., 1989)

Tanto a $\gamma$-glutamil-S-1-propenilcisteína como a $\gamma$-glutamil-S-2-carboxipropil glutationa são consideradas peptídeos de reserva, pois estão ausentes em plantas de cebola antes do desenvolvimento dos bulbos, acumulando-se em concentrações que variam de 1,24 a 2,18 e de 0,4 a $0,6 \mathrm{mg} / \mathrm{g}$ do vegetal fresco. durante a formação do bulbo, respectivamente. Esta concentração mantém-se constante durante o armazenamento da cebola colhida, quando a atividade da $\gamma$-GT também é praticamente nula: Durante a germinação do bulbo, a concentração destes dois peptideos cai para menos de $50 \%$, enquanto a atividade da enzima $\gamma$-GT aumenta aproximadamente cinco vezes (SHAW et al., 1989; LANCASTER \& SHAW, 1991).

A atividade da enzima $\gamma$-GT sobre os dois $\gamma$-glutamil peptideos, acima citados, origina o aparecimento de três substâncias em grande quantidade, chamadas genericamente de sulfóxidos de S-alc(en)il-L-cisteína. São eles: o sulfóxido de S-1-propil-L-cisteína (1,9 $\mathrm{mg} / \mathrm{g}$ de vegetal fresco), o sulfóxido S-1-propenil-L-cisteína $(0,9 \mathrm{mg} / \mathrm{g}$ de vegetal fresco) e o sulfóxido de S-metil-L-cisteína $(0,9 \mathrm{mg} / \mathrm{g}$ de vegetal fresco). A concentração destas substâncias é que pré-determina o potencial de flavor do vegetal (LANCASTER \& KELLY, 1983).

As vias de biossíntese e metabolização apresentadas anteriormente, possivelmente são comuns a outras familias de vegetais, embora a concentração relativa de cada uma destas substâncias formadas, seja regulada pela presença e pela atividade das enzimas envolvidas, bem como pela presença dos respectivos substratos. Infelizmente não existem estudos sistemáticos sobre a distribuição de $\gamma$-glutamil peptideos sulfurados e de aminoácidos sulfurados livres nas diversas famílias de vegetais

Os vegetais da família Cruciferae são naturalmente ricos em sulfóxido de $\mathrm{SMC}$, que ocorte na forma de aminoácido não protéico (MAW, 1982; DERBALI et al, 1998). O flavor característico desses vegetais, considerado desagradável, é produzido pela ação da enzima C-S-liase sobre estes sulfóxidos, formando primeiramente o metanotiol. Mas as substâncias $\gamma$-glutamil peptideos e os aminoácidos não oxid́ados, parecem não constituir os 
substratos para a enzima C-S-liase, sendo necessário e indispensável a ação prévia de uma oxidase, para que então possam sofrer a ação desta enzima. Esta afirmação foi baseada em estudos com sistemas modelo: frascos contendo $\mathrm{SMC}$, aos quais foi adicionado a couve picada, não apresentavam um aumento da sintese de metanotiol, em relação a um controle (CHIN \& LINDSAY, 1994), derrubando as hipóteses anteriores, que afirmavam, ser a SMC não oxidada, também um substrato para a enzima C-S-liase (NOMURA et al., 1963; HALL \& SMITH, 1983, HAMAMOTO \& MAZELIS, 1986).

A identificação da presença de dimetil-dissulfeto e dimetil-trissulfeto (MARKS et al., 1992), levou os pesquisadores CHNN \& LINDSAY (1994) a estabelecer o mecanismo de biossintese para a sua formação, sugerindo que a selecão de cultivares de couve, ou de Brássicas em geral, pobres em sulfóxido de $\mathrm{SMC}_{2}$ ou com reduzida atividade da enzima CS-liase, poderia ser útil para a obtenção de couves com menor "off-flavor" (CHINN \& LINDSAY, 1994)

No gênero Allium, ao qual pertence o alho (Allium cepa L.), o flavor pungente é proveniente da ação conjunta das enzimas $\gamma$-glutamil peptidase e da $\mathrm{C}$-S-liase sobre os precursores inodoros e não voláteis (sulfóxidos de $\mathrm{S}$-al(en)il-L-cisteína). No alho, grande parte destes aminoácidos S-substituídos estão ligados ao ácido glutâmico, formando os $\gamma$ glutamil peptídeos que, só serão susceptiveis à ação da C-S-liase, quando forem hidrolisados (MÜTSCH-ECKNER et al., 1992; HANUM, 1995). Aparentemente, estas duas enzimas agem numa reação sequencial, conforme mostrado no esquema seguinte:

Y-głutamil-S-alc(en)il-L-cisteina sulfóxido + aminoácido

- $\gamma$-glutamiltranspeptidase $(\gamma-G T)$

Y-glutamil-aminoácido + sulfóxido de S-alc(en)il-L-cisteína

$$
\begin{gathered}
\text { C-S-liase } \\
-\mathrm{H}_{2} \mathrm{O}
\end{gathered}
$$


As reações enzimáticas envolvendo a ação de transpeptidação da $\gamma$-GT seguida da ação da C-S-liase, parecem ser as predominantes nos vegetais da família Alliaceae

$\mathrm{Na}$ familia Leguminosae, não foi demonstrada a presença da C-S-liase, o que explica a ausência dos compostos aromáticos

Além da ação de transpeptidação da $\gamma$-GT sobre os substratos $\gamma$-glutamil-L-cisteina elou glutationa, atribui-se-lhe também uma ação hidrolítica (MEISTER, 1994). Esta enzima possui três tipos de reaçōes sobre o metabolismo da glutationa:

1 hidrolisando o tripeptideo em $\gamma$-glutamil-ácido glutâmico + cisteína;

2 hidrolisando o tripeptídeo em ácido glutâmico + cisteinil-glicina,

$3^{\wedge}$ transferindo o ácido glutâmico para inúmeros aminoácidos aceptores protéicos ou năo protéicos, formando novos $\gamma$-glutamil peptídeos.

A grande atividade da enzima y-GT, atuando na transferência do ácido glutâmico da glutationa, é revelada pela presença de consideráveis quantidades de $\gamma$-glutamilmetionina, $\gamma$-glutamil-S-metilcisteina e outros $\gamma$-glutamilpeptideos durante a maturação e a fase de armazenamento de sementes de leguminosas (KASAI et al., 1982). Confirmando esta hipótese, foi demonstrado que os aminoácidos de maior afinidade pelo grupamento $\gamma$ glutamil são em ordem decrescente: metionina, S-metilcisteína, fenilalanina, sulfóxido de S-metilcisteina, leucina e tirosina, explicando o aparecimento dos peptideos acima mencionados (THOMPSON et al., 1964; KASAl et al., 1982).

Transformações subsequentes destes precursores inodoros do flavor são atribuidas à enzima C-S-liase, quando ocorre formação de metanotiol, dimetil dissulfeto e dimetil trissulfeto e uma infinidade de outras substâncias encontradas em pequenas quantidades (HANUM et al., 1995). Algumas destas substâncias são biologicamente ativas, apresentando atividade antimicrobiana, lacrimejante, flavorizante, causando geralmente repulsa aos predadores.

A ocorrência de $\gamma$-glutamil peptideos e dos seus metabólitos sulfurados em todas estas familias de plantas, embora dependam das enzimas responsáveis pela sua degradação, parece estar a nivel genético. 


\section{Isolamento e identificação de peptideos $\gamma$-glutamil sulfurados}

Os $\gamma$-glutamil-peptideos e seus aminoácidos livres, são encontrados na fração nãoproteica de extratos vegetais; reagem com a ninhidrina e, no caso de envolverem aminoácidos sulfurados, reagem também com a substância iodoplatinato. Entretanto, aminoácidos sulfurados na forma oxidada (sulfóxido ou sulfona de metionina, ácido cistéico). ou na forma de dissulfeto (cistina) e grupos sulfidrílicos livres não reagem com o iodoplatinato, reagente que é especifico para o grupamento terminal metiltio (S-CH3).

Os $\gamma$-głutamil-peptídeos são solúveis em água, sendo comumente extraidos do vegetal com água, metanol-água ou etanol-água. Soluções etanólicas são preferidas, devido à concomitante inativação de enzimas e a uma insolubilização parcial de proteinas contaminantes (ZACHARIUS, 1970, EVANS \& BOULTER, 1975, KASAI et al., 1986). A seguir o isolamento dos peptídeos é realizado através da completa adsorção, tanto de aminoácidos livres, como de peptídeos, em resinas de troca catiônica e eluição com piridina ou solução de amônia. Os $\gamma$-glutamil-peptídeos com características ácidas, podem ser isolados das demais substâncias, pela passagem por resinas de troca aniônica, normalmente na forma de acełato, utilizando ácido acético como eluente. A ordern de eluição depende da concentração do ácido e das propriedades de ionização em função do $\mathrm{pH}$ e da força iônica de cada peptideo, ou aminoácido em particular (KASAI \& LARSEN, 1980).

Todo este procedimento deverá ser realizado à temperatura de 4 a $6^{\circ} \mathrm{C}$ e num prazo de tempo nāo superior a 6 horas (THOMPSON et al., 1959). A identificação dos aminoácidos constituintes, era realizada no passado recente, por cromatografia em camada delgada (TlC) ou em papel, comparando-se os tempos de retenção com padrões de aminoácidos e por reações especificas para certos grupos funcionais. Os peptídeos eram identificados, pela mesma cromatografia em camada delgada antes e após a sua hidrólise, comparando-se os tempos de retenção e identificando-se então, os aminoácidos constituintes (LANCASTER \& KELLY, 1983).

Estas metodologias empregadas para a identificação, foram sendo substituidas por métodos mais modernos, especialmente pela espectrometria de massa e ressonância magnética nuclear. No entanto, os procedimentos através da TLC, continuam tendo o seu valor e utilidade, para testes iniciais de triagem (DI PENTIMA et al., 1995; LI et a! , 1996) 
A quantificação dessas substâncias, uma vez isoladas e identificadas, é realizada por análise em autoanalisador de aminácidos, GC-MS, ou por HPLC, comparando-se as áreas nos cromatogramas, com as áreas de aminoácidos sintéticos.

A $\gamma$-glutamil-SMC em particular, pode ser quantificada pela reação com brometo de cianogênio, analisando-se o metiltiocionato formado, através da cromatografia em fase gasosa (DUNCAN et al., 1984). Este método é utilizado com o objetivo de estimar o teor de metionina, considerada nutricionalmente disponivel, porque ela reage exclusivamente com a metionina na forma reduzida, não reagindo com o sulfóxido de metionina ou mesmo com a sulfona de metionina. O grupo $\mathrm{S}-\mathrm{CH}_{3}$, que dá origem ao metiltiocianato, está presente na metionina, na $\gamma$-glutamil-SMC e na SMC livre, interferindo na análise da metionina, levando a uma superestimação da quantidade deste aminoácido, se houver presença da $\gamma$-glutamil-SMC. A SMC livie não reage com o brometo de cianogênio (ELLINGER \& DUNCAN, 1976, MCINTOSH \& ELLINGER, 1976; DUNCAN et al, 1984; KOHNHORST et al, 1987).

Esta interferência foi avaliada por nós (LANFER MARQUEZ et al., 1996), analisando-se cinco variedades do feijão Carioca (Phaseolus vulgaris L.).

Identificamos e quantificamos em nosso laboratório, o teor de $\gamma$-glutamil-SMC e de SMC livre. Após a obtenção da fração nitrogenada não protéica, realizada pela extração com solução etanólica a $20 \%$ e purificação com resinas de troca catiônica e aniônica, quantificamos estas substâncias através da análise dos aminoácidos após hidrólise ácida, utilizando como padrão a SMC sintética.

O teor de $\gamma$-glutamil-SMC encontrado foi muito alto, variando entre 7,0 e 10,4 $\mu$ moles/g de semente de feijão nas 5 variedades. A concentração média de metionina nos feijões é da ordem de $1,4 \mathrm{~g} / 100 \mathrm{~g}$ de proteina, o que corresponde a 20,6 $\mu$ moles/g de feijão, se o teor protéico for de 22\% (RAYAS-DUARTE et al., 1988; KÖHLER \& BURKE, 1988 ; PEACE et al., 1988; MARLETTA et al., 1992).

Assim, de acordo com os nossos resultados, foi possivel calcular a interferência da $\gamma$-glutamil-SMC na análise do teor de metionina. o teor de metionina pode estar superestimado em até $50 \%$ se este aminoácido for determinado pelo método da reação com brometo de cianogênio. 
Sugerimos neste trabalho que a análise da metionina através da quantificação do metiltiocianato, não deve ser empregada em leguminosas que contenham $\gamma$-glutamil-SMC. (LANFER MARQUEZ et al., 1996). 


\section{PARTE II}

\section{Concentração e importância de aminoácidos e peptídeos $\gamma$-glutamil sulfurados em sementes de leguminosas.}

\section{Introdução}

A ampla distribuição de compostos $\gamma$-glutamil peptideos e de S-metil-L-cisteína em vegetais, suscitou estudos voltados para as sementes de leguminosas, pois a família Leguminosae compreende grande parte dos feijões que fazem parte do hábito alimentar da população de muitos países, especialmente do Brasil. O feijão comum (Phaseolus nulgaris L.) está entre os mais importantes, sendo cultivado nos cinco continentes, sendo o Brasil o maior produtor mundial desta leguminosa. Segundo dados do IBGE, a produção de fejjão em nosso pais, foi de aproximadamente 2,11 e de 3,10 × $10^{6}$ toneladas em 1997 e em 1999, respectivamente, cabendo às regiôes Sul e Nordeste, a maior produção (SIDRA Sistema IBGE de Recuperação Automática, 2000).

A descoberta, nas décadas de 1950 a 1960, de inúmeros $\gamma$-glutamil peptídeos nas mais diversas plantas e os primeiros estudos relativos à sua significância no organismo animal, estimulou os pesquisadores a traçar o rumo dos seus estudos na direção de vegetais comestiveis, em especial, vegetais da família Leguminosae. Criar metodologias mais sensiveis e específicas para a quantificação dessas substâncias, vem sendo um grande desafio

As referências encontradas na literatura sobre os teores de $\gamma$-glutamil peptídeos nas leguminosas e as informações divulgadas por pesquisadores, correspondem a resultados obtidos no passado, de amostras isoladas e analisadas apenas uma única vez. Até há aproximadamente uma década atrás, estas substâncias recebiam pouca atenção dos cientistas, exceto por aqueles, preocupados com a identificação de novos constituintes nos vegetais.

Desde então, a lista de peptídeos identificados pelas pesquisas vem crescendo continuamente. $\mathrm{Na}$ década de 70 , com o advento de métodos cromatográficos mais sofisticados, os pesquisadores preocuparam-se também com a sua quantificação, com o intuito de encontrar uma explicação plausivel da sua existência e da sua função dentro do 
intrincado metabolismo secundário dos vegetais, bem como propor, por ocasião da ingestão destes peptídeos, uma via de metabolização dos mesmos.

As primeiras informações relativas ao feijão, datam de 1949, quando PARTRIDGE \& WESTALL evidenciaram a existência de substâncias sulfuradas na fração nitrogenada não protéica destas sementes, através da reação com iodoplatinato. THOMPSON et al. em 1956, confirmaram a existência de S-metil-L-cisteina (SMC) em feijões, extraindo este aminoácido com etanol a $50 \%$ e precipitando-o com acetato de mercúrio, sugerindo a possibilidade da SMC estar presente sob a forma de um dipeptídeo, a $\gamma$-glutamil-S-metilL-cisteina ( $\gamma$-glutamil-SMC). ZACHARIUS et al., em 1958, foram os primeiros responsáveis pelo isolamento e purificação do peptídeo $\gamma$-glutamil SMC, embora as evidências para a sua identificação ainda fossem incompletas. A ligação gama foi confirmada através da reação do peptídeo com ninhidrina, fornecendo $95 \%$ do $\mathrm{CO}_{2}$ teoricamente disponivel; este valor é semelhante ao obtido com um aminoácido livre ( $96 \%$ para a leucina).

Em 1959, ZACHARIUS et al., modificaram o metodo de extração e purificação descrito anteriormente, obtendo um rendimento maior. A identidade do composto foi confirmada por comparaçăo com o dipeptideo obtido por síntese, a partir da metilação da glutationa e hidrólise com a enzima carboxipeptidase. A $\gamma$-glutamil-SMC isolada nestas condições, correspondia a $1 / 3$ do nitrogênio não protéico nos feijões maduros das varidedades "kidney" e "snap". Nessa época, os autores sugeriram que este peptídeo poderia ser uma substância de reserva, fornecendo grupos metila e originando a $\gamma$ glutamilcisteína, que é um precursor direto da glutationa

Paralelamente outros autores, identificaram e quantificaram a $\gamma$-glutamil-SMC, também em "lima beans" (Phaseohis lumatus L), encontrando teores similares aos do feijão Phaseolus vulgaris, L. (RNNDERKNECHT et al., 1958). A identificação de $\gamma$ glutamil-leucina, $y$-glutamil-fenilalanina, em sementes de soja, por MORRIS \& THOMPSON, em 1962, estimulou a realização de experimentos voltados para a possível identificação de mais substâncias, até então desconhecidas.

Todavia ainda hoje, são escassas as informações que temos na literatura a respeito do teor de $\gamma$-glutamil peptídeos sulfurados em leguminosas comestiveis. ZACHARIUS 
(1970) encontrou, em sementes secas de "bush bean" (Phaseolus vulgaris L.), variedade Tendergreen), um teor de 11,5 umoles/g de semente de $\gamma$-glutamil-SMC, medido como SMC total após hidrolisar o peptideo por 22 horas com $\mathrm{HCl} 6 \mathrm{~N}$, procedimento que vem sendo adotado rotineiramente até hoje para efetuar a hidrólise de proteinas

Em 1972, KASAI e colaboradores, identificaram a presença de diversos $\gamma$-glutamil peptídeos em sementes de Vigna radiata, além daqueles peptídeos que já tinham sido evidenciados em sementes de feijão comum. Determinaram assim, na Vigna radiata, a presença de $\gamma$-glutamil-L-tirosina e de um tnipeptídeo, a $\gamma$-głutamil- $\gamma$-glutamil-L-metionina (KASAl et al., 1972a, 1972b)

O peptídeo $\gamma$-glutamil-L-fenilalanina foi detectado também nessa época, embora em quantidades variáveis, nas sementes de leguminosas de três espécies de Dolichos e em sementes de soja. As concentrações de $\gamma$-glutamil-L-fenilalanina variaram numa ampla gama de valores, situando-se entre 0,47 e $3,35 \mathrm{mg} / \mathrm{g}$ de semente (MORRIS \& THOMPSON, 1958; DARDENNE \& THONART, 1973).

Em 1974, KRISTENSEN e colaboradores, citaram também a identificação de diversos $\gamma$-glutamil peptídeos em sementes de Fagus silvatica L., sendo que a $\gamma$-glutamilL-fenilalanina e a wilardina [3-(1-uracil)-alanina], encontravam-se presentes em maior concentração

A presença de certos $\gamma$-glutamil peptideos nos vegetais, poderia ser usada como uma característica taxonômica, possibilitando assim uma distinção entre as espécies. As espécies do gênero Vigna (Vigna radiata e Vigna mungo), por exemplo, são dificilmente diferenciadas entre si, com base apenas nas suas caracteristicas botânicas. Todos os cultivares da espécie Vigna radiala se caracterizam pela presença de elevada concentração de $\gamma$-glutamil-SMC, enquanto a espécie Vigna mungo é rica em $\gamma$-glutamil-L-metionina (OTOUL et al., 1975)

KASAI et al., em 1986, utilizando esta característica bioquimica como parâmetro de classificação, identificou sementes provindas da China, como pertencentes à espécie Vigna radiata.

$\mathrm{Na}$ tentativa de estabelecer uma divisão sistemática e uma classificação desses compostos em grupos químicos, KASAJ \& LARSEN (1980) propuseram uma divisão dos 
$\gamma$-glutamil peptideos em seis categorias, de acordo com a sua presença, em classes botânicas bem definidas.

I - $\gamma$-glutamil peptídeos de aminoácidos protéicos

II - $\gamma$-glutamil peptideos de aminoácidos nāo-protéicos, não contendo enxofre ou selênio.

III - $\gamma$-glutamil tripeptideos, não contendo enxofre ou selènio.

IV - $\gamma$-glutamil tripeptídeos, não protéicos, contendo enxofre ou selênio

$V$ - $\gamma$-glutamil tripeptideos, excetuando a glutationa, contendo enxofre ou selênio.

VI - y-glutamil derivados de aminas.

Entretanto, compostos dos diferentes grupos tem sido encontrados simultaneamente no mesmo vegetal, dificultando o estabelecimento de um padrão de distribuição

Anteriormente a esta classificação, os mesmos autores haviam proposto uma classificação mais geral de leguminosas, classificando as sementes em três grandes grupos, de acordo com a presença de $\gamma$-glutamil peptideos (KASAI et al., 1975).

Grupo I: sementes com elevado conteúdo de $\gamma$-glutamil-fenilalanina e $\gamma$-glutamiltirosina.

Grupo II: sementes com reduzidas concentrações de $\gamma$-glutamil-fenilalanina e $\gamma$ glutamil-tirosina, mas elevadas concentracões de outros $\gamma$-glutamil-peptideos.

Grupo III: sementes contendo baixa concentração ou nula de $\gamma$-glutamil peptídeos

A soja (Glycine max), pertence ao Grupo [, a Vicia faba ao Grupo III, mas a grande maioria das leguminosas comestiveis pertence ao Grupo II.

São exemplos deste Grupo II: Phaseolus radiams; Phaseolus angularis e Phaseolus vulgaris; os seus peptideos predominantes são aqueles que possuem enxofre na molécula. Há algumas décadas, os pesquisadores identificavam a ocorrência do aminoácido sulfurado, que dava origem ao $\gamma$-glutamil peptídeo, como se a sua presença fosse um artefato do processo de extração e purificação, causado pela hidrólíse do dipeptídeo. No entanto, sabemos agora, que tanto o aminoácido quanto o peptídeo podem estar presentes ao mesmo tempo na semente, embora uma das características das 
leguminosas seja a predominância de peptideos, especialmente os sulfurados, como a $\gamma$ glutamil-SMC, em detrimento dos aminoácidos livres. Dados quantítativos são escassos na literatura, mas tudo indica que o feijão comum (Phaseohus vulgaris L.) possui a maior quantidade desses peptídeos sulfurados não oxidados dentre as leguminosas comestiveis. A ordem de grandeza desses peptideos é de $11.5 \mu$ moles/g de semente, enquanto que o teor de sulfóxido de $\gamma$-glutamil-SMC (peptídeo oxidado), tão abundante em alho e cebola, corresponde no feijão a apenas $1 / 10$ da concentração de $\gamma$-glutamil-SMC. Foram encontradas ainda pequenas quantidades de outros $\gamma$-glutamil peptideos, tais como $\gamma$ glutamil-L-metionina, $\gamma$-glutamil-L-fenilalanina e $\gamma$-glutamil-L-leucina (ZACHARIUS, 1970).

EVANS \& BOULTER, em 1975, estudaram comparativamente as sementes comestiveis da maioria das leguminosas, relacionando-as quanto ao seu teor de $\gamma$-glutamilSMC e de SMC livre. Estas duas substâncias foram encontradas em quantidades significativas e em ordem decrescente nas seguintes espécies: Phaseolus vulgaris, Vigna aureus, mais recentemente denominada Vigna radiata, ou "green gram", Vigna unguiculata (feijão Caupi ou feijão de corda), Phaseolus lunatus ("lima bean"), Pisum sativum (ervilha), Cajamus cajan (feijão Guandu), Vicia faba major e minor, Glycine max (soja), Lupimis albus (tremoço) e em Sphenostylis stenocarpa (um feijão originário da África). As demais espécies analisadas, continham quantidades insignificantes destas substâncias. O estudo comparativo das sementes comestiveis anteriormente citadas, levou os autores a concluirem que o Phaseolus vulgaris continha a maior concentração de SMC $(0,87 \mathrm{~g} \mathrm{SMC} / 100 \mathrm{~g}$ proteina), determinada após hidrólise ácida do peptideo e expresso em equivalentes de SMC. Esta concentração, equivale a 14,1 $\mu$ moles de SMC/g semente do feijão, considerando um teor protéico de $22 \%$ na semente. A concentração de SMC encontrada nas outras sementes, foi em ordem decrescente: feijão Caupi (Vigna unguiculata) $(0,56 \mathrm{~g} \mathrm{SMC/100} \mathrm{g} \mathrm{proteína),} \mathrm{feijão} \mathrm{mungo} \mathrm{ou} \mathrm{"mung} \mathrm{bean"} \mathrm{(Vigna} \mathrm{aureus),}$ muito consumido nos paises asiáticos $(0,50 \mathrm{~g} S \mathrm{SMC} / 100 \mathrm{~g}$ proteína) e feijão lima (Phaseohus hunatus), contendo $0,43 \mathrm{~g}$ SMC/100 g proteina) de equivalentes de SMC na proteina. 
Nos últimos 25 anos, nenhum outro trabalho sistemático sobre a distribuição destes peptídeos sulfurados em sementes de leguminosas foi encontrado na literatura. As nossas recentes pesquisas relacionadas com os efeitos fisiológicos destas substâncias, motivaramnos para um estudo voltado para a identificacão e quantificação dos $\gamma$-glutamil peptídeos sulfurados majoritários, encontrados em leguminosas comestiveis. Levamos em consideração o consumo de leguminosas pela população brasileira, ou então, a possibilidade do seu cultivo ser introduzido em nosso país (LANFER MARQUEZ et al., 1996; BARROS \& LANFER MARQUEZ, 1996; REIS GIADA, et al., 1998; BARROS et at., 1998).

Em relação às espécies de leguminosas consumidas, existem diferenças de acordo com o hábito alimentar e a adaptação da cultura vegetal às condições climáticas e solo $\mathrm{Na}$ América Latina, em especial no Brasil, a leguminosa mais consumida é o Phaseolus vulgaris (SGARBIERI, 1980).

Na região Norte e Nordeste do Brasil, o feijão de Corda ou Caupi, pertencente à espécie Vigna unguiculata, desempenha importante papel na alimentação devido às suas características nutricionais, assemelhando-se muito ao feijão Phaseolus vulgaris. Tanto em nosso país, como em outros também, a produção do feijão Vigna unguiculata é incluida na estatística do feijão Phaseolus vulgaris, nas suas diversas variedades. Portanto, dados de produção desta leguminosa isolada não estāo disponiveis na literatura.

O feijão Adzuki, ou "rice bean" (Vigna umbellata) é uma leguminosa de origem do sul e sudeste da Ásia, sendo útil como planta forrageira e como fonte protéica para a alimentação humana em alguns paises como Índia, China e Filipinas, possuindo ao redor de $18 \%$ de proteína na semente (RODRIGUEZ \& MENDONZA, 1991). Este feijoeiro caracteriza-se por sua elevada resistência às pragas e doenças, sendo capaz de desenvolver-se em solos pobres e em climas quentes e úmidos (KAUR \& KAPOOR 1990, 1992). O seu consumo no Brasil vem crescendo, especialmente entre a população de origem asiática.

O feijão Guandu, (Cajamus cajan L.) é outra leguminosa de consumo crescente, especialmente pela população da zona rural de diversos Estados brasileiros, tendo sido 
objeto de estudo e de melhoramento genético, com as perspectivas de desenvolvimento de novas variedades. (CANNIATTI-BRAZACA et al., 1993, 1996).

O feijão de porco (Canavalia ensiformis), vem sendo estudado, devido à sua importância como ração e à sua conhecida toxicidade, causada pela presença de uma lectina, denominada concanavalina-A, procurando-se encontrar meios bioquímicos que possam diminuir ou até inativar essa lectina.

O "Complexo Vigna" é composto por duas espécies de leguminosas: a Vigna radiala e a Vigna mungo, de dificil distinção sob o ponto de vista morfológico.

Estas leguminosas são cultivadas rotineiramente em várias regiões da Ásia, fazendo parte do hábito alimentar daquela população, sendo consumidas na forma cozida ou como broto de feijão (VIGNA CROP GERMPLASM COMMUTTEE, 1996). Cerca de 70\% da produção mundial desses grãos ocorre na Índia, país que destina $12 \%$ de sua área cultivável à produção dessas sementes. A maior produção anual corresponde à Vigna radiata (854 toneladas em 1978), enquanto que a Vigna mungo contribuiu, no mesmo ano, com 698 toneladas. A Tailândia, que aumentou a sua produção em seis vezes no período de 1965 a 1985, representa o segundo produtor, exportando $40 \%$ da colheita para outros paises, como Japão, Taiwan, Filipinas, Malásia, Singapura, Europa e EUA (LAWN \& $\mathrm{AHN}, 1985)$. Existe uma tendência de aumento da produção de V'igna mungo para outros países, sendo o seu potencial agronômico e tecnológico ainda subexplorado; a produção avaliada em apenas $500 \mathrm{Kg}$ /hectare poderia atingir $2700 \mathrm{Kg} /$ hectare. De acordo com LAM-SANCHEZ, 1989, eias poderiam ser cultivadas no Brasil em terras baixas e o solo poderia ser não muito rico, já que este feijoeiro se desenvolve muito bem em qualquer tipo de solo que possua um regime pluviométrico entre $600-900 \mathrm{~mm}$, constituindo-se uma alternativa ao consumo do nosso habitual feijāo da espécie Phaseolus vmlgaris, L.

Apesar de sua longa história na agricultura asiática, as sementes de Vigna mungo e Vigna radiata, têm recebido pouca atenção dos pesquisadores, tanto no aspecto de melhoramento genético, quanto ao estudo de suas caracteristicas nutricionais. Com relação à composição de aminoácidos, a Vigna mungo apresenta um teor de metionina superior à Vigna radiata, talvez devido à presença do peptideo $\gamma$-glutamil-L-metionina, na 
Vigna mungo. Este fato pode ser relevante, considerando que os aminoácidos sulfurados são limitantes em sementes de leguminosas.

Estudamos os teores do peptídeo $\gamma$-glutamil-SMC e de SMC livte em 45 sementes dos gêneros Phaseolus, Vigna, Cajamus e Cancrvalia. A fração nitrogenada não protéica foi extraída com solução etanólica, a $\gamma$-glutamil-SMC parcialmente purificada $e$ após hidrólise ácida, quantificada na forma de SMC em autoananalisador de aminoácidos. Um método alternativo para a quantificação, foi realizado por comparação das áreas do aminograma de um extrato do feijão não hidrolisado, com a área de um padrão de $y$ glutamil-SMC, sintetizado em laboratório (BARROS et al, 1999).

Os teores de $\gamma$-glutamil-SMC e de SMC livre encontrados estão apresentados na

\section{Tabela 4 .}

Foram analisadas nesta pesquisa, nove variedades de feijão (Phaseohus vulgaris L.), compreendendo este trabalho, o primeiro a apresentar resultados de um estudo mais amplo relacionando diferentes variedades da mesma espécie de leguminosa.

Os feijōes da espécie Phaseolus vulgarıs L. apresentaram os maiores teores do dipeptideo $\gamma$-glutamil-SMC, entre todas as especies estudadas, sendo que as concentrações variaram entre 4, I e 12,6 $\mu$ moles equivalentes de $\mathrm{SMC} / \mathrm{g}$ de feijăo em base seca, com um valor médio de 8,3 pmoles. Este valor, somado ao teor de SMC livre $(0,36$ a 3,16 $\mu$ moles/g feijão), corresponde em média a 10,9 $\mu$ moles equivalentes de SMC por grama de semente de feijão seco. O teor de SMC livre representa aproximadamente $24 \%$ deste total

Estes resultados confirmam os elevados teores deste peptídeo no feijão comum, encontrados também por ZACHARIUS em 1970 e por EVANS \& BOULTER, em 1975 Este teor, de 10,9 umoles equivalentes de $\mathrm{SMC} / \mathrm{g}$ feijão convertido em gramas e considerando a concentração protéica de $22 \%$ no feijão, corresponde a aproximadamente $0,65 \mathrm{~g}$ de SMC/100 g proteína. Considerando ainda que o feijão possui, em média, 1,4\% de metionina na proteina, como já mencionamos anteriormente, a quantidade de SMC encontrada, pode representar até $50 \%$ do teor de metionina presente nestes fejjōes. Este valor encontrado é muito alto, não tendo sido suspeitado anteriormente. 
As sementes do gênero Vigha apresentaram teores de $\gamma$-glutamil-SMC variáveis em função da espécie. A espécie Vigna unguiculata à qual pertence o feijão Caupi, possui um teor de $\gamma$-glutamil-SMC variando entre 2,47 e 3,44 $\mu$ moles equivalentes de $\mathrm{SMC} / \mathrm{g}$ feijão seco, entre as nove variedades estudadas. O valor médio foi de $2,68 \mu$ moles $/ \mathrm{g}$ feijão seco. Apesar desse valor ser relativamente baixo quando comparado aos valores encontrados no feijão Phaseolus vulgaris L., foram observados valores muito elevados para a SMC livre correspondendo em média a $4,8 \mu$ moles SMC/g feijão em base seca Este valor representa $63 \%$ da SMC proveniente do peptideo. Com isto, o valor total de equivalentes de SMC atinge 7,5 $\mu$ moles SMC/g feijão em base seca (BARROS et al, 1998). Até este momento não temos uma explicação para este valor elevado de SMC na forma livre

A espécie Vigna radiata possui um teor de equivalentes de SMC de 7,49 $\mu$ moles/g feijão seco, correspondente à soma da $\gamma$-glutamil-SMC + SMC livre. Este valor é relativamente elevado e semelhante à concentração encontrada no feijão Caupi, da ordem de $6,8 \mu$ moles/g feijão em base seca, em média; nas sementes de Vigna radiata, a SMC livre participa em $42 \%$ deste total.

Já na espécie Vigna mungo, não foi encontrado o peptideo $\gamma$-glutamil-SMC em quantidades mensuráveis. Porém foi identificada a presença de outro peptídeo sulfurado, a $\gamma$-glutamil-metionina (BARROS et al, 1998). Estes resultados estão de acordo com evidências descritas na literatura, permitindo a diferenciação das espécies Vigna radıata e Vigna mungo com base no seu conteúdo peptídico (OTOUL et al., 1975). Essas evidências permitiram sugerir que a espécie Vigna radiata, ter-se-ia originado do gênero Phaseohis, enquanto a espécie mungo, seria proveniente do gênero Vigna, apontando para a diversidade genética da origem dessas duas leguminosas

Estudos relativos à influência de fatores ambientais, tais como, condições climáticas, localização geográfica de plantio e adubação do solo, poderiam esclarecer se a concentração da $\gamma$-glutamil-SMC, nessas sementes, è uma característica genética ou se influências externas são capazes de modular o teor dos dipeptídeos nas sementes, indicando uma caracteristica fenotipica. 
A literatura encontrada não faz menção à possíveis variações na concentração desses peptídeos. Por outro lado, e de uma maneira geral, assume-se que a concentraçâo protéica em sementes de leguminosas está sujeita a variações, em função da composição do solo, da adubação e outros fatores extemos. A adição de enxofre ao solo atua diretamente no aumento do teor protéico de sementes de leguminosas, enquanto situaçōes de estresse, costumam aumentar o "pool" de aminoácidos livres. 
Tabela 4. Teores de $y$-glutamil-S-metil-L-cisteina ( $\gamma$-glutamil-SMC) e de S-metil-Lcisteina (SMC) em leguminosas comestíveis.

\begin{tabular}{|c|c|c|c|c|}
\hline \multirow[t]{2}{*}{ Leguminosas } & $\begin{array}{l}\text { Equivalentes de } \\
\text { SMC total }\end{array}$ & $\begin{array}{l}\text { Y-glutamil- } \\
\text { SMC }\end{array}$ & SNG:livre(*) & $\%$ SMC livre \\
\hline & \multicolumn{4}{|c|}{$\mu$ moles/g semente (base seca) } \\
\hline \multicolumn{5}{|l|}{ Phaseolus vilgaris $I_{\sim}(n=9)$} \\
\hline Safira & 9.72 & $7,75 \pm 0,39^{(\circ)}$ & $1,97 \pm 0,09$ & 20.27 \\
\hline Pintado & 8,97 & $4,05 \pm 0,20^{\circ}$ & $4,92 \pm 0.17$ & 54.85 \\
\hline Carioca & 12,54 & $9,88 \pm 0,85^{\circ}$ & $2,66 \pm 0,06$ & 21,21 \\
\hline Iapar 14 & 12,91 & $9,75 \pm 0,35^{\circ}$ & $3,16 \pm 0,01$ & 24,48 \\
\hline lapar 57 & 13.89 & $11.22 \pm 0.94^{(\circ)}$ & $2.67 \pm 0,64$ & 19,22 \\
\hline lapar-31 & 6,98 & $6,62 \pm 0,24^{(\cdots)}$ & $0,36 \pm 0,01$ & 5.16 \\
\hline Іарат-16 & 7,75 & $5,71 \pm 0,61^{(\cdots)}$ & $2,04 \pm 0,11$ & 26,32 \\
\hline Maravilha & 15,49 & $12.59 \pm 1,25^{(9)}$ & $2,90 \pm 0,05$ & 18.72 \\
\hline Iapar-8 & 9,91 & $7,26 \pm 0,13^{(*)}$ & $2,65 \pm 0,08$ & 26,74 \\
\hline Média & 1091 & 8,31 & 2,59 & 24,11 \\
\hline \multicolumn{5}{|l|}{ V. unguiculata $(n=9)$} \\
\hline Caupi & 5,39 & $2,72 \pm 0.07^{(7)}$ & $2,67 \pm 0,18$ & 49,54 \\
\hline Branco & 8,52 & $2,47 \pm 0,26^{(\cdot)}$ & $6,05 \pm 0,15$ & 71,01 \\
\hline Manleguinha & 9.92 & $3.44 \pm 0.18^{(0)}$ & $6,48 \pm 0,10$ & 65,32 \\
\hline Crome & 9.20 & $2.64 \pm 0,11^{(\cdot)}$ & $6.56 \pm 0.19$ & 71.30 \\
\hline Caldeirāo & 7,25 & $250 \pm 0,07^{(0)}$ & $4.75 \pm 0,10$ & 65,52 \\
\hline Epaci-6 & 6,62 & $2.54 \pm 0,29^{(-9)}$ & $4.08 \pm 0,16$ & 61.63 \\
\hline Qucbra-cadeıra & 7.79 & $2.66 \pm 0,02^{(*)}$ & $5.13 \pm 0,06$ & 65,85 \\
\hline Castilla & 5,96 & $2,58^{(\cdot)}$ & 3,38 & 56,71 \\
\hline Cométcio Salvador & 6,73 & $2,59 \pm 0,02(9)$ & $4,14 \pm 0,12$ & 61.52 \\
\hline Média & 7,49 & 2,68 & 4,80 & 63,16 \\
\hline \multicolumn{5}{|l|}{ Vigna radiara $(\mathrm{n}=7)$} \\
\hline Mungo $M-124$ & 9,18 & $5,63 \pm 0,33^{(-)}$ & $3.55 \pm 0,16$ & 38.67 \\
\hline Mungo (12/3/97) & 6.62 & $3,46 \pm 0,34^{(\cdots)}$ & $3.16 \pm 0,16$ & 47,73 \\
\hline Mungo M-100 & 6,35 & $3,64 \pm 0,05^{(\bullet)}$ & $2.71 \pm(1,12$ & 42,68 \\
\hline Mungo $\mathrm{M}-22$ & 6.39 & $3,71 \pm 0,20^{(-m}$ & $268 \pm 0,16$ & 41.24 \\
\hline Mungo M-80 & 6,04 & $3.83 \pm\left(1,16^{(\cdot)}\right.$ & $2,21 \pm 0,08$ & 36,59 \\
\hline Mungo $\mathrm{M}-72$ & 5,45 & $2,64 \pm 0,10^{(-9}$ & $2,81 \pm 0,10$ & 31,56 \\
\hline Mungo M-1 46 & 7,24 & $4,73 \pm 0,23^{(-)}$ & $2,51 \pm 0,11$ & 34,67 \\
\hline Média. & 6,75 & 3,95 & 2,84 & 41,98 \\
\hline lagna miango $(n=3)$ & n.d. & ก.d. & n.d & n.d. \\
\hline 1/ygna umbelana $(n=5)$ & n.d. & nd & n.d. & nd. \\
\hline Cajauns cajan $(\pi=4)$ & n.d & n.d. & nd. & nd \\
\hline Canavalio ensformi $(n=1)$ & n.d. & nd. & nd. & n.d. \\
\hline
\end{tabular}

(a) Os valores etzcontrados correspondem à módis de trís determinaçỏs, com exceçāo para of feijão Castilla (1 valor),

(*) Determinada após a hidrólise na forma de S-meti]-L-cisteina lotal, descontando-se a S-metil-L-cjsteina live,

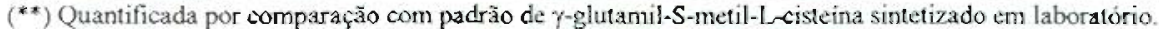




\section{Objetivos}

\subsection{Geral}

Avaliar a concentração de aminoácidos sulfurados não-protéicos em leguminosas comestiveis, bem como inferit sobre a sua via biossintética.

\subsection{Especificos}

Avaliar a influência regional e da adubação do solo com enxofre, sobre a concentração do peptídeo $\gamma$-glutamil-SMC e de SMC livre, em feijão comum (Phaseohis vulgaris L.), cultivado por dois anos consecutivos nos campos experimentais do Instituto Agronômico de Campinas (IAC) e do Instítuto Agronômico do Paraná.

Inferir sobre a via biossintética do peptideo $\gamma$-glutamil-SMC e SMC livre no feijão Phaseolus vulgaris $\mathrm{L}$.

Caracterizar quimicamente as sementes de Vigna mungo, avaliando-se a sua composição quimica, perfil de aminoácidos e presença de aminoácidos e peptideos $\gamma$ glutamil sulfurados

Avaliar a importância nutricional da presença do peptideo $\gamma$-glutamil-L-metionina presente em sementes de Vigna mungo. 


\section{Material e Métodos}

\subsection{Feijōes}

As sementes de leguminosas pertencentes às espécies Phaseolus vulgarisc L., Vigna radiata (L.) Wilczek, e Vigna mungo (L.) Hepper, foram cultivadas nos campos experimentais dos Institutos, Agronômico de Campinas - IAC e Agronômico do Paraná IAPAR. Contamos com a colaboração dos pesquisadores Roberto Tetsuo Tanaka e Eduardo Ambrosano, da Seção de Leguminosas do IAC, e dos pesquisadores Nelson da Silva Fonseca Junior e da Dra. Vânia Moda Cirino, do Laboratório de Melhoramento Genético do IAPAR, pela qual nos agradecemos

\subsection{Plantio do feijão Phaseolus vulgaris L., em diferentes localidades do Estado do Paraná}

A influência das condições climáticas, e de localização geográfica sobre a concentração da $\gamma$-glutamil-SMC, foi avaliada pela análise de dois cultivares de feijões Phaseohs vulgaris L. (feijão Carioca e Iapar-14), cujo plantio se deu em 6 regiões do Estado do Paraná: São João do Ivaí, Campo Mourão, Wenceslau Braz, Londrina, Pato Branco e Irati (KRANZ, 1989). As características das regiões de plantio das sementes e a regionalização do cultivo encontram-se na Tabela 5 e na Figura 13.

Foi utilizado um delineamento estatístico de blocos ao acaso, com quatro repetições, parcelas de 4 linhas de $5 \mathrm{~m}$, espaçadas $0,5 \mathrm{~m}$, com uma densidade de semeadura de 15 plantas por metro linear, sendo colhidas apenas as duas linhas centrais. Foram aplicados inseticidas e acaricidas, quando estes se fzzeram necessários. Adubação química de base foi feita utilizando-se N,P,K (4:30:10) utilizando aproximadamente $200 \mathrm{~kg}$ de fertilizante por hectare. Foi efetuada também a adubação em cobertura com sulfato de amônio, aplicando-se em tomo de $60 \mathrm{Kg}$ de deste sal por hectare, após 15 a 20 dias de emergência da planta, de acordo com as recomendações de PARRA (1989)

Foram analisadas as sementes colhidas na safra "das águas" de janeiro de 1997 e de 1998, de acordo com um planejamento estabelecido previamente 
Tabela 5. Localização geográfica de plantio das sementes do feijão Phaseolus vulgaris L.

\begin{tabular}{c|cccc}
\hline Regiões de plantio & \multicolumn{4}{|c}{ Coordenadas } \\
\hline & Latitude & Longitude & Altitude & $\begin{array}{c}\text { Regionalização } \\
\text { do cultivo }\end{array}$ \\
\hline São João do Ivaí & $24^{\circ} 00^{\prime} \mathrm{Sul}$ & $51^{\circ} 50^{\prime}$ Oeste & $400 \mathrm{~m}$ & VI \\
Campo Mourão & $24^{\circ} 05^{\prime} \mathrm{Sul}$ & $52^{\circ} 50^{\prime}$ Oeste & $830 \mathrm{~m}$ & VI \\
Wenceslau Braz & $23^{\circ} 50^{\prime}$ Sul & $50^{\circ} 50^{\prime}$ Oeste & $835 \mathrm{~m}$ & Il \\
Londrina & $23^{\circ} 22^{\prime} \mathrm{Sul}$ & $51^{\circ} 10^{\prime}$ Oeste & $585 \mathrm{~m}$ & II \\
Pato Branco & $26^{\circ} 07^{\prime} \mathrm{Sul}$ & $52^{\circ} 10^{\prime}$ Oeste & $700 \mathrm{~m}$ & XIII \\
lrati & $25^{\circ} 25^{\prime} \mathrm{Sul}$ & $50^{\circ} 32^{\prime}$ Oeste & $893 \mathrm{~m}$ & XIV \\
\hline
\end{tabular}




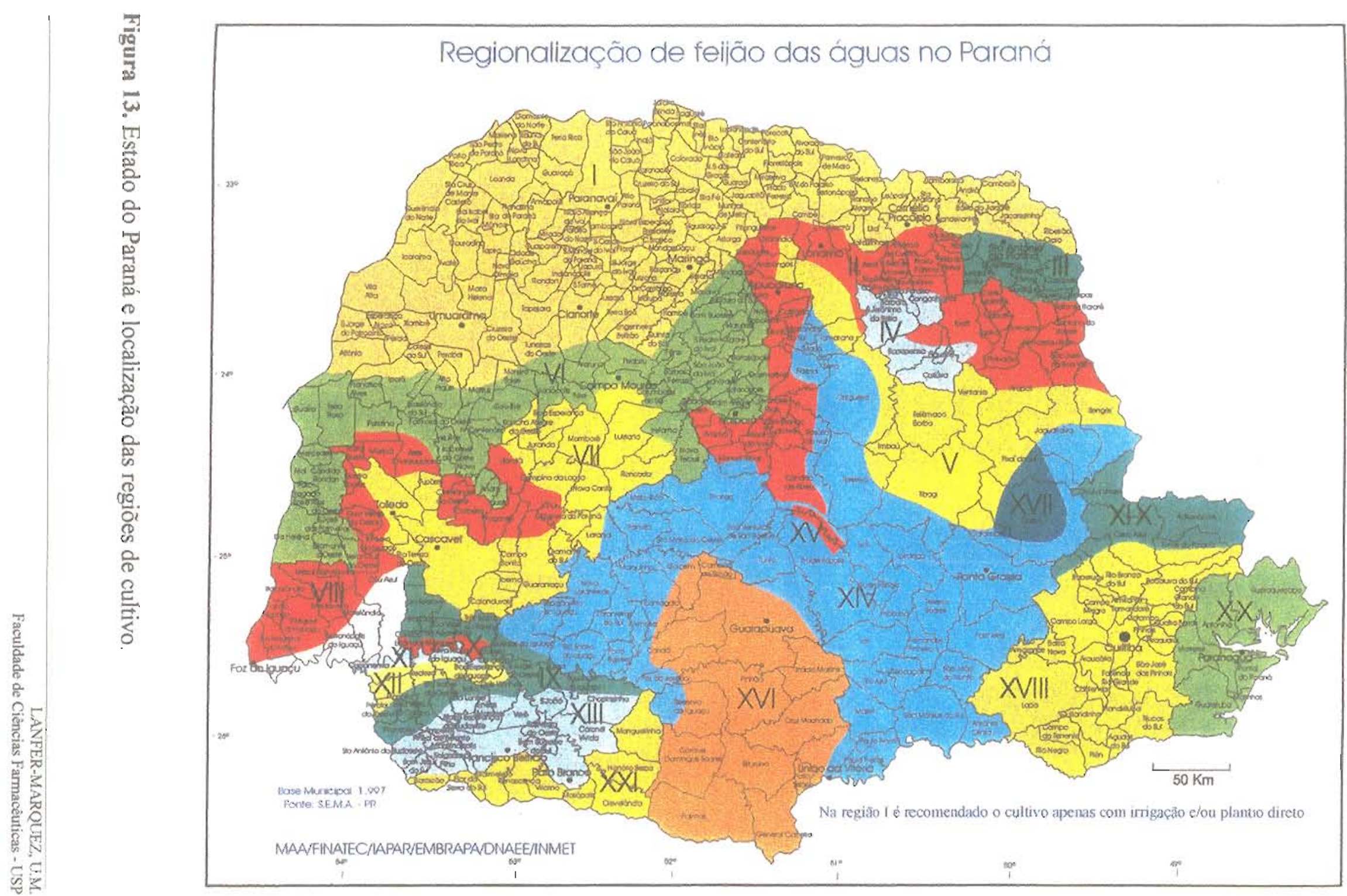




\subsection{Plantio do feijão Phaseolus vulgaris L. em solos com diferentes concentrações de enxofre}

Para verificar a influência do teor de enxofre no solo sobre a concentração da $\gamma$ glutamil-S-metil-L-cisteina, sementes de feijões Phaseolus vulgaris L., foram plantadas no Instituto Agronômico de Campinas - IAC, nas seguintes condições: o delineamento estatístico utilizado foi o de blocos ao acaso, com três repetições. As sementes foram tratadas com Tecto $(200 \mathrm{~g} / 100 \mathrm{Kg}$ de sementes) e Benlate $(100 \mathrm{~g} / 100 \mathrm{Kg}$ de semente) antes do plantio. O enxofre foi adicionado ao solo, na forma de sulfato de cálcio (gesso) nas seguintes concentrações: $0,7,14,28$ e $56 \mathrm{Kg}$ de gesso /hectare

Além dessa adubação na forma de tratamento, foram aplicados ao solo $60 \mathrm{Kg} / \mathrm{ha}$ de $\mathrm{P}_{2} \mathrm{O}_{5}$ (superfosfato triplo), $40 \mathrm{Kg} / \mathrm{ha}$ de $\mathrm{K}_{2} \mathrm{O}$ (cloreto de $\mathrm{K}$ ) e $40 \mathrm{Kg}$ /ha de oxido silicatado contendo todos os micronutrientes. Após 15 dias da emergência das plantas, foram aplicados $50 \mathrm{Kg}$ /ha de $\mathrm{N}$ (uréia) em cobertura. A dose recomendada em adubação normal é de 20 a $30 \mathrm{Kg} / \mathrm{ha}$. Foram analisadas as sementes colhidas na "safra das águas" de janeiro de 1997 e de 1998.

\subsection{Preparo das farinhas de feijões}

As sementes integras foram armazenadas em câmara fria a $5^{\circ} \mathrm{C}$ até o uso. As farinhas foram obtidas por moagem em moinho de laboratório com circulação de água (Polymix, modelo A-10, Kinematica-Luzern) e tamisadas em peneira de $0,250 \mathrm{~mm}$ de abertura.

\subsection{Composiçāo centesimal}

O conteúdo de umidade das farinhas de feijão (3g) foi determinado por método gravimétrico, em estufa a $105^{\circ} \mathrm{C}$ por aproximadamente 4 horas, até peso constante (IAL, 1985). Essa determinação, apesar de não constar dos objetivos, foi necessária para que os resultados de todos os ensaios analíticos, pudessem ser expressos em base seca e comparados entre si, independentes do teor de umidade das amostras. 
O teor de nitrogènio foi determinado pelo método de micro-Kjeldahl, utilizando-se o fator 6,25 para a conversão do teor de nitrogênio em proteína (AOAC, 1990). Os lipídeos nas farinhas foram determinados pela extração com solvente orgânico em extrator internitente Soxhlet. Cartuchos contendo aproximadamente $5 \mathrm{~g}$ de farinha, foram inseridos no aparelho e imersos em $100 \mathrm{~mL}$ de éter etílico. A extração foi completada em 6 horas, mantendo-se uma temperatura média de $36^{\circ} \mathrm{C}$ durante a extração (AOAC, 1990). O teor de resíduo fixo foi determinado por incineração da amostra (2g), em chapa elétrica, seguida de combustão em mufla a $550^{\circ} \mathrm{C}$, durante 9 horas (AOAC, 1990). A determinação do teor de fibra alimentar total e da fibra solúvel e insolúvel, foi realizada segundo método enzímático-gravimétrico descrito por PROSKY et al. (1988). Contamos com a colaboração da Dra. Tullia M.C.C. Filisetti do Departamento de Alimentos e Nutrição Experimental da FCF - USP. Todas as análises foram realizadas em triplicata.

\subsection{Composição em aminoácidos}

Os aminoácidos presentes na farinha dos feijões, foram identificados e quantificados por cromatografia de troca iônica, em autoanalisador de aminoácidos, marca Beckman, modelo 7300 (Beckman Instruments, Palo Alto, CA), após hidrólise ácida com $\mathrm{HCl} 6 \mathrm{~N}$, durante 22 horas a $110^{\circ} \mathrm{C}$ em ampolas seladas sob vácuo. Após esse tempo, o $\mathrm{HCl}$ foi removido mantendo as ampolas abertas em dessecador à vácuo, contendo pastilhas de $\mathrm{NaOH}$. Após a secagem, as amostras foram ressuspensas e diluŕdas em tampão citrato (Na-S, Beckman Instr.), para conterem uma concentração de 100nmoles de cada aminoácidos/mL e filtradas em membrana de 0,22 $\mu \mathrm{m}$. O equipamento foi operado em condições recomendad́as pelo fabricante para hidrolisados protëicos, trabalhando com coluna única de sódio, três tampões eluentes, além do reagente de regeneração da coluna e reagente de ninhidrina, todos produzidos pela Beckman. A reação dos aminoácidos com a ninhidrina ocorre pós-coluna, sendo a intensidade de cor medida em colorimetro em 570 e $44 \mathrm{~nm}$. As áreas debaixo dos picos do aminograma são integradas e comparadas às áreas dos picos de uma mistura padrão de aminoácidos, em integrador Hewlett Packard. Foi utilizado norleucina como padrão intemo. A determinação dos aminoácidos metionina e 
cisteina. foi realizada após a oxidação prévia das amostras com acidos perfórmico (MOORE, 1963)

\subsection{Extração dos aminoácidos e dos peptídeos $\gamma$-glutamil sulfurados - Obtenção do Extrato Bruto (EB)}

Para a obtenção do extrato nitrogenado não-protéico, as farinhas de feijões foram extraídas com etanol $70 \%$ duas vezes por 48 horas, intercalando-se uma centrifugação e re-extração do residuo, para permitir a completa extração de aminoácidos livres e $\gamma$ glutamil peptideos, assegurando também a inativação de enzimas. O procedimento para a extração foi o descrito por KASAI et al. (1986), tendo sido feitas algumas modificações descritas por REIS GIADA et al. (1998). No presente trabalho, a quantidade de farinha a ser extraída foi reduzida para $25 \mathrm{~g}$. A extração de cada amostra de feijão foi feita em triplicata.

A Figura 14 ilustra a os passos da extração das farinhas das diversas leguminosas, para a obtenção do Extrato Bruto (EB).

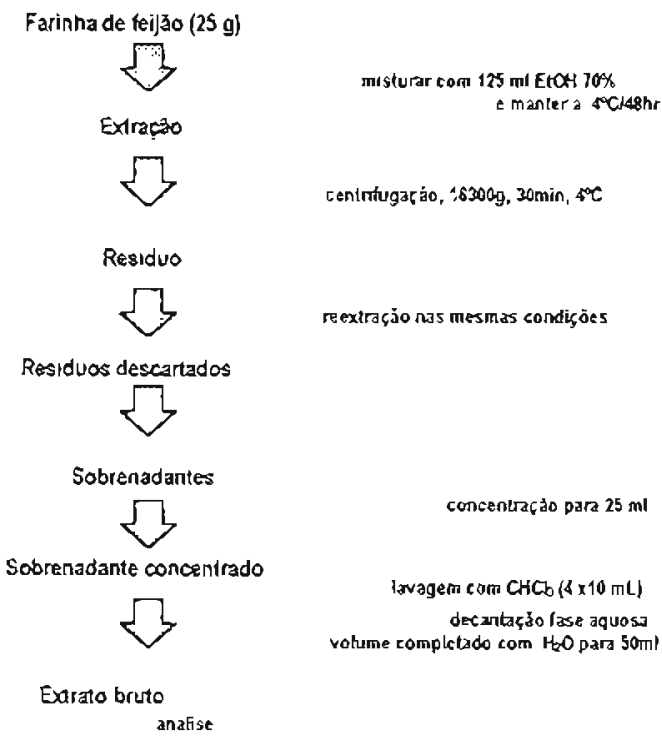

Figura 14. Fluxograma de extraçđo de peptídeos y-glutamil e oblenção do Extrato Bruto (EB) 


\subsection{Purificaçāo parcial do Extrato Bruto}

A purificação teve por objetivo a remoção de compostos neutros, especialmente carboidratos, que foram co-extraídos com o etanol 70\%. A porcentagem de carboidratos, presentes no EB, determinada em testes prévios, corresponde a aproximadamente $30 \%$ em peso, do EB. seco.

Uma coluna de vidro de $27,5 \mathrm{~cm}$ de altura e $3,8 \mathrm{~cm}$ de diàmetro, foi empacotada com resina de troca iônica Amberlite IR-120 ( $\left.\mathrm{H}^{+}, 1,9 \mathrm{meq} / \mathrm{mL}\right)$ e ativada pela passagem de $500 \mathrm{~mL}$ de $\mathrm{HCl} \mathrm{lN}$, seguida de lavagem com água até atingir pH neutro (LARSEN, 1980).

Foram aplicados $4 \mathrm{~g}$ do EB liofilizado, de cada vez, dissolvidos em aproximadamente $5 \mathrm{~mL}$ de água. As substâncias neutras foram removidas, lavando-se a coluna com $500 \mathrm{~mL}$ de água, num fluxo de $100 \mathrm{~mL} / \mathrm{hora}$ até reação negativa para carboidratos pela reação de fenol- $\mathrm{H}_{2} \mathrm{SO}_{4}$ (DUBOIS et al., 1951). Os aminoácidos, totalmente adsorvidos na coluna, foram eluidos com $\mathrm{NH}_{4} \mathrm{OH} 1,0 \mathrm{M}$ e recolbidas diversas frações, até reação negativa para compostos sulfurados reduzidos (metionina e SMC), borrifando-se iodoplatinato de potássio num papel de filtro sobre o qual se gotejou $0,2 \mathrm{~mL}$ do eluato. Manchas brancas sobre um fundo róseo indicam a presença de tais compostos (TOENNTES \& KOLB, 1951). Foram coletadas as frações de $n^{\circ} 18$ até 38 , cada uma contendo $50 \mathrm{~mL}$. Estas frações foram neutralizadas com ácido acético, liofilizadas e armazenadas em congelador até o momento de uso

A coluna de troca iônica foi regenerada pela passagem de $500 \mathrm{~mL}$ de $\mathrm{NaOH} 0,1 \mathrm{M}$ para a remoção de todos os ions, seguida de lavagem com água destilada até pH neutro $A$ ativação da coluna ocorreu de acordo com a descrição feita anteriormente.

O esquema de purificaçăo parcial do peptídeo encontra-se na Figura 15 


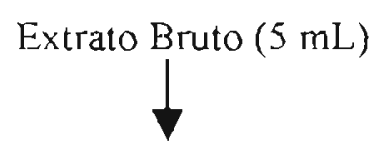

Purificação

(resina de troca catiônica, Amberlite IR-120)

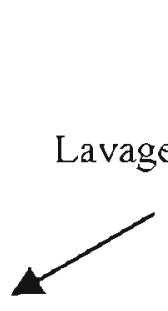

Remoção dos açúcares solúveis

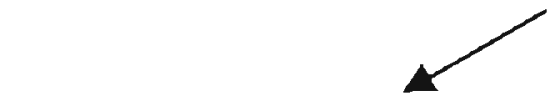

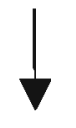

avagem com água
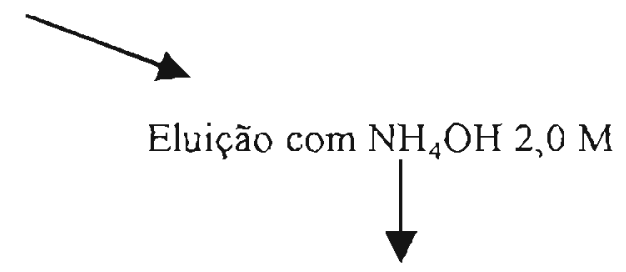

Obtenção da fração nitrogenada não protéica

Figura 15. Esquema de purificação do Extrato Bruto.

\subsection{Identificação da S-metil-L-cisteína e da $\gamma$-glutamil-S-metil-L-cisteína}

A SMC livre e a $\gamma$-glutamil-SMC, foram identificados por análise de aminoácidos, após as passagens por resinas de troca catiônica e aniônica, conforme descrição em trabalho realizado em nosso laboratório, estabelecendo-se o tempo de retenção dessas substâncias na análise de aminoácidos em condiçôes padronizadas (REIS GIADA et al., 1998).

A identificação do peptideo foi realizado de duas formas:

1) após hidrólise ácida do peptídeo purificado, comparando-se os aminogramas antes e após a hidrólise, evidénciou-se o desaparecimento do pico da $\gamma$-glutamil-SMC e o aparecimento do pico da SMC livre. A SMC foi identificada por comparação do tempo de retenção com padrão de SMC.

2) A identificação definitiva foi realizada por espectrometria de massa de dessorpção de plasma (plasma desorption mass spectrometry - PDMS) em colaboração com o Instituto de Fisica da USP (REIS GIADA et al., 1998) 


\subsection{Quantificação da S-metil-L-cisteína e da y-glutamil-S-metil-L-cisteína}

A quantificação do peptideo foi feita por duas metodologias distintas:

1) Análise indireta, após hidrólise ácida do peptídeo e medida da quantidade total de SMC em autoanalisador de aminoácidos. As leituras de absorbância foram realizadas em 570 $\mathrm{nm}$, para evitar a interferência da prolina que elui juntamente com a SMC. Os resultados foram expressos em $\mu$ moles de SMC por unidade de peso da amostra. A quantificação da SMC antes e após a hidrólise serviu para determinar a porcentagem de SMC livre existente na amostra.

2) Análise direta, comparando-se o tempo de retenção da SMC e do peptídeo $\gamma$-glutamilSMC, com os respectivos padrões sintéticos. O padrão do peptídeo sintético não existe comercialmente disponível, tendo sido sintetizado no laboratório de Bioquímica do Instituto de Química da USP; Para esta sintese contamos com a colaboração da Dra. Maria Thereza Macchini de Miranda. A identificação foi realizada por espectrometria de massa (Plasma desorption mass spectrometry (PDMS)) aplicada a biomoléculas não voláteis, em colaboração com os Doutores J.H. Hirata, K. Koide, E.L.A Macchione e S.S. Salém-Vasconcelos, do Laboratório de Partículas, do Instituto de Física da USP (REIS GIADA et al., 1998).

\subsection{Identificação e quantificação da metionina e da y-glutamil-L-metionina}

Foi realizada por análise indireta, após hidrólise ácida do peptídeo e medida da quantidade total da metionina em autoanalisador de aminoácidos. O tempo de hidrólise do EB foi limitado em 3 horas, tempo suficiente para hidrolisar o peptideo $\gamma$-glutamil-Lmetionina. (resultados não publicados)

As leituras de absorbância foram realizadas em $570+440 \mathrm{~nm}$. Os resultados foram expressos em $\mu$ moles de metionina por unidade de peso da amostra. A quantificação da metionina, antes e após a hidrólise, serviu para determinar a porcentagem de metionina livre existente na amostra. 


\subsection{Estabilidade da $\gamma$-glutamil-L-metionina durante o cozimento de sementes de Vigna mungo.}

Este experimento teve por objetivo avaliar a estabilidade do peptideo durante o cozimento caseiro do feijâo. Cerca de $200 \mathrm{~g}$ de sementes de Vigna mungo foram deixados de molho por 12 horas em $600 \mathrm{~mL}$ de água. A água de remolho foi separada e guardada, sendo que o feijão foi cozido com $500 \mathrm{~mL}$ de àgua em panela de pressão durante $30 \mathrm{~min}$ O feijăo cozido, o caldo de cozimento e a água de remolho foram secos em estufa ventilada a $40^{\circ} \mathrm{C}$, durante 24 horas

O feijão seco e o resíduo sólido do caldo e da água de remolho, foram submetidos a uma extração com etanol $70 \%$ para a obtenção da fração nitrogenada não protéica (EB), contendo o peptídeo $\gamma$-glutamil-L-metionina.

Partiu-se de $25 \mathrm{~g}$ de feijão cozido, seco e moído e $125 \mathrm{~mL}$ de etanol a $70 \%$, adotando-se um procedimento semelhante ao empregado para a extração do feijão cru (vide Figura 14). Devido à reduzida quantidade do resíduo sólido da água de remolho, todo o material, apesar do peso ser inferior a $25 \mathrm{~g}$, foi extraido com $125 \mathrm{~mL}$ de etanol $70 \%$, obtendo-se ao final do processo $25 \mathrm{~mL}$ de $\mathrm{EB}$. 


\section{Resultados e Discussão}

4.1 Efeito do plantio das sementes do Phascolus vulgaris L., em diferentes regiões sobre a concentração do peptídeo $\gamma$-glutamil-S-metil-L-cisteína e o a minoácido S-metil-L-cisteína.

Resultados obtidos em experimentos anteriores, evidenciaram a existência de um elevado teor de $y$-glutamil-SMC nas sementes do feijão Phaseolus vulgaris, L. A quantidade encontrada variou em até $68 \%$ entre cultivares da mesma espécie, provenientes de diferentes locais de cultivo dos Estados de São Paulo e do Paraná. No presente estudo tivemos como objetivo verificar se esta variação pode ser atribuida às diferenças de localização geográfica do plantio, aos câmbios ambientais do clima de um ano para o outro, ou se estas diferenças constituem uma característica genética das variedades de Phaseolus vulgaris L.

Apresentamos na Tabela 6, os resultados referentes aos teores protéicos e de umidade dos feijões. Estas análises foram necessárias para que os resultados referentes aos teores do peptídeo $\gamma$-glutamil-SMC e da SMC livre, pudessem ser convertidos de $\mu$ moles/g de feijão em base seca, para $\mu$ moles/g de proteina, com a finalidade de facilitar a comparação com experimentos futuros, ou com resultados publicados na literatura. As variedades Carioca e Iapar-14, foram cultivados em diferentes regiões do Estado do Paraná, com altitudes variando entre 400 e 893 m do nivel do mar. O fejjão Carioca foi cultivado em dois anos consecutivos, enquanto o feijăo lapar-14, apenas no primeiro ano (1997). 
Tabela 6: Conteúdo de umidade e proteína no feijão Phaseolus milgaris L., variedades Carioca e lapar-14, cultivadas em diversas regiões do Estado do Paraná.

\begin{tabular}{|c|c|c|}
\hline Regiões de plantio & Umidade \% (*) & $\begin{array}{c}\text { Proteína }(N \times 6,25) \\
\left(\% \text { base seca }{ }^{*}\right)\end{array}$ \\
\hline \multicolumn{3}{|l|}{ São João do Ivaí } \\
\hline Carioca ${ }^{(1)}$ & 11,43 & 20,85 \\
\hline Iapar-14 (1) & 11,33 & 22,16 \\
\hline Carioca ${ }^{(2)}$ & 14,48 & 17,64 \\
\hline Média & 12,41 & 20,22 \\
\hline \multicolumn{3}{|l|}{ Campo Mourāo } \\
\hline Carioca ${ }^{(1)}$ & 12,28 & 20,91 \\
\hline [араг-14 & 11,89 & 19,87 \\
\hline Carioca & 11,54 & 22,22 \\
\hline Média & 11,90 & 21,00 \\
\hline \multicolumn{3}{|l|}{ Wenceslau Braz } \\
\hline Carioca $^{(1)}$ & 11,78 & 20,29 \\
\hline Iapar-14 ${ }^{(1)}$ & 11,86 & 20,81 \\
\hline Carioca $^{(2)}$ & 11,51 & 22,76 \\
\hline Média & 11,72 & 21,23 \\
\hline \multicolumn{3}{|l|}{ Londring } \\
\hline Carioca ${ }^{(1)}$ & 12,30 & 22,19 \\
\hline Iapar-14 ${ }^{(1)}$ & 19,46 & 25,71 \\
\hline Carioca $^{(2)}$ & - & - \\
\hline Média & 15,88 & 23,95 \\
\hline \multicolumn{3}{|l|}{ Pato Branco } \\
\hline Carioca $^{(1)}$ & 11,88 & 22,70 \\
\hline Iapar-14 ${ }^{(1)}$ & 11,72 & 23,98 \\
\hline Carioca ${ }^{(2)}$ & 14,69 & 20,90 \\
\hline Média & 12,76 & 22,53 \\
\hline \multicolumn{3}{|l|}{ Irati } \\
\hline Carioca ${ }^{(1)}$ & - & - \\
\hline Iapar-14 ${ }^{(1)}$ & - & - \\
\hline Carioca $^{(2)}$ & 14,69 & 21,44 \\
\hline
\end{tabular}

(1) - Colheita na safra das águas - janeiro/1997

(2) Colheita na safra das águas - janeiro/1998.

$\left.{ }^{*}\right)$ - Média de 3 determinações. 
O teor protéico mostrou-se relativamente uniforme, variando entre 21,0 e $24,0 \mathrm{~g}$ proteína/l00 g de feijâo seco. Não foram verificadas diferenças significativas no teor protéico entre uma mesma variedade cultivada em regiões diferentes, nem entre o feijão Carioca cultivado em dois anos consecutivos. Os valores encontrados são semelhantes, em média, aos teores protéicos analisados anteriormente, por ocasião da análise de nove cultivares do feijão Phaseolus vulgaris, L. (24,2 $\pm 2,3 \mathrm{~g} / 100 \mathrm{~g}$ feijão seco), provenientes do Instituto Agronômico de Campinas e do Instituto Agronômico do Paraná. (BARROS, 1998). Os teores de proteina encontrados são semelhantes também, àqueles encontrados por outros autores, inclusive em variedades cultivadas em outros países. Um estudo amplo, abrangendo 57 cultivares de feijão (Phaseohus mlgaris L.) de procedência nacional, revelou que a concentração protéica variou entre 23,0 e $33,2 \mathrm{~g} / 100 \mathrm{~g}$ de fejjāo (SGARBIERI \& GALEAZZI, 1990). MONTI \& GRILLO (1983) em sua revisão sobre a variabilidade de conteúdo protéico das principais leguminosas comestiveis, reportam para o feijão comum, uma variação protéica entre 17 e 39,4\%.

Na Tabela 7 apresentamos os teores do peptídeo $\gamma$-glutamil-SMC e de SMC livre nos feijões cultivados nas diversas localidades. Preferimos expressar os resultados em umoles, ao invés de unidade de massa, uma vez que o massa molecular do peptídeo difere substancialmente da massa molecular da SMC livre. A soma dessas duas substâncias, quando expressa em umoles, fomece informação sobre o total de equivalentes de SMC presente na amostra.

O teor médio do peptídeo $\gamma$-glutamil-SMC, foi de 7,09 $\mu$ moles/g feijão base seca. As cultivares Carioca e Iapar-14 foram consideradas repetições do ensaio. Não foi observada relação com a região de cultivo, nem com o ano de plantio, sendo que a variação encontrada $(5,02$ a 8,51 umoles de $\gamma$-glutamil-SMC/g feijāo base seca), foi inferior até, à variação encontrada anteriormente, quando estudamos nove variedades de feijão Phaseolus vulgaris L provenientes dos Estados de São Paulo e do Paraná $(4,05$ a 12,59 $\mu$ moles de $\gamma$-glutamil-SMC /g feijão base seca) (REIS GIADA et al., 1998, BARROS, 1998). 
Em relação aos teores de SMC na forma livre, encontramos valores semeihantes para todas as regiões estudadas, correspondendo em média a 1,82 $\mu$ moles SMC/g feijão base seca, o que corresponde a $20,4 \%$ do total de equivalentes de SMC.

No estudo anterior, já mencionado, a porcentagem de SMC livre foi também semelhante, correspondendo a $24 \%$ da SMC total.

Com relação às condições climáticas dessas regiões de plantio e baseando-se em dados meteorológicos, segundo a classificação estabelecida por Köppen (Cartas Climáticas do Estado do Paraná, 1994), todas as regiões se enquadram na categoria Cfa: São regiões de clima subtropical, com temperatura média, no mês mais frio, inferior a $18^{\circ} \mathrm{C}$ e temperatura média, no mês mais quente, acima de $22^{\circ} \mathrm{C}$. Os verões sâo quentes, geadas pouco frequentes e tendência de concentração das chuvas nos meses de verăo, contudo sem estação seca definida. As regiões de Campo Mourão, Lond́rina e São João do Ivaí, são quentes, de solo fértil e argiloso, com cultivo predominante do feijão na safra das águas (semeadura de agosto a setembro) e eventualmente no outono (semeadura de fevereiro a março). Em Wenceslau Braz, o clima é mais ameno, solo mais pobre e mais leve; há predominância da saffa da seca. Pało Branco e Irati, mais a sudeste do Estado, os solos são férteis e clima quente, possuindo predominância de safra das águas.

Conclumos a partir deste ensaio e de outros anteriores, realizados ao longo de três anos, que os teores de $\gamma$-glutamil-SMC nas sementes são elevados, mas diferentes entre si Nos ensaios anteriores a este, foram analisadas sementes de Phaseohis vulgaris, L, provenientes do Estado de São Paulo. A variação encontrada não está relacionada com determinada variedade e também não pode ser explicada com base nas diferenças regionais do clima

Desta forma, o elevado teor de equivalentes de SMC encontrado por nós, confirmando dados de outros pesquisadores que encontraram teores semelhantes, parece ser uma característica comum, genotípica da espécie Phaseolus inılgaris L. 
Tabela 7: Teores de y-glutamil-S-metil-L-cisteina (y-glutamil-SMC) e de S-metil-L-cisteina (SMC) livre no feijão Phaseolus vulgaris L., variedades, Carioca e lapar-14. cultivadas em diversas regiões do Estado do Paraná.

\begin{tabular}{|c|c|c|c|c|}
\hline \multirow[t]{2}{*}{ Regiões de Plantio } & $\gamma$-glutamil-SMC + SMC & $\gamma$-glutamil-SMC ( $\left.{ }^{*}\right)$ & SMC livre $\left(^{*}\right)$ & $\%$ SMC livre \\
\hline & \multicolumn{4}{|c|}{$\mu$ moles/g feijão (base seca) } \\
\hline São João do Ivai & & & & \\
\hline Carioca ${ }^{(1)}$ & 8,77 & 6,54 & 2,23 & 25,43 \\
\hline [apar-14 & 10,82 & 8,37 & 2,45 & 22,64 \\
\hline Carioca $^{(2)}$ & 8,15 & 6,68 & 1,47 & 18,04 \\
\hline Média & 9,25 & 7,20 & 2,05 & 22,04 \\
\hline \multicolumn{5}{|l|}{ Campo Mourão } \\
\hline Carioca & 8,80 & 7,01 & 1,79 & 20,34 \\
\hline Iapar-14 (1) & 7,58 & 6,07 & 1,51 & 19,92 \\
\hline Carioca ${ }^{(2)}$ & 8,35 & 7,15 & 1,20 & 14,37 \\
\hline Média & 8,24 & 6,74 & 1,50 & 18,21 \\
\hline Wenceslau Braz & 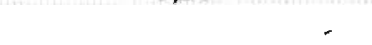 & & & \\
\hline Carioca ${ }^{(1)}$ & 9,75 & 6,85 & 2,90 & 29,74 \\
\hline lapar-14 (1) & 11,63 & 8,51 & 3,12 & 26,83 \\
\hline Carioca $^{(2)}$ & 8,08 & 6,48 & 1,60 & 19,80 \\
\hline Média & 9,82 & 7,28 & 2,54 & $25 ; 46$ \\
\hline \multicolumn{5}{|l|}{ Londrina } \\
\hline Carioca $^{(1)}$ & 8,29 & 6,75 & 1,54 & 18,58 \\
\hline Iapar-14 (1) & 9,80 & 8,10 & 1,70 & 17,35 \\
\hline Carioca (2) & 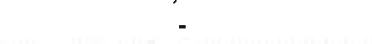 & - & - & - \\
\hline Média & 9,04 & 7,43 & 1,62 & $17 ; 96$ \\
\hline \multicolumn{5}{|l|}{ Pato Branco } \\
\hline Carioca $^{(1)}$ & 6,14 & 5,02 & 1,12 & 18,24 \\
\hline Iapar-14 & 7,95 & 6,33 & 1,62 & 20,38 \\
\hline Carioca $^{(2)}$ & 8,47 & 7,35 & 1,12 & 13,22 \\
\hline \multirow{2}{*}{\multicolumn{5}{|c|}{ Irati }} \\
\hline & & & & \\
\hline Carioca & - & - & - & - \\
\hline Iapar-14(1) & - & - & - & - \\
\hline Carioca ${ }^{(2)}$ & 9,55 & 7,66 & 1,89 & 19,79 \\
\hline
\end{tabular}

(2) - Colheita na safra das a auas - janeiro/1998.

(*) Quantificação por conparação com padrão sintetizado em laboratớrio e padrăo de S-metil-L-cisteina, respectivamente.

(**) Média de 3 determiną̧ỏes. 
4.2 Efeito do plantio do feijão Phaseolus vulgaris L., em solos com diferentes concentraçōes de enxofre sobre a concentração do peptídeo $\gamma$-glutamil-S-metil-Lcisteina e o aminoácido S-metil-L-cisteina.

Um outro experimento foi conduzido, avaliando-se o efeito da adição de enxofre suplementar ao solo sobre a concentração da $\gamma$-glutamil-SMC e sobre a concentração de SMC livre, na tentativa de explicar as variações observadas anteriormente.

De acordo com os rossos objetivos, as sementes de feijão foram plantadas em sulcos de 10 metros de comprimento com diferentes teores de enxofre. Da mesma forma, como no experimento anterior, foram analisados inicialmente os teores de umidade e de proteina.

Observamos na Tabela 8 que o teor protéico do feijão Phaseolus vulgaris, L, variedade Carioca, cultivado em condições controladas no Instituto Agronômico de Campinas, (IAC), foi superior a todos os teores protéicos até então encontrados nos feijões plantados nos Estados de São Paulo e do Paraná para essa mesma espécie de feijão. O teor protéico variou entre 29,2 e 31,4 g proteína/100 g semente seca. Entretanto, não foi observada nenhuma relação entre a concentração protéica nas sementes e o teor de enxofre no solo, fato que nos parece estar relacionado com a melhor qualidade deste solo, em relação a outros nutrientes, como por exemplo o $\mathrm{N}$, quando comparado aos solos em que os feijōes haviam sido cultivados nos experimentos anteriores.

A concentração protéica mais elevada numa mesma variedade de feijão parece ser decorrente de fatores ambientais, destacando-se a influência positiva da adubação nitrogenada, potássica e de enxofre, como foi demonstrado por pesquisadores do Instituto Agronômico de Campinas (IAC) (TANAKA et al., 1990, 1995; TANAKA \& MASCARENHAS, 1995)

Enquanto o efeito da adubação nitrogenada, potássica e de enxofre é bastante conhecido, atuando diretamente na síntese protéica durante a formação de sementes de leguminosas, especialmente se houver melhora na capacidade fotossintética e de fixação de nitrogênio pela simbiose com bactérias do gênero Rhizobium, pouco se conhece sobre o efeito da adubação com enxofre sobre a biossintese de compostos organossulfurados. 
No presente estudo avaliou-se o efeito da adição de quantidades crescentes de enxofte sobre a quantidade formada na semente do peptideo $\gamma$-glutamil-SMC e SMC na forma livre. Os resultados destas análises estão apresentados também na Tabela 8.

Tabela 8. Influência da adubação do solo com enxofre, nos conteudos do peptídeo $\gamma$ glutamil-S-metil-L-cisteína ( $\gamma$-glutamil-SMC) e de S-metil-L-cisteína (SMC) livre

\begin{tabular}{|c|c|c|c|c|c|}
\hline $\begin{array}{c}\text { Tratamento } \\
\text { (kg } \\
\left.\mathrm{CaSO}_{4} / \mathrm{ha}\right)\end{array}$ & $\begin{array}{l}\text { Proteína } \\
\mathrm{g} / 100 \mathrm{~g} \\
\text { semente } \\
\text { (base seca) }\end{array}$ & $\begin{array}{c}\gamma \text {-glutamil- } \\
\mathrm{SMC}^{\left({ }^{2}\right)}{ }^{+} \\
\mathrm{SMC}^{\left({ }^{\prime}\right)}\end{array}$ & $\begin{array}{l}\text { Y-glutamil- } \\
\text { SMC }\end{array}$ & $\begin{array}{c}\text { SMC } \\
\text { livre }^{\left({ }^{(}\right)}\end{array}$ & $\begin{array}{c}\% \mathrm{SMC} \\
\text { livre }\end{array}$ \\
\hline & & \multicolumn{4}{|c|}{$\mu$ moles/g feijão (base seca) ${ }^{(* *)}$} \\
\hline OS & 31,20 & 13,40 & 9,37 & 4,03 & 30,07 \\
\hline $7 \mathrm{~S}$ & 31,43 & 15,43 & 11,64 & 3,79 & 24,56 \\
\hline $14 S$ & 30,12 & 12,40 & 9,19 & 3,21 & 25,88 \\
\hline $28 \mathrm{~S}$ & 31,17 & 15,04 & 10,54 & 4,50 & 29,92 \\
\hline $56 \mathrm{~S}$ & 29,22 & 13,68 & 8,09 & 5,59 & 40,86 \\
\hline
\end{tabular}

Observamos que os teores de $\gamma$-glutamil-SMC e de SMC livre, eram superiores aos encontrados em quaisquer outras análises já realizadas anteriormente em sementes de feijâo comum, não havendo relação entre o nível de adição de enxofre ao solo e a concentração dos compostos sulfurados na semente.

Os teores do peptídeo e de SMC livre variaram entre 9,19 e $11,64 \mu$ moles e 3,21 e $5,59 \mu \mathrm{moles} / \mathrm{g}$ de feijão seco, respectivamente. A concentração de SMC livre em relação ao peptídeo também foi superior, correspondendo a uma média de 30,3\% do total de equivalentes de SMC ( $\gamma$-glutamil-SMC + SMC livre) na amostra. 
Pelo fato de não termos observado mudanças nos teores da $\gamma$-glutamil-SMC e da SMC em resposta ao tratamento do solo com enxofre, suspeitamos haver, no entanto, uma relação entre a síntese dos compostos sulfurados e a síntese protéica. Esta hipótese apoiaria as evidências reportadas na literatura, do peptídeo $\gamma$-glutamil-SMC constituir uma forma orgânica de reserva de $\mathrm{N}$ e de $\mathrm{S}$, estando acoplado ao processo de síntese protéica (KASAI et al., 1982; FENWICK \& HANLEY, 1985; CECl et al, 1992).

Assim, calculou-se a concentração do peptideo $\gamma$-glutamil-SMC e da SMC livre por grama de proteína presente no feijão. Estes resultados estão apresentados na Tabela 9. A título de comparação apresentamos nesta mesma tabela resultados referentes aos ensaios realizados anteriormente. Constatamos que o teor do peptideo $\gamma$-glutamil-SMC, que em valor absoluto se havia mostrado mais elevado no experimento com solo enriquecido com enxofre, apresentou uma relação constante com a concentração protéica do feijão, em todos os ensaios já realizados. Estes ensaios foram três:

1) Diferentes variedades de feijão comum, cultivadas em diferentes épocas e em diferentes localidades.

2) Variedades Carioca e Iapar-14, cultivadas em dois aros consecutivos.

3) Variedade Carioca, cultivada em solo com adição de enxofre. 
Tabela 9. Influência da variedade, região de cultivo e adição de enxofre no teor do peptídeo $\gamma$-glutamil-S-metil-L-cisteina ( $\gamma$-glutamil-SMC) e S-metil-L-cisteina (SMC) livre.

\begin{tabular}{|c|c|c|c|}
\hline \multirow[t]{2}{*}{ Feijōes } & $\begin{array}{c}\text { Proteina g/100g } \\
\text { semente } \\
\text { (base seca) }\end{array}$ & $\begin{array}{l}\gamma \text {-glutamil- } \\
\text { SMC }\end{array}$ & SMC livre \\
\hline & \multicolumn{3}{|c|}{ «moles/g feijāo (base seca) } \\
\hline $\begin{array}{l}\text { Variedades de reijão Phaseolus vulgaris } \\
\text { L., cultivados em diferentes épocas. }\end{array}$ & & . & \\
\hline Safira & 25.17 & 30,79 & 7,83 \\
\hline Pintado & 20,30 & 19.95 & 24,24 \\
\hline Carioca & 23,38 & 42,26 & 11,38 \\
\hline Iapar-14 & 23,86 & 40,86 & 13,24 \\
\hline Iapar -57 & 24.79 & 45,26 & 10,77 \\
\hline Iapar-3 I & 23,56 & 28,10 & 1,53 \\
\hline Iapar-16 & 21,71 & 26,30 & 9,40 \\
\hline Iapar-8 & 27,52 & 26,38 & 9,63 \\
\hline Maravilha & 27,14 & 46,39 & 10,69 \\
\hline Média & 24,16 & 34,03 & 10,97 \\
\hline
\end{tabular}

Feijāo Phaseolus vulgaris L., variedades Carioca e Iapar-14, cultivadas em dois anos consecutivos.

\begin{tabular}{|c|c|c|c|}
\hline São João do Ivaí & 20,22 & 36,81 & 10,03 \\
\hline Campo Mourão & 21,00 & 32,74 & 7,19 \\
\hline Wenceslau Braz & 21,23 & 36,82 & 12,10 \\
\hline Londrina & 23,95 & 30,95 & 6,78 \\
\hline Pato Branco & 22,53 & 24,16 & 5,68 \\
\hline Irati & 21,44 & 29,83 & 8,81 \\
\hline Média & 21,73 & 31,89 & $8 ; 43$ \\
\hline \multicolumn{4}{|c|}{$\begin{array}{l}\text { Feijão Phaseolus vulgaris } \mathrm{L} \text {., variedade } \\
\text { Carioca: adição de enxofre no solo (kg } \\
\mathrm{CaSO}_{4} \text { ha). }\end{array}$} \\
\hline $0 \mathrm{~S}$ & 31,20 & 30,03 & $\mathrm{~J} 2,93$ \\
\hline $7 \mathrm{~S}$ & 31,43 & 37,03 & 12,04 \\
\hline $14 \mathrm{~S}$ & 30,12 & 30,52 & 10,64 \\
\hline $28 \mathrm{~S}$ & 31,17 & 33,83 & 14,45 \\
\hline $56 \mathrm{~S}$ & 29,22 & 27,67 & 19,12 \\
\hline Média & 30,63 & 31,82 & 13,84 \\
\hline
\end{tabular}


Para melhor esclarecer os resultados deste estudio e determinar o mecanismo intrínseco que pudesse estar a eles relacionados, procuramos na literatura, acerca do efeito da adubação sobre a sintese protéica e de compostos organossulfurados (LABANAUSKAS et al., 1981.).

O processo de assimilação do sulfato no cloroplasto é dependente de ATP e da enzima FAD, que são sintetizados durante o processo de fotossíntese, dando origem à cisteina. A adição do ácido glutâmico resulta na GSH, que constitui um carregador orgânico do sulfato. Sabendo-se que a enzima glutationa redutase também se localiza no cloroplasto e que a redução da GSSG (glutationa oxidada) depende da presença de luz, a própria capacidade fotossíntetica poderá regular a assimilação do sulfato em função da disponibilidade da glutationa na forma reduzida (ANDERSON, 1980).

Poucos estudos existem na literatura relacionando a biossíntese de compostos organossulfurados nos vegetais, em especial nas leguminosas comestiveis. A biossintese destes compostos é estudada um pouco mais a fundo, nos vegetais da familia Cruciferae, em especial nas sementes de colza (Brassica napus), devido à sua importância econômica como fonte protěica em rações animais e produção de óleos para diversas finalidades.

Para um desenvolvimento adequado, esta semente oleaginosa exige um solo com elevado teor de enxofre, que é então acumulado e retido na planta na forma de sulfato. Apesar da colza necessitar de solo rico em enxofre, este vegetal, e outros da família Cruciferae, não é eficaz na conversão do $\mathrm{SO}_{4}{ }^{2 \cdot}$ para substâncias organossulfuradas. Sob ponto de vista quantitativo, ao redor de $8 \%$ do enxofre total da semente encontra-se na forma de glicosinolatos, aproximadamente $25 \%$ na forma do peptideo $\gamma$-glutamil-SMC e de SMC livre, sendo o restante encontrado na forma de sulfato. O fornecimento de enxofre em quantidades superiores ao desenvolvimento ideal da planta, não aumenta o teor de glicosinolatos na semente, mas o excesso de enxofre pode ser encontrado na forma de sulfato nas paredes das vagens das sementes. As variedades de colza com reduzido teor de glicosinolatos e ácido enúcico, denominadas duplo zero, assimilam a mesma quantidade de enxofre, demonstrando de certa forma que a biossintese é regulada pela enzima e a expressão dos genes correspondentes (ZHAO et al., 1993; WALLSGROVE, 1999). 
Da mesma forma, os resultados observados em nossos estudos indicam que a variação nos teores do peptídeo $\gamma$-glutamil-SMC e da SMC livre, nos feijões Phaseohis rulgaris L., cultivados em solos com diferentes concentrações de enxofre,não é dependente do teor enxofre no solo. Parece existir uma relação constante entre a proteina formada, a concentração do peptídeo $\gamma$-ghutamil-SMC e a SMC livre. A síntese protéica, por sua vez, encontra-se regulada pela capacidade de assimilação de rutrogênio inorgânico pela planta e a sua capacidade de realizar fotossíntese

A essa altura nos parece oportuno propor um mecanismo de biossintese e de regulação do peptídeo e da SMC livre, aplicável às sementes de leguminosas da espécie Phaseolus inlgaris L., que passarernos a apresentar.

Acreditamos que a síntese protéica nas sementes de leguminosas é acompanhada da sintese do peptídeo $\gamma$-glutamil-SMC, que irá servir temporariamente como substância de reserva de $\mathrm{N}$ e de S, já na forma orgânica de ácido glutâmico e de SMC, fazendo parte da "linha de montagem" da proteína. Esta parece ser a única maneira de armazenar uma grande quantidade de S orgânico na semente, uma vez que a proporção N:S é de $1: 1$ na SMC livre e de 2:1 na $\gamma$-glutamil-SMC, relação esta, muito superior à encontrada na proteína, que sabidamente é pobre em S. Este ácido glutâmico contido no peptídeo, poderia ser rapidamente tornado disponivel para a síntese protéica, quando ocorrer a germinação da semente, pela ação hidrolítica da enzima $y$-GT. Neste caso, haveria liberação concomitante da SMC livre, que por sua vez, seria reaproveitada através da reação enzimática de transpeptidação, pela mesma $\gamma-\mathrm{GT}$, formando nova molécula de $\gamma$ glutamil-SMC. Esta hipótese é apoiada pelos seguintes argumentos

1) O teor do peptideo $\gamma$-glutamil-SMC, foi proporcional ao teor protéico na semente, em todos os ensaios realizados, ind́ependente da qualidade do solo. Isto é, condições climáticas e de solo que favoreceram menor síntese protéica, também resultaram em quantidades menores do peptídeo; condições mais favoráveis de solos e clima, proporcionaram quantidades maiores de proteína e do peptídeo (vide Tabela 9).

2) O teor de SMC livre foi ligeiramente superior quando o solo onde o feijão cresceu, estava fartamente adubado com nitrogênio, estimulando a síntese protéica, no entanto, o enxofre não pareceu ser um fator limitante, uma vez que a concentração de 
SMC livre e do peptídeo não foi influenciada pelo teor de $\mathrm{S}$ no solo (vide Tabelas 4,7 e 8).

3) Durante os primeiros quatro dias de germinação do feijão, ocorreu um desaparecimento gradativo do peptideo, sem contudo haver um aumento concomitante nos teores de ácido glutâmico e de SMC livte. O teor protéico da semente também sofreu um decréscimo neste mesmo periodo, indicando intenso processo de metabolização. No $5^{\circ}$ dia observamos um aumento no teor protéico e de todos os aminoácidos livres, incluindo a SMC e o seu respectivo $\gamma$-glutamil peptídeo, devido ao início do processo de fotossíntese da plântula (vide Figuras 9 e 10).

4) De acordo com os dados da literatura, não parecem existir em leguminosas, enzimas capazes de degradar a $y$-glułamil-SMC ou a SMC na direção dos produtos encontrados nos vegetais das famílias Alliaceae e Cruciferae. Assim, sendo, os efeitos fisiológicos benéficos, comprovados em mamiferos e em humanos, atribuídos aos produtos de metabolização das substâncias sulfuradas nestas duas famílias, não foram e não serão observadas em leguminosas.

5) A hipótese da $\gamma$-glutamil-SMC e da SMC livre atuarem como substâncias de defesa da planta contra insetos não foi confirmada, observando-se que o feijão comum não foi poupado pelos insetos que costumam atacar estes grãos (SHEPARD et al., 1983).

Na Figura 16 apresentamos o mecanismo proposto para a biossíntese e metabolização da $\gamma$-glutamil-SMC e da SMC em sementes de Phaseolus vulgaris L. 


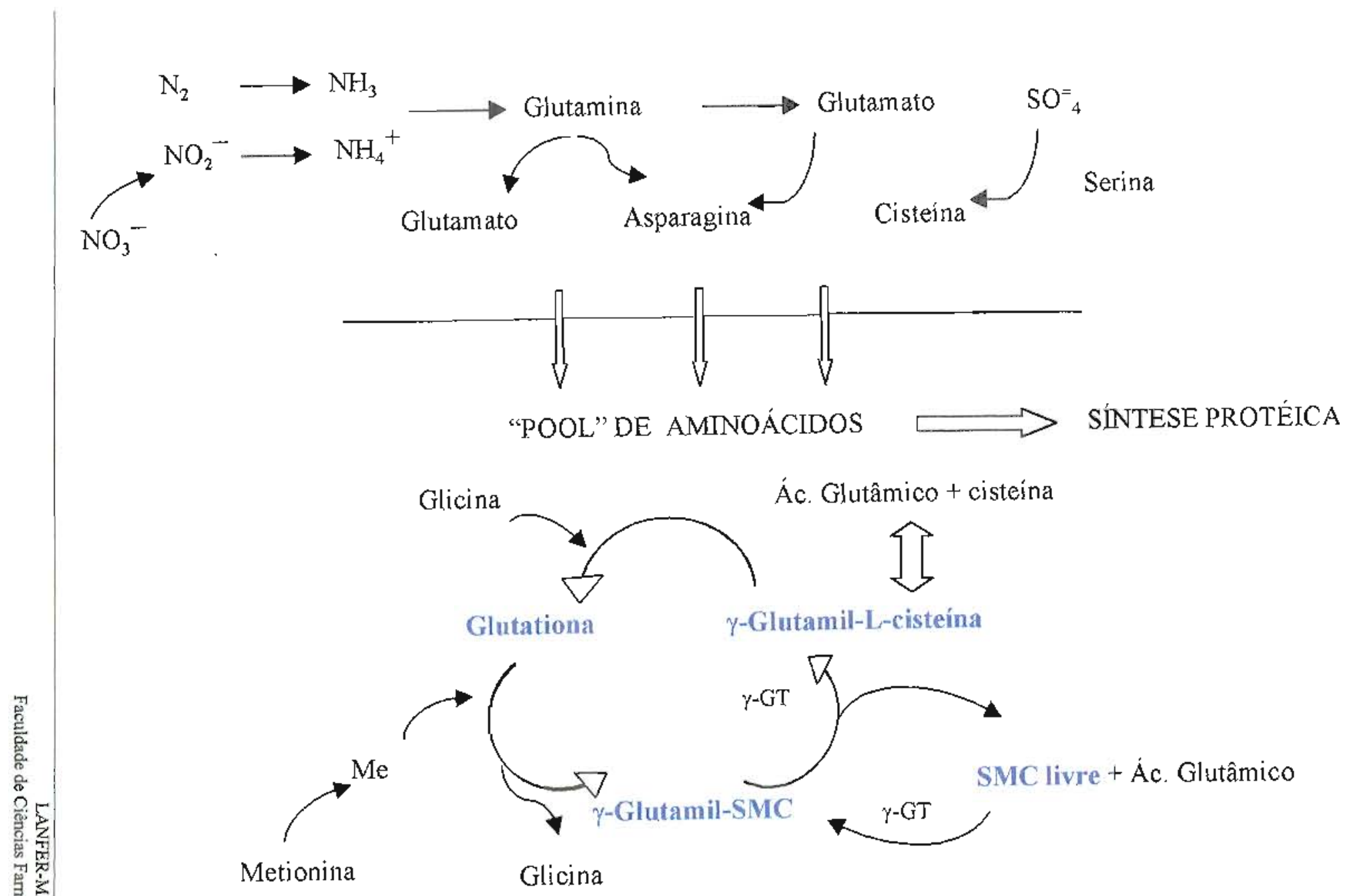

Figura 16. Mecanismo proposto para a biossintese e metabolização do peptideo $\gamma$-glutamil-S-metil-L-cisteina e da S-metil-L-cisteina livre em leguminosas 
4.3 Sementes de Vigna mungo (L.) Bepper e Vigna radiata (L.), R. Wiliczek, como alternativa ao consumo do habitual feijão Phaseolus vulgaris, $L$.

O grupo Vigna é composto por duas espécies de leguminosas: a Vigna radiata e a Vigna mungo. Morfologicamente estas duas espécies são muito parecidas entre si, sendo de dificil distinção. A Vigna radiata é conhecida como "green gram", por apresentar a casca de cor esverdeada. A Vigna mungo, denominada de "black gram", apresenta usualmente uma casca escura, quase preta. Mas, a dificuldade para diferenciá-las persiste, porque freqüentemente ocortem variações na tonalidade de cores: a semente de Vigna mungo às vezes assume cor esverdeada. É esta a razão destas duas espécies serem agrupadas e denominadas com freqüencia "complexo Vigna mungo/radiata". A Figura 17 mostra a fotografia das sementes das duas espécies.

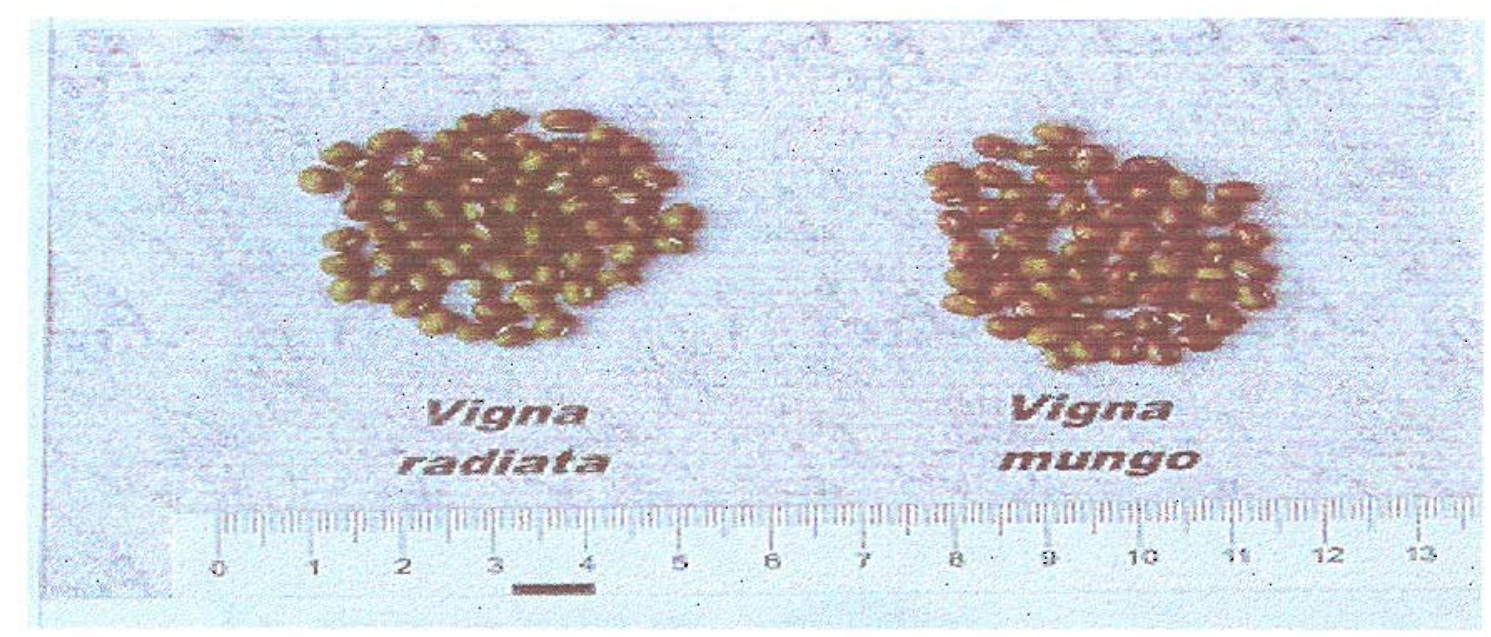

Figura 17. Morfologia das sementes Vigna radiata e Vigna mungo.

Outra questão importante está relacionada com a classificação taxonômica das espécies do grupo Vigna. Este grupo, pertencia originalmente ao gênero Phaseolus, tendo sido classificada a Vigna radiata como Phaseolus radiata L., ou mesmo como Phaseolus ciureus, Roxb., enquanto a Vigna mungo, como Phaseolus mungo (VERCOURT, 1970, citado por SAVAGE \& DEO, 1989). Até hoje, a referência destas duas espécies vem causando confusão na literatura, porque os seus nomes são usados como sinônimos. 
Causa estranheza também, que a Vigna radiata, venha sendo denominada "mung bean", o que intuitivamente remete ao nome cientifico Vigna mungo.

Portanto, não chamá-las pelos nomes populares é uma maneira de diferenciar as espécies de Vigna entre si (BISBY et al., 1994). Quimicamente elas podem ser diferenciadas pela presença de $\gamma$-glutamil-peptideos sulfurados diferentes. A $\gamma$-glutamilL-metionina caracteriza as sementes de Vigna mungo, enquanto as da espécie da Vig7ia radiata não contêm este peptideo, mas apresentam em grande quantidade a $\gamma$-glutamîSMC (KASAI et al., 1986).

Apresentamos na Tabela 10 a composição química comparativa entre as sementes Vigna mungo e Vigna radiata. Observa-se que a diferença nos teores de umidade, cinzas, lipideos e proteinas é pequena entre as duas espécies. O conteúdo proteico também é similar $(28 \%)$, situando-se na mesma faixa de concentração encontrada no feijāo comum (Phaseolus vulgaris, L.) O teor de lipídeos é de 1,2\%, o resíduo mineral varia entre 3,8 e $3,9 \%$ e o conteúdo de carboidratos equivale a aproximadamente $50 \%$ do peso do feijâo, considerando a umidade ao redor de $9 \%$, em média.

Estes resultados encontrados, aproximam-se aos teores citados por outros autores (RAGHUVANSHI et al., 1993, 1997; MAHAJAN et al., 1988).

Mesmo apresentando um conteúdo protéico parecido, sugerindo um valor nutricional semelhante, as duas espécies mostram diferenças em relaçăo aos teores de fibra e à sua distribuição entre a fração solúvel e insolúvel. A Vigna mungo e a V'igna radiata possuem um teor elevado de fibra, embora diferentes para as duas espécies $21 \%$ na Vigna mungo e 15\% na Vigna radiata, sendo a participação da fibra insolúvel de $67 \%$ e $82 \%$ em relação à fibra total, respectivamente. A literatura menciona valores entre 4 e $31 \%$, possivelmente devido à metodologia utilizad́a (KAUR \& KAPOOR, 1992, RAGHUVANSHI et al., 1997; CHITRA et al., 1994; GOONERATHE, 1994; BRAVO et al., 1999). O elevado teor de fibra encontrado repercutiu no tempo de cozimento 87 e 67 min, em panela comum, para a $V$. mungo e $V$. radiata respectivamente. 
Tabela 10. Composição centesimal dos feijões das espécies Vigna mungo e Vigna radiata.

\begin{tabular}{|c|c|c|}
\hline \multirow[t]{2}{*}{ Composição } & Vigna mungo & Vigna radiara ${ }^{a}$ \\
\hline & \multicolumn{2}{|c|}{ g/l00 g de feijão (base seca) } \\
\hline Umidade & $9,60 \pm 0,21$ & $8,38 \pm 0,29$ \\
\hline Cinzas & $3,76 \pm 0,03$ & $3,85 \pm 0,03$ \\
\hline Proteina & $27,52 \pm 0,18$ & $27,94 \pm 0,40$ \\
\hline Lipideos & $1,18 \pm 0,11$ & $1,17 \pm 0,29$ \\
\hline $\begin{array}{l}\text { Fibra total } \\
\text { Solúvel } \\
\text { Insolúvel }\end{array}$ & $\begin{aligned} 21,15 & \pm 0,58 \\
6,90 & \pm 0,35 \\
14,25 & \pm 0,23\end{aligned}$ & $\begin{array}{r}14,81 \pm 0,50 \\
2,60 \pm 0,28 \\
12,21 \pm 0,22\end{array}$ \\
\hline Carboidratos $^{b}$ & 46,39 & 52,23 \\
\hline Calorias (Kcal/100 g) & 306,26 & 331,21 \\
\hline
\end{tabular}

(a) Média de 3 determinações.

(b) (b) Calculados por diferença

Na Tabela 11 apresentamos a composição de aminoácidos das duas espécies de Vigna analisadas. Ambas as espécies são ricas em ácido glutâmico e ácido aspártico, fato comum em leguminosas; os demais aminoácidos guardam semelhança com o perfil apresentado pelos feijões da espécie Phaseohus milgaris, L., excetuando-se o teor de metionina que se encontra significativamente mais elevado nas sementes de Vigna mingo. 
Tabela 11. Composição de aminoácidos das farinhas de feijões das espécies Vigna mungo e Vigna radiata.

\begin{tabular}{|c|c|c|}
\hline \multirow[t]{2}{*}{ Aminoácidos } & Vigna mungo & Vigna radiala \\
\hline & \multicolumn{2}{|c|}{$\mathrm{g} a \mathrm{a} / \operatorname{logg} \mathrm{P}^{* * *}$} \\
\hline Acido aspártico & $12,37 \pm 0,75$ & $11,93 \pm 0,27$ \\
\hline Treonina & $3,27 \pm 0,18$ & $3,19 \pm 0,13$ \\
\hline Serina & $5,13 \pm 0,11$ & $4,75 \pm 0,12$ \\
\hline Ácido glutâmico & $17,95 \pm 0,98$ & $18,68 \pm 0,45$ \\
\hline Prolina & $5,17 \pm 1,54$ & $6,74 \pm 1,47$ \\
\hline Glicina & $4,15 \pm 0,37$ & $4,14 \pm 0,15$ \\
\hline Alanina & $4,59 \pm 0,07$ & $4,64 \pm 0,15$ \\
\hline Cisteína* & $1,32 \pm 0,11$ & $1,16 \pm 0,05$ \\
\hline Valina & $5,47 \pm 0,06$ & $5,33 \pm 0,50$ \\
\hline Metionina** & $2,68 \pm 0,28$ & $1,87 \pm 0,01$ \\
\hline Isoleucina & $4,35 \pm 0,18$ & $4,23 \pm 0,55$ \\
\hline Leucina & $8,63 \pm 0,07$ & $8,23 \pm 0,62$ \\
\hline Tirosina & $2,68 \pm 0,03$ & $2,67 \pm 0,43$ \\
\hline Fenilalanina & $6,14 \pm 0,07$ & $6,01 \pm 0,44$ \\
\hline Histidina & $2,41 \pm 0,13$ & $2,41 \pm 0,35$ \\
\hline Lisina & $7,00 \pm 0,11$ & $7,23 \pm 0,39$ \\
\hline Arginina & $6,69 \pm 0,17$ & $6,78 \pm 0,23$ \\
\hline
\end{tabular}

$\left.{ }^{*}\right)$ - calculado como ácido cistéico

(**)- calculado como sulfona de melionina

$\left({ }^{* * *}\right)$ - média de 3 determinaçoos

O teor de metionina na Vigna mungo $(2,87 \mathrm{~g} / 100 \mathrm{~g}$ proteina), foi $30 \%$ superior ao obtido na Vigna radiala (1,87\%/100 g proteina), sendo aquele valor o mais elevado já encontrado em sementes de leguminosas. Comparando-se estes resultados com a Tabela da FAO/WHO, 1991, referente às necessidades em aminoácidos essenciais, para crianças 
de 3 a 8 anos, mostra que a Vigna radiata é deficiente em aminoácidos sulfurados, como acontece com outras sementes de leguminosas comestíveis.

Já em 1975, OTOUL e colaboradores, observaram um teor de 1,58 e 1,15\% de metionina nas espécies $V$. mungo e $V$. radiata, respectivamente, dando uma diferença de aproximadamente $27 \%$ entre as duas espécies. O fato destes autores terem encontrado um valor menor, está possivelmente relacionado com o procedimento utilizado para a hidrólise da proteina, que não incluiu uma estabilização da metionina e da cisteina, por oxidação com ácido perfórmico (MOORE, 1963).

O teor elevado de metionina, encontrado nas sementes de Vigna mungo, suporta a hipótese de que uma parte da metionina, na Vigna mungo, seja proveniente do peptídeo $\gamma$ glutamil-L-metionina encontrado nessa espécie de leguminosa.

Apresentamos na Figura 18 (A e B), os perfis dos Exiratos Brutos (EB) obtidos da extração das sementes Vigna mungo e Vigna radiata., onde constatamos e confirmamos dados da literatura, apontando para a importância quimiotaxonômica dos dois peptídeos.

Como já era esperado, após a hidrólise ácida, estes peptídeos desapareceram, causando um aumento da metionina, da SMC e do ácido glutâmico (Figura 19 (A e B)).

Enquanto o peptídeo $\gamma$-glutamil-S-metil-L-cisteína, presente na Vigna radiata, possui na sua estrutura molecular um aminácido sulfurado não protéico, que não pode ser utilizado nutricionalmente, o peptideo y-glutamil-L-metionina presente nas sementes de Vigna mungo, poderia ao menos teoricamente, contribuir com o aumento do conteúdo total de metionina na semente. Este fato, seria importante do ponto de vista do valor nutricional desta espécie, em detrimento da outra. 


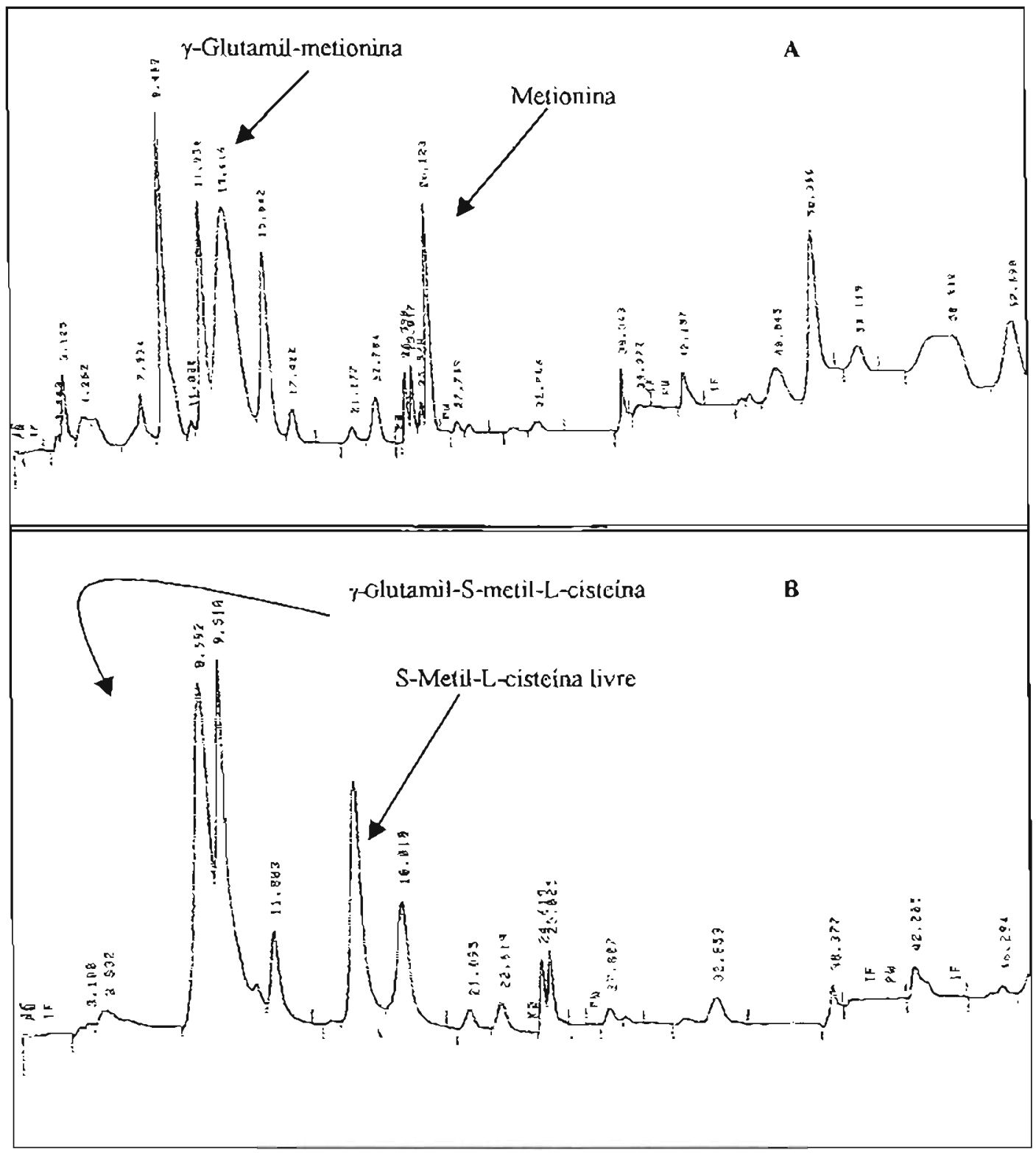

Figura 18. Aminograma dos extratos brutos não hidrolisados de Vigna mungo Cultivar Preto (A) e Vigna radiata (B). 
$\gamma$-Glutamil-metionina
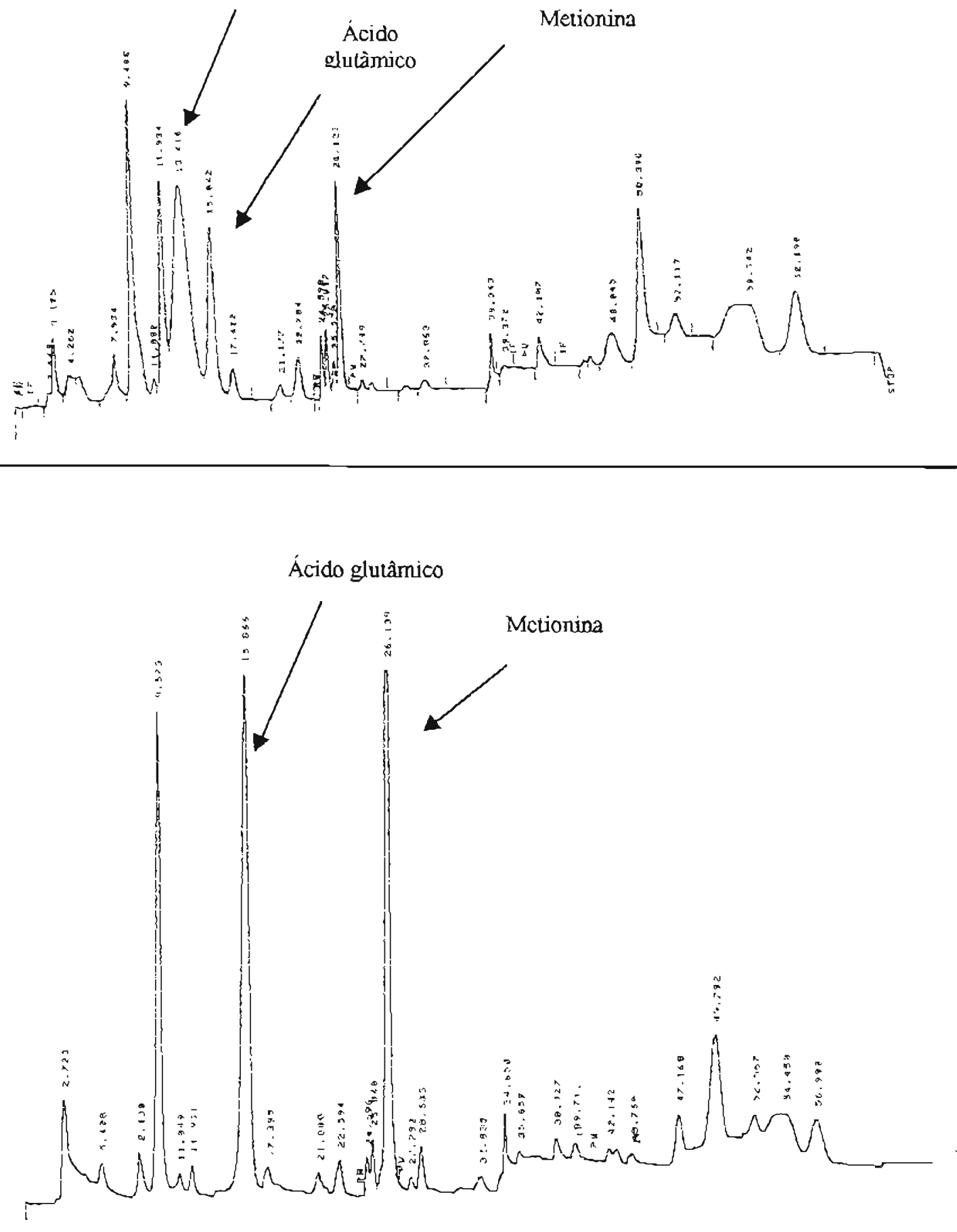

Figura 19 Extrato bruto nāo hidrolisado (A) e extrato bruto hidrolisado (B) da Vigna mungo - cultivar Preto 
Em $100 \mathrm{~g}$ do feijão cru encontramos $27,5 \mathrm{~g}$ de proteina e $740 \mathrm{mg}$ de metionina total, que corresponde à soma da metionina protéica com a metionina livre e a $\gamma$-glutamilL-metionina. Estes $740 \mathrm{mg}$ de metionina/100 g feijão, correspondem a 2,68 g de metionina/100 g de proteina

No EB da farinha deste mesmo fejjão, encontramos $255 \mathrm{mg}$ de $\gamma$-glutamil-Lmetionina + metionina livre/100 g de feijão. Este teor, quando comparado à quantidade total de metionina, corresponde a $34,5 \%$.

Assim, o elevado teor de metionina encontrado nesta espécie de feijão, não significa que a proteína deste contenha um maior teor de metionina em sua composição: descontando-se do teor de metionina total, 34,5\% que corresponde ao peptídeo e à metionina livre, a quantidade de metionina de origem protéica passa de 2,68 para 1.74 g/100 g de proteina; valor este, que não é muito superior ao encontrado em outras sementes de leguminosas comestíveis.

Para conhecer melhor o comportamento do peptídeo $\gamma$-glutamil-L-metionina, durante o cozimento dos grãos de Vigna mungo, mantivemos os grãos de remolho por 12 horas. Após este tempo, cozinhamos o feijão até atingir maciez, extraímos a fração nitrogenada não protéica (EB) e analisamos separadamente, a água de remolho, o caldo do feijão e o feijão cozido e escorrido. Este experimento foi realizado com a finalidade de verificar se o peptídeo era solubilizado e se difundia para a água de remolho, ou se o mesmo mantinha-se intacto no feijão, ou então, no seu caldo de cozimento.

Os resultados encontrados mostraram não haver passagem do peptídeo, nem da metionina livre, para a água de remolho. No entanto, o caldo do feijão e o feijão cozido, continham quantidades variáveis do peptídeo, embora nas duas repetições realizadas, a soma do peptídeo intacto, presente no caldo e no feijão, fosse exatamente a mesma. Estes resultados indicam que a distribuição relativa do peptídeo, entre o feijāo e o seu caldo, varia possivelmente em decorrència da relação entre o feijão e a quantidade de água utilizada para o cozimento. Uma outra hipótese estaria relacionada com a dificuldade de solubilização do peptídeo em função do tempo e da temperatura de armazenamento das sementes

No EB do feijão cru encontramos $255 \mathrm{mg}$ de metionina/lo0g de feijāo, enquanto os EB's do feijão cozido + caldo continham somente $156 \mathrm{mg}$ de metionina/lo0 $\mathrm{g}$. 
A quantidade de $156 \mathrm{mg}$ de metionina corresponde a uma recuperação de $61 \%$ da metionina após o cozimento. Até este momento, desconhecemos se os $39 \%$ do peptídeo $\gamma$-glutamil-L-metionina + metionina livre, foram degradados, ou se não foram adequadamente extraídos durante a obtenção dos EB's do feijão cozido.

Em relação a possibilidade de absorção intestinal e metabolização da $\gamma$-glutamilL-metionina, estamos propondo uma analogia com o peptídeo $\gamma$-glutamil-SMC, por nos estudado em trabalho anterior (PADOVESE et al, aceito para publicação) Observou-se para a $\gamma$-glutamil-SMC, uma hidrólise enzimática a nivel intestinal, tendo aparecido no sangue periférico apenas a SMC livre. De acordo com estes resultados, acreditamos poder extrapolar para a $\gamma$-glutamil-metionina, a hidrólise a nível intestinal sofrida pela $\gamma$ glutamil-SMC. Neste caso, a metionina resultante da hidrólise, seria indistingüivel da metionina oriunda da hidrólise de uma proteína, que então poderá ser utilizada nutricionalmente. 


\section{Conclusões}

1) O feijāo Phaseolus vulgaris L., variedades Carioca e Iapar-14, cultivadas em seis localizadas do Estado do Paraná, em dois anos consecutivos, apresentou teores elevados do peptídeo $\gamma$-glutami\}-SMC e da SMC livre. A ordem de grandeza foi de 8,90 umoles equivalentes de $\mathrm{SMC} / \mathrm{g}$ de fejjäo seco), correspondendo à soma do peptídeo + SMC livre. A variação, dentro desta média, foi de 6,14 à 11,63 umoles/g de feijão seco. A participação da SMC livre foi uniforme nas seis localidades de cultivo, sendo da ordem de $20 \%$, em média, em relação ao total de equivalentes de SMC presente nas amostras Os teores elevados destas substâncias, indicam ser uma caracteristica comum genotipica da espécie Phaseolus vulgaris L .

2) As variações encontradas nos teores elevados de $\gamma$-glutamil-SMC e de SMC livre, nos feijões Phaseolus vulgaris L, variedades Carioca e lapar-14, cujtivados em diferentes localidades, não foram dependentes da regiāo de cultivo, nem do ano da safra, nem das condiçōes atmosféricas regionais.

3) A adubação de um solo rico em nutrientes, com concentrações crescentes de enxofre, não influenciou os teores do peptídeo $\gamma$-glutamil-SMC e de SMC livre no feijão Phaseolus vulgaris L.

4) Os teores do peptideo $\gamma$-glutamil-SMC e de SMC livre foram proporcionais à concentração protéica no feijão, independente da qualidade do solo, existindo uma relação constante que parece estar relacionada com a sintese protéica.

5) Os resultados obtidos sugerem que a sintese protéica está acoplada à síntese do peptídeo, que irá servir temporariamente de substância de reserva de $\mathrm{N}$ e de $\mathrm{S}$, fazendo parte da "linha de montagem" da proteina. O peptídeo seria uma forma de armazenamento de $\mathrm{N}$ e $\mathrm{S}$, podendo ser mobilizada rapidamente por ocasiāo da germinação da semente 
6) A análise química do feijão "Vigna mungo" mostrou que estas sementes possuem uma composição química semelhante a outras leguminosas, caracterizando-se pelo elevado teor protéico ( $28 \%$ no feijão seco) e de metionina $(2,68 \mathrm{~g} / \mathrm{l} 00 \mathrm{~g}$ proteína). Esta espécie é dificilmente diferenciada da Vigna radiata, pelo fato das sementes possuírem morfologia e coloração semelhantes. A presença do peptideo $\gamma$-glutamil-metionina na Vigna mungo e do peptídeo $\gamma$-glutamil-SMC na Vigna radiata, distingue químicamente estas duas espécies.

7) O elevado teor de metionina $(2,68 \mathrm{~g} / 100 \mathrm{~g}$ de proteína) encontrado nas sementes de Vigna mungo corresponde à soma da metionina inserida nas proteinas, da metionina contida no peptideo $\gamma$-glutamil-metionina e da metionina encontrada na forma livre. A metionina de origem não protéica, contribui com $34,5 \%$ do total de metionina encontrada neste feijão. 


\section{Resumo}

Os compostos organossulfurados, representados pelos peptídeos $\gamma$-glutamilsulfurados, são encontrados em grande quantidade em vegetais das famílias Alliaceae, Cruciferae e Leguminosae. A seus produtos de metabolização se atribui propriedades organolépticas típicas e quando são ingeridos por mamiferos, causam efeitos biológicos diversos. Estes efeitos são diferentes nestas três famílias, devido à formação de metabólitos secundários que dependem da presença ou ausência de enzirnas especificas nestes vegetais. Na familia Alliaceae, representada pelo alho e pela cebola, são produzidos compostos sulfurados, que além de serem precursores de aroma e de flavor característicos após a ruptura do tecido vegetal e a ação enzimática, se tornaram conhecidos pelos efeitos benéficos para a saúde humana. A via metabólica percorrida pelos compostos organossulfurados na familia Cruciferae, dá origem, além do flavor, a compostos secundários diversos, incluindo o metanotiol e dissulfetos, altamente tóxicos para ruminantes, causando anemia hemolítica. Na família Leguminosae, os dipeptídeos sulfurados são encontrados principalmente nas sementes, sendo que o feijão Phaseolus nulgaris, L., dentre os gêneros estudados, os possui em maior concentração. A $\gamma$-glutamilS-metil-L-cisteína e a S-metil-L-cisteina livre, podem em conjunto, representar até $50 \%$ do conteúdo total de metionina presente no feijão, desaparecendo somente por ocasião da sua germinação. O cozimento do feijão não degrada estas substâncias que, quando ingeridas são hidrolisadas e absorvidas, aparecendo no sangue periférico já na forma de S-metil-L-cisteína livre. Os processos de metabolização da S-metil-L-cisteína e da metionina são diferentes, apesar da semelhança estrutural destas duas substâncias. Enquanto a metionina é o principal doador de grupos metila no organismo animal, através da AdoMet, a S-metil-cisteina é metabolizada por uma via distinta, dando origem ao metanotiol e dissulfetos, cujos efeitos no homem estão sendo estudados. A leguminosa Vigna mungo (L.) Hepper, largamente cultivada e consumida pela população asiática, possui o dipeptídeo $\gamma$-glutamil-L-metionina, que ao contrário da S-metil-L-cisteína encontrada no Phaseolus vulgaris L., poderá representar uma fonte adicional de metionina para ser utilizada nutricionalmente pelos mamíferos, sem os inconvenientes inerentes à S-metil-L-cisteina 


\section{Summary}

Organosulfur compounds represented by sulfur $\gamma$-glutamyl peptides and their free amino acids are widely distributed in vegetables belonging to the Alliaceae, Cruciferae and Leguminosae families. The metabolism of these sulfur compounds through enzymatic systems gives rise to characteristic flavor compounds and secondary metabolites which are responsible for some biological activities when these vegetables are ingested by mammals. The physiological responses differ between the three vegetable families considered, due to generation of different patterns of metabolites, reflecting the presence or the absence of specific enzymes involved in their biosynthesis. In Alliaceae, some of these metabolites are sulfur compounds produced by the enzymatic action upon disruption of the plant tissue. Besides being flavor precursors, these substances are well known due to their potential benefits on human healthy. The metabolic pathway of the sulfur peptides from Cruciferae gives raise mainly of S-methyl-L-cysteine sulfoxide which can be converted to the highly toxic methanethiol and some dissulfides. Ruminants are the most sensitive mammmals, developing symptoms of haemolytic anaemia. In legumes, between all genera studied, the $\gamma$-glutamyl-S-methyl-L-cysteine and the free Smethyl-L-cysteine can be found in high levels in Phaseolus vulgaris L. seeds. The sum of both substances may represent until $50 \%$ of the methionone content present in these beans expressed as molar basis, and would disappear only during sprouting. The peptide is stable during cooking but it undergoes hydrolysis when beans are ingested appearing in peripheral blood as free S-methyl-L-cysteine only. The metabolic pathways of methionine and S-methyl-1-cysteine are quite different, despite their molecular similarities. While methionine produces AdoMet, known as the main methyl groups donator, the S-methyl-L-cysteine gives origin of methanethiol and sorne kinds of dissulfides, whose effects on humans are still studied. The legume Vigna mungo (L.) Hepper is widely grown and consumed in southern Asiatic countries providing a significant portion of dietary protein. The presence of large amounts of $\gamma$-glutamyl-Lmethionine characterizes these seeds which might act as an additional source of methionine for nutritional purposes. 


\section{Referências Bibliográficas}

AL MARDIN, H., LEONARD, J., BARTLETT, K, LLOYD, S., RECORD, C.O. Effect of methionine loading and endogenous hypermethioninaemia on blood mercaptans in man. Clin. Chim. Acta, Amsterdam, v. 176, p. 83-90, 1988.

ALPERS, D.H. Uptake and fate of absorbed amino acids and peptides in the mammalian intestine. Fed. Proc., Washington, v. 45, p.2261-2267, 1986.

ANDERSON, J.W. Assimilation of inorganic sulfate into cysteine. In: Conn, E.E., Stumpf, P.K, eds. The biochemistry of plants. New York: Academic Press, 1980/1990. v.5, p.203

ANKRI, S., MIRELMAN, D. Antimicrobial properties of allicin from garlic. Microbes Infect, Paris, v.1, n.2, p.125-129, 1999

ASSOCIATION OF OFFICIAL ANALYTICAL CHEMISTS. Official methods of analysis. 15.ed. Washington: AOAC, 1990.

AQUEL, M.B., GHARAIBAH, M.N., SALHAB, A.S. Direct relaxant effects of garlic juice on smooth and cardiac muscle. J. Ethnopharmacol., Amsterdam, v.33, p.13-19, 1991.

ALLAKH, M.S., PASRICHA, N.S. Interactions effect of sulphur and phosphorus on growth and nutrient content of mung bean (Phaseolus aureus L.). Plant Soil, Dordrecht, v.47, p.341-350, 1977.

De acordo com a NBR6023/90 preconizada pela ASSOCIAÇĀO BRASILEIRA DE NORMAS TÉCNICAS (ABNT). As abrevialuras dos litulos dos periódicos segucm o CHEMICAL ABSTRACT SER VICE SOURCE INDEX (CASSI) 1999 [CD-Rom] 
BARROS, R.M.C. Distríbuição e quantificação de $\gamma$-glutamil-S-metilcisteína em leguminosas comestíveis: relação com a taxonomia. São Paulo, 1998. 120p. (Dissertação de Mestrado - Faculdade de Ciências Farmacêuticas - USP).

BARROS, R.M.C., LANFER MARQUEZ, U.M. Teor e distribuição de y-glutamil-Smetil-cisteina em leguminosas. In: REUNIÃO NACIONAL DE PESQUISA DE FEIJÃO, 5, Goiânia, 1996. Anais. Goiania: EMBRAPA, 1996. p. 501-503.

BARROS, R.M.C., LANFER MARQUEZ, U.M. Distribuição de gama-glutamil peptídeos em sementes de leguminosas comestiveis. CONGRESSO BRASLEIRO DE CIÊNCIA E TECNOLOGIA DE ALIMENTOS, 16, Rio de Janeiro, 1998 Anais. [CD-ROM]. Rio de Janeiro: CBCTA, 1998

BARROS, RMC., MAJUMOER, I., FONSECA JUNIOR, N.S., LANFER MARQUEZ, U.M. Gamma-glutamil peptideos sulfurados em sementes de leguminosas comestiveis. In: REUNIÃO NACIONAL DE PESQUISA DE FEIJÃO, 6, Salvador, 1999. Anais. Goiânia: EMBRAPA, 1999. v. 1, p.877-880

BELL, E.A. Comparative biochemistry of non-protein amino acids. In: HARBORNE, J.B., BOULTER, D., TURNER, B.L. Chemotaxonomy of the Leguminosae. London: Academic Press, 1971. p.179-206.

BENEVENGA, N.J. Toxicities of methionine and other amino acids. J. Agric. Food Chem., Columbus, v.22, p.2-9, 1974

BENEVENGA, N.J., STEELE, R.D. Adverse effect of excessive consumption of amino acids. Annu. Rev. Nutr., Palo Alto, v.4, p.157-181, 1984.

BENEVENGA, N.J., YEH, M.H., LALICH, J.J. Growth depression and tissue reaction to the consumption of excess dietary methionine and S-methyl-L-cysteine . Nutr. Bethesda, v. 106, p.1714-1720, 1976. 
BIRCH, A.N.E., FELlOWS, L.E., EVANS, S.V., DOHERTY, K Paraaminophenylalanine in Vigna: possible taxonomic and ecological significance as a seed defence against bruchiós. Phytochemistry, Amsterdam, v. 25 , p.2745-2749, 1986.

BLOCK, E. The organosulfur chemistry of the genus Allium: implications for the organic chemistry of sulfur. Angew. Chem. Int. Ed. Engl, Weinheim, v.31, p.1135-1178, 1992.

BLOM, H.J., TANGERMAN, A. Methanethiol metabolism in whole blood. J. Lab. Clin. Med, St. Louis, v. 111, p.606-610, 1988.

BLOM, H.J., CHAMULEAU, R.A.F.M., ROTHUIZN, J., DEUTZ, N.E.P., TANGERMAN, A. Methanethiol metabolism and its role in the pathogenenesis of hepatic encephalopathy in rats and dogs. Hepatology, Orlando, v.11, p.682-689, 1990

BLOM H.J., FERENCI, P., GRMMM, YAP, H.S, TANGERMAN, A. The role of methanethiol in the pathogenesis of hepatic encephalopathy. Hepatology. Orlando, v. 13, p.445-454, 1991.

BLOM, H.J., BOERS, G.H.J, ELZEN, J.P.A., GAHL, W.A., TANGERMAN, A. Transamination of methionine in humans. Clin. Sci., Colchester, v. 76, p.43-49, 1989.

BRAVO, L., SIDDHURAJU, P., SAURA-CALIXTO, F. Composition of underexploited Indian pulses: comparison with common legumes. Food Chem., Amsterdam, v.64, p.185-192, 1999. 
CANNIATTI-BRAZACA, S.G., MANCINI-FILHO, J., LAM-SÁNCHEZ, A. Melhoramento genético na qualidade nutricional de alimentos vegetais. II. Leguminosas: controle genético de fatores antinutricionais e de carotenóides. Cad. Nutr, Ribeirão Preto, v.6, p.44-61, 1993.

CANNIATTI-BRAZACA, S.G., NOVAES, N.J, SALGADO, J.M., MARQUEZ, U.M.L., MANCINI FLLHO, J. Avaliação nutricional do feijão Guandu (Cajamus cajan L.). Ciênc. Tecnol. Aliment., Campinas, v. 16, p. 36-41, 1996.

CASE, G.L., BENEVENGA, N.J. Evidence for a S-adenosylmethionine independent catabolism of methionine in the rat. J. Nutr., Bethesda, v.106, p.1721-1736, 1976.

CECI, L.N., CURZIO, O.A., PONILIO, A.B. Effects of radiation and storage on the $\gamma$ glutamyl transpeptidase activity of garlic bulbs cv "Red". J. Sci. Food Agric, Sussex, v. 59, p.505-510, 1992.

CHALLENGER, L., WALSHE, J.M. Methyl mercaptan in relation to fetor hepaticus Biochem. J., Colchester, v.59, p.372-375, 1955.

CHIN, H.W., LINDSAY, R.C. Mechanisms of formation of volatile compounds following the action of cysteine sulfoxide lyases. I Agric Food Chem., Columbus, v.42, p. $1529-1536,1994$

CHITRA, U., SINGH, U., VENKATESWARA, R. Phytic acid, in vitro protein digestibility, dietary fiber, and minerals of pulses as infuenced by processing methods. Plant Foods Hum. Nutr., Dordrecht, v.49, p.307-316, 1996

CURTHOYS, N.P., HUGHEY, R.P. Characterization and physiological function of rat renal gamma-glutamyltranspeptidase. Enzyme, Basel, v.24, p.383-403, 1979 
DARDENNE, G.A, THONART, P. $\gamma$-glutamylphenylalanine in Dolichos seeds. Phytochemistry, Amsterdam, v. 12, 0.473, 1973.

DAS, M., RADHAKRISHNAN, A.N. Role of peptidase and peptide transport in intestinal absorption of proteins. World Rev. Nutr. Diet., Basel, v.24., p.58-87, 1976.

D'MELLO, J.P.F. Toxic amino acids. In: D'MELLO, J.P.F., DUFFUS, C.M., DUFFUS, H. Toxic substances in crop plants. Cambridge: Royal Society of Chemistry, 1992. p. $22-48$.

DERBALI, E., MAKHLOUF, J., VEZINA, L.-P. - Biosyntheis of sulfur volatile compounds in broccoli seedlings stored under anaerobic conditions. Postharv. Biol. Technol., Oxford, v.13, 191-204, 1998

DI PENTMMA, J.H., RÍOS, J.J., CLEMENTE, A., OLÍAS, J.M. Biogenesis of off-odor in broccoli storage under low-oxygen atmosphere. J. Agric. Food Chem, Columbus, v.43, p. $1310-1313,1995$.

DUBOIS, M., GLLLES, K., A., HAMMTON, J.K., REBERS, D.A., SMITH, F. Colorimetric methods of determination of sugars and related substances. Anal. Chem., Columbus, v. 28, p. 350-356, 1956.

DUNCAN, A., ELLINGER, T.M., GLENNEE, R.T. Determination of methionine by gasliquid chromatography: modifications in its application to legumes and cereals. J. Sci. Food Agric, Sussex, v.35, p.381-384, 1984.

ELLINGER, G.M., DUNCAN, A. The determination of methionine in proteins by gasliquid chromatography. Biochem. J., Colchester, v 155, p.615-621, 1976

EVANS, R.J., BANDEMER, S.L. Nutritive value of legume seed proteins. J. Agric Food Chem., Columbus, v. 15, p.439-443, 1967 
EVANS, M., BOULTER, D. S-methyl-L-cysteine content of various legume meals. Qual. Plant.-Plant Foods Hum Nutr., The Hague, v.24, p.257-261, 1975.

EYRE, M.D., PHILLIPS, D.E., EVANS, I.M., THOMPSON, A. The nutritional role of S-methyl-L-cysteine. I. Agric. Food Chem., Columbus, v.34, p.696-700, 1983.

FAO/WHO. Protein Quality Evaluation. Report of a Joint FAO/WHO expert consultation. Food and Nutrition Paper 51; FAO, Rome, 1991

FENWICK, G.R., HANlEY, A.B. The genus Allium, Part 2. CRC Crit. Rev. Food Sci. Nutr, Fort Lauderdade, v.22, p.273-377, 1985.

FINKELSTEIN, A., BENEVENGA, N.J. Developmental changes in the metabolism of 3methylthiopropionate in the rat. J. Nutr., Bethesda, v.114, p.1622-1629, 1984.

FINKELSTEIN, A., BENEVENGA, N.J. The effect of methanethiol and methionine toxicity on the activieties of cytochrome $c$ oxidase and enzymes envolved in protection from peroxidative damage. J. Nutr., Bethesda, v.116, p.204-2I 5, 1986.

FOWDEN, L, PEA, P.J. Mechanism of plant avoidance ao autotoxicity by secondary metabolites, especially by nonprotein amino acids. In: ROSENTHAL, G.A, JANZEN, D.H., eds. Herbivores: their interaction with secondary plant metabolites. New York: Academic Press, 1979. p. 135-160.

FRIEDMAN, M. GUMBMANN, M.R. The utilization and safety of isomeric sulfurcontaing amino acids in mice. J. Nutr., Bethesda, v.114, p.2301-2310, 1984.

FRIEDMAN, M. Improvement in the safety of foods by SH-containing amino acids and peptides: a review. J. Agric. Food Chem., Columbus, v.42, p.3-20, 1994 
GAHL, W.A., FINKELSTEIN, J.D., MULLEN, K.D., BERNARDINI, I. MARTIN, J.J. BACKLUND, P., ISHAC, K.G., HOOFNAGLE, J.H., MUDD, S.H. Hepatic methionine adenosyltransferase deficiency in a 31 -year-old man. Am. J. Hum. Genet., Chicago, v.40, p.39-47, 1987.

GAHL, W.A., BERNARDINI, I, FINKELSTEIN, J.D., TANGERMAN, A., MARTIN, J.J, BLOM, H.J., MULLEN, K.D., MUDD, S.H. Transsulfuration in an adult with hepatic methionine adenosyltransferase deficiency. J. Clin. Invest., Ann Arbor, v.81, p.390-397, 1988.

GANAPATHY, V., BRANDSCH, M., LEIBACH, F.H. Intestinal transport of amino acids and peptides. In: JOHNSON, R.L, ed. Physiology of the gastrointestinal tract. New York: Raven Press, 1994. p.1773-1794.

GARDNER, M.L.G., LINDBLAD, B.S., BURSTON, D., MATTHEWS, D.M. Transmucosal passage of intact peptides in the guinea pig small intestine in vivo: a re-appraisal. Clin. Sci., Colchester., v.64, p.433-439, 1983.

GARVEY, T.Q., HYMAN, P.E., ISSELBACHER, J.J. $\gamma$-Glutamyltranspeptidase of rat intestine: localization and possible role in amino acid transport Gastroenterology. Orlando, v.71, p.778-785, 1976.

GAULL, G.E., TALLAN, H.H., LONSDALE, D., PRZYREMBEL, H., BASSEWITZ, D.B. von Hypermethioninemia associated with methionine adenosyltransferase deficiency: clinical, morphologic and biochemical observations on four patients. J. Pediatrics, St. Louis, v.98, p.734-741, 1981.

GIOVANELLI, J., MUDD, S.H, DATKO, A.H. Sulfur amino acids in plants. In: CONN, E.E., STUMPF, P.K., eds. The biochemistry of plants. New York: Academic Press, 1980/1990., v 5, p.203 
GOONERATNE, J., MAJSAK-NEWMAN, G., ROBERTSON, J.A., SELVENDRAN, R.R. Investigation of factors that affect the solubility of dietary fiber, as nonstarch polysaccharides, in seed tissues of mung bean (Vigna radiata) and black gram (Vigna mungo). J. Agric. Food Chem., Columbus, v 42, n.3, p.605-610, 1994.

GREENHALGH, J.F.D. Kale anaemia. Proc. Nutr. Soc., Wallingford, v.28, p. 128-131, 1969.

GRIFFITH, O.W. Mammalian sulfur amino acid metabolism: an overwiev. Methods Enzymol., San Diego, v.143, p.367-371, 1987

GRIFFITHS, W.S., McFARLANE-SMITH, W.H., BOAG, B. The effect of cultivar, sample date and grazing on the concentration of S-methylcysteine sulphoxide in oilseed and forage rapes (Brassica napus). J. Sci. Food Agric., Sussex, v. 64, p. 283$288,1994$.

HALL, D., SMITH, I.K. Partial purification and characterization of cystine lyase from cabbage (Brassica oleracea, var. capitata). Plant Physiol, Rockville, v.72, p.654-658, 1983.

HAMAMOTO, A., MAZELIS, M. The C-S-lyases of higher plants. Isolation and properties of homogeneous cystine lyase from broccoli (Brassica oleraeae var botrytis) buds. Plant Physiol., Rockville, v.80, p.702-706, 1986

HANUM, T., SINHA, N.K., GUYER, D.E., CASH, J.N. Pyruvate and flavor development in macerated onions (Allitum cepa L.) by $\gamma$-glutamyl transpeptidase and exogenous C-S lyase. Food Chem, Amsterdam, v.54, p. 183-188, 1995.

HENDRICH, S., PITOT, H.C. Enzymes of glutatione metabolism as biochemical markers during hepatocarcinogenesis. Cancer Metastasis Rev., Dordrecht, v.6, p.155178,1987 
HUGHEY, R.P., CURTHOYS, N.P. Comparison of size and physical properties of a $\gamma$ glutamyltranspeptidase purified from rat kidney following solubilization with papain or Triton X-100. J. Biol. Chem., Bethesda, v.251, p.7863-7870, 1976.

INSTITUTO ADOLFO LUTZ. Normas analíticas do Instituto Adolfo Lutz. 3.ed. São Paulo: s.n., 1985, v.1,371p.

INSTYTUTO AGRONÔMICO DO PARANÁ. Cartas climáticas do Estado do Paraná. Londrina: IAPAR, 1994. 49p.

KASAI, T., LARSEN, P.O. Chemistry and biochemistry of $\gamma$-glutamyl derivatives from plants including mushrooms (Basidiomycetes). Prog. Chem. Org. Nat. Prod., Wein, v. 39, p. $173-285,1980$

KASAI, Y., OHMYIA, A., SAKAMURA, S. $\gamma$-glutamyl transpeptidases in the metabolism of $\gamma$-glutamyl peptides in plants. Phytochemistry, Amsterdam, v.21, p. 1233-1229, 1982.

KASAI, T, SAKAMURA, S., SAKAMOTO, R. Isolation and identification of $\gamma$ glutamyl-y-glutamylmethioninesulfoxide from green gram seed. Agric. Biol. Chem., Tokyo, v.36, p.967-969, 1972a.

KASAI, T., SAKAMURA, S., INAGAKI, S., SAKAMOTO, R. Isolation and identification of $\gamma$-glutamyl- $\gamma$-glutamylmethionine from green gram seed. Agric. Biol. Chem., Tokyo, v. 36, p.2621-2623, 1972 b.

KASAI, T., SANO, M., SAKAMURA, S. Amino acid composition of broad bean (Vicia $f a b a)$. I. Pattern of acidic amino acid fraction. Nippon Nogei Kagaku Kaishi, Tokyo, v.49, p.313-459, 1975. 
KASAI, T., SHIROSHITA, Y., SAKAMURA, S. $\gamma$-glutamyl peptides of Vigna radiala seeds. Phytochemistry, Amsterdam, v.25, p.679-682, 1986

KAUR, D., KAPOOR, A.C. Some antinutritional factors in rice bean (Vigna umbellata) effecrs of domestic processing and cooking methods. Food Chem., Amsterdam, v.37, p. $171-179,1990$

KAUR, D, KAPOOR, A.C. Nutrient composition and antinutritional factors of rice bean (Vigna umbellata). Food Chem., Amsterdam, v.43, p. 119-124, 1992

KOHNHORST, A.L., SMITH, D.M., UEBERSAX, M.A , BENNINK, M.R. Compositional, nutritional and functional properties of meals, flours and concentrates from navy and kidney beans (Phaseolus vulgaris, L.) J. Food Quality, Trumbull, v. 13, p. $435-446,1987$.

KÖHLER, H.H., BURKE, D.W. Nutrient and sensory properties of dry beans (Phaseolus vulgaris L.) grown under various cultural conditions. J. Food Sci., Chicago, v.53, p. $1135-1138,1988$

KRANZ, W.M. População de plantas. In: O Feijão no Paraná. Londrina: Fundação Instituto Agronômico do Paraná, 1989, p.115-125.

KRAUSS, F, SCHMODT, A. Sulphur sources for growth of Chlorella fusca and their influence on key enzymes of sulphur metabolism. J. Gen. Microbiol., Colchester, v.133, p. 1209-1219, 1987

KREST, I., KEUSGEN, M. Stabilization and pharmaceutical use of alliinase Pharmazie, Eschborn, v.54, n.4, p 289-293, 1999. 
KRISTENSEN, I., LARSEN, P.O., SORENSEN, H. Free amino acids and $\gamma$-glutamyi peptides in seeds of Fagus silvatica. Phytochemistry, Amsterdam, v. 13 p.2803-2811, 1974.

KRUMDIEK, C.L. Folic acid. In: BROWN, M.L., ed. Present knowledge in nutrition. 6.ed. Washington: International Life Sciences Institute, Nutrition Foundation, 1990. p. $179-188$.

KUBEK, T., DRHOVÁ, V., VELISEK, J. Thermal degradation of S-methylcysteine and its sulfoxide-Important flavor precursors of Brassica and Allium vegetables. J. Agric. Food Chem., Columbus, v.46, p. 4334-4340.

KUMARI, K., AUGUSTI, K.T. Antidiabetic effects of S-methylcysteine sulphoxide on alloxan diabetes. Planta Med., Stuttgard, v.61, p.72-74, 1995.

KRISTENSEN, I., LARSEN, P.O., SORENSEN, H. Free amino acids and $y$-glutamyl peptides in seeds of Fagus silvatica. Phytochemistry, Amsterdam, v.13, p.2803-281 1, 1974.

KYUNG, K. H, FLEMING, H.P. S-methyl-L-cysteine sulfoxide as the precursor of methyl methanethiolsulfinate, the principal antibacterial compound in cabbage. $\mathrm{J}$. Food Sci., Chicago, v.59, p.350-355, 1994.

LABANAUSKAS, C.K, STOLZY, L.H., HANDY, M.F. Protein and free amino acids in wheat grain as affected by soil types and salinity levels in irrigation water. Plant Soil, Dordrecht, v.59, p.299-316, 1981.

LAM-SANCHEZ, A. Melhoramento de leguminosas visando a qualidade nutricional. In: SALGADO, J. M., coord. Interface, nutrição x agricultura. Piracicaba: Degaspari, 1989. p. 57-82 
LANCASTER, J.E, KELLY, K.E. Quantitative analysis of the S-alk(en)yl-L-cysteine sulphoxides in onion (Allizum cepa L.) J. Sci. Food Agtic., Sussex, v.34, p. 1229-1235, 1983

LANCASTER, J.E., SHAW, M.L. $\gamma$-glutamyl peptides in the biosynthesis of S-alk(en)ylL-cysteine sulphoxides (flavour precursors) in allium. Phytochemistry, Amsterdam, v. 28, n. 2, p. $455-460,1989$.

LANCASTER, J.E., SHAW, M.L. Metabolism of $y$-glutamyl peptides during development, storage and sprouting of onion bulbs. Phytochemistry, Amsterdam, v.30, n.9, p.2857-2859, 1991.

LANCASTER, J.E., REYNOLDS, H. S., SHAW, M.L., DOMMSSE, E.M., MUNRO, J Intra-cellular localization of the biosynthetic pathway to flavour precursors in onion Phytochemistry, Amsterdam, v.28, n.1, p.461-464, 1989.

LANFER MARQUEZ, U.M, BARROS, R.M.C., LAJOLO, F.M. Chemically determined total and available methionine in beans (Phaseolus vulgaris L.) and isolated protein fractions. Food Chem., Amsterdam, v.55, p. 179-184, 1996

LARSEN, P.O. Physical and chemical properties of amino acids. In: STUMPF, P.K., CONN, E.E., eds. The biochemistry of plants: a comprehensive treatise. New York: Academic Press, 1980, v.5, p.225-269, 1980.

LAWN, R.J., AHN, C.S. Mung bean (Vigna radiata (L.) Wilczek/Vigna mungo (L.) Hepper). In: SUMMERFIELD, R.J., ROBERTS, E.H. Grain Legume Crops. London: Collins, 1985. p. 584-623.

LI, C.-J., BROWNSON, D.N., MABRY, T.J., PERERA, C., BELL, A. Nonprotein amino acids from seeds of Cycas circinalis and Phaseolus vulgaris. Phytochemistry, Amsterdam, v.42, n.2, p.443-445, 1996. 
LIVESEY, G. Methionine degradation: anabolic and catabolic. Trends Biochem Sci., Amsterdam., v.9, p.27-29, 1984

McINTOSH, A. ELLINGER, G.M. Determination of methionine in the seeds of legumes. Proc. Nutr. Soc., Wallingford, v.35, p.148A, 1976.

MAHAJAN, R., MALHORTRA, S.P., SINGH, R. Characterization of seed storage proteins of urdbean (Vigna mungo). Plant Foods Hum. Nutr. Dordrecht, v.38, p. 163 $173,1988$.

MARLETTA, L., CARBONARO, M., CARNOVALE, E. In-vitro protein and sulphur amino acid availability as a measure of bean protein quality. J. Sci. Food Agric., Sussex, v.59, p.497-504, 1992.

MARKS, H.S., HILSON, J.A., LEICHTWEIS, H.C., STOEWSAND, G.S. Smethylcysteine sulfoxide in Brassica vegetables and formation of methylmethanethiosulfinate from Brussels sprout. J. Agric Food Chem., Columbus, v. 40, p. $2098-2101,1992$.

MATHEWS, D. M., PAYNE, J.W. Transmembrane transport of small peptides. CurT. Top. Membr. Transp., New York, v. 14, p.331-425, 1980.

MAW, G.A. Biochemistry of S-methyl-L-cysteine and its principal derivatives. Sulfur Rep., Amsterdam, v.2, p. 1-32, 1982.

MEISTER, A. On the enzymology of amino acid transport Cancer Res., Philadelphia, v.54, p.1969S-1975S, 1994.

MLNER, J.A. Garlic: its anticarcinogenic and antitumorigenic properties. Nutr. Rev., Secaucus, v.54, n.11(pt.2), p.S82-S86, 1996. 
MIRELMAN, D. Antimicrobial properties of allicin from garlic. Microbes Infect., Paris, v. 1, n. 2, p. $125-129,1999$.

MITCHELL, A.D., BENEVENGA, N.J. The role of transamination in methionine oxidation in the rat. J Nutr, Bethesda, v. 108, p.67-78, 1978.

MONTI, L.M., GRILLO, S. Legume seed improvement for protein content and quality. Qual. Plant. Plant.- Foods Hum. Nutr., The Hague, v.32, p.253-266, 1983.

MOORE, S. On the determination of cystine as cysteic acid. J. Biol. Chem., Bethesda, v.238, p. $235-237,1963$

MORRIS, C.J., THOMPSON, J.F. The detection, isolation and identification of $\gamma$ glutamyl-S-methylcysteine from beans. Arch. Biochem. Biophys., Orlando, v.73, p.281-283, 1958

MORRIS, C.J., THOMPSON, J.F. The isolation and characterization of $y$-L-glutamyl-Ltyrosine and $\gamma$-L-glutamyl-L-phenylalanine from soybeans. Biochemistry, Washington, v.4, p.706-709, 1962.

MÜTSCH-ECKNER, M., MEIER, B., WRIGHT, A.D., STICHER, O. $\gamma$-glutamyl peptides from Allium sativum bulbs. Phytochemistry, Amsterdam, v.31, p.2389-2391, 1992.

NOMURA, J., NISHIZUKA, Y., HAYASHI, O. S-alkylcysteinase: enzymatic cleavage of S-methylcysteine and its sulfoxide. J. Biol Chem., Bethesda, v.238, p. 1441-1446, 1963. 
OI, Y., KAWADA, T., SHISHIDO, C., WADA, K., KOMINATO, Y., NISHIMURA, S., ARIGA, T., IWAI, K. Allyl-containing sulfides in garlic increase uncoupling protein content in brown adipose tissue, and noradrenaline and adrenaline secretion in rats. $\underline{I}$ Nutr., Bethesda, v. 129, p.336-342, 1999.

OTOUL, E, MARECHAL, R., DARDENNE, G., DESMEDT, F. Des dipeptides soufres differencient nettement Vigna radiata de Vigna mungo. Phytochemistry, Amsterdam, v. 14, p.173-179, 1975.

PADOVESE, R. Importância biológica da $\gamma$-glutamil-S-metilcisteina do feijão (Phaseolus vulgaris L.). São Paulo, 1997. 86p. (Dissertação de Mestrado - Faculdade de Ciências Farmacêuticas - USP).

PADOVESE, R, LANFER MARQUEZ, U.M. Importância biológica da gama-glutamilS-metil-cisteína do feijão (Phaseolus vulgaris L.) In: CONGRESSO BRASLEIRO DE CIÊNCIA E TECNOLOGIA DE ALIMENTOS, 16, Rio de Janeiro, 1998. Anais. Rio de Janeiro: SBCTA, 1998.

PADOVESE, R., KINA, S.M., BARROS, R.M.C., BORELLI, P., LANFER MARQUEZ, U.M. Biological importance of $\gamma$-glutamyl-S-methylcysteine of kidney bean (Phaseolus vulgaris L.) Food Chem., Amsterdam. [Aceito para publicação].

PARRA, M.S. Nutrição e adubacão. In: O Feijão no Paraná. Londrina: Instituto Agronômico do Paraná, 1989. p.79-100.

PARTRIDGE, S.M., WESTALL, R.G. Displacement chromatography on synthetic ionexchange resins. Biochem. J., Colchester, v.44, p.418-428, 1949.

PEACE, R.W., KEITH, M.O., SARWAR, G., BOTTING, H.G. Effects of storage on protein nutritional quality of grain legumes. J. Food Sci., Chicago, v.53, p.439-44l, 1988. 
PLANTS and their constituents In: BISBY, F.A., BUCKINGHAM, J., HARBORNE, J.B Phytochemical dictionary of the Leguminosae. London: Chapman and Hall, 1994. v. $1,1051 p$.

PROSKY, L., SCHWELER, T.F., ASP, N.S., DEVRIES, J.W., FURDA, I. Determination of insoluble, soluble and total dietary fibre in food products. Inter laboratory study. J. Assoc. Off. Anal. Chem., Washington, v.71, p.1017$1023,1998$.

RAGHUVANSHI, R.S., SHARMA, S., SUKLA, P. Proximate Composition of black gram varieties (Vigna mungo L. Hepper). J. Dairying, Foods Home Sci, v.12, n.4, p. 182-184, 1993.

RAGHUVANSHI, R.S., SHARMA, S., SINGH, P. Impact of physical and nutritional characteristics on cookability of black gram genotypes. J. Dairying, Foods Home Sci, v. 16, n.2, p. 140-142, 1997.

RAYAS-DUARTE, P., SATTERLEE, L.O., ROMERO, A.L. Enzymatic release of peptides, methionine and cystine from dry beans following various heat treatments. Food Sci., Chicago, v.53, p.468-472, 1988

REESE, C.J. Interaction of allelochemicals with nutrients in herbivore food: In: ROSENTHAL, G.A, JANZEN, D.H, eds. Herbivores: their interaction with secondary plant metabolites. New York: Academic Press, 1979.

REIS GIADA, M.L. Isolamento, caracterização e quantificação de peptídeos $\gamma$-glutamil sulfurados no feijão (Phaseolus vulgaris L.). São Paulo, 1995. (Dissertação de Mestrado - Faculdade de Ciências Farmacêuticas - USP). 
REIS GIADA, M.L., MIRANDA, M.T.M., LANFER MARQUEZ, U.M. Sulphur $\gamma$ glutamyl peptides in mature seeds of common beans (Phaseolus vulgaris L.). Food Chem., Amsterdam, v.61, p.177-184, 1998.

RINDERKNECHT, H.D., THOMAS, D., ASLIN, S. $\gamma$-glutamyl-S-methyl-cystein und andere peptide in der Mondbohne (Phaseolus lunatus L.). Helv. Chim. Acta, Zurich, v.41, p.1-11, 1958 .

RODRIGUEZ, M.S., MENDOZA, E.M.T. Nutritional assessment of seed proteins in rice bean [Vigna Umbellata (Thumb.) Ohwi and Ohashi]. Plant Foods Hum. Nutr., Dordrecht, v.41, p. 1-9, 1991.

ROSENTHAL, G.A., BELL, E.A. Naturally occurring, toxic nonprotein amino acids. In: ROSENTHAL, G.A, JANZEN, D.H, eds. Herbivores: their interaction with secondary plant metabolites. New York: Academic Press, 1979. p.353-385.

SGARBIERI, V.C. Estudo do conteúdo e de algumas características das proteínas em sementes de planta da familia Leguminosae. Ciênc. Cult., São Paulo, v.32, p.78-84, 1980.

SGARBIERI, V.C., GALEAZZI, MA.M. Quantification and some chemical and biochemical chracterization of nitrogenous substances from varieties of common beans (Phaseolus vulgaris, L.) J. Food Biochem., Trumbull, v. 14, p.233-247, 1990.

SHAW, M.L., LANCASTER, J.E., LANE, G.A. Quantitative analysis of the major $\gamma$ glutamyl peptides in onion bulbs (Allium cepa). J. Sci. Food Agric., Sussex, v.48, p.459-467, 1989.

SHEELA, C.G., KUMUD, K., AUGUSTI, K.T. Anti-diabetic effects of onion and garlic sulfoxide amino acids in rats. Planta Med., Stuttgard, v.61, p.356-357, 1995. 
SHEPARD, M., LAWN, R.J., SCHNEIDER, M. lnsects on grain legumes in northern Australia: a survey of potential pests and their enemies. St. Lucia: University of Queensland Press, 1983 Apud: SUMMERFIELD, R.J., ROBERTS, E.H., eds. Grain legume crops. London: Collins, 1985, pt.II, cap.13, p. 584-623.

SIDRA - Sistema de recuperação de informações do Instituto Brasileiro de Geografia e Estatística. Apud: IBGE [Online]. Available: http://www sidra ibge gov.br

SIEGERS, C.P., STEFFEN, B., ROBKE, A., PENTZ, R. The effects of garlic preparations against tumor cell proliferation. Phvtomedicine Jena, v.6, n.1, p.7-11, 1999.

SCISLOWSKI, P.W., PICKARD, K. The regulation of transaminative flux of methionine in rat liver mithocondria. Arch. Biochem. Biophys., Orlando, v.314, p 412-416, 1994.

STIPANUK, M.H. Metabolism of sulfur-containing amino acid. Annu. Rev. Nutr, Palo Alto, v.6, p. 179-209, 1986.

SUNDARAM, S.G., MONER, J.A. Diallyl disulfide inhibits the proliferation of human tumor cells in culture. Biochim. Biophys. Acta, Amsterdam, v.1315, r. 1, p. 15-20, 1996.

TANAKA, R.T., MASCARENHAS, H.A.A. Teores e produtividade de óleo e de proteina de soja devidos à aplicação de calcáreo e gesso agrícola. In: CONGRESSO LATINO AMERICANO SOBRE PROCESSAMENTO DE ÓlEOS E GORDURAS, 6, Campinas, 1995. Anais. Campinas: Sociedade Brasileira de Óleos e Gorduras, 1995.

TANAKA, R.T., MASCARENHAS, H.A.A. MIRANDA, M.A.C. Efeito da calagem sobre o teor e a produção de proteína e óleo de soja. Agronômico, Campinas, v 42, n. 3, p. 181-185, 1990 . 
TANAKA, R.T., MASCARENHAS, H.A.A. REGITANO D'ARCE, M.A.B., GALLO, P.B. Concentração e produtividade de óleo e proteína de soja em função da adubação potássica e calagem. Pesqu. Agropecu. Bras, Brasília, v.30, n.4, p.463-469, 1995.

THOMPSON, J.F., MORRIS, C.J., ZACHARIUS, R.M. Isolation of (-) S-methyl-Lcysteine from beans (Phaseohs vulgaris). Nature, London, v. 178, p.593, 1956.

THOMPSON, J.F., MORRIS, C.J., GERING, R.K. Purification of plant amino acids on paper chromatography. Anal. Chem., Columbus, v.31, p.1028-1031, 1959.

THOMPSON, J.F., TURNER, D.H., GERING, R.K. $\gamma$-Glutamyl transpeptidase in plants. Phytochemistry, Amsterdam, v.3, p.33-46, 1964.

TONNIES, G., KOLB, J.J. Techniques and reagents for paper chromatography. Anal Chem., Columbus, v.23, p.823-826, 1951.

VERDCOURT, B. Studies in the Leguminosae - Papilionodeae for the flora tropical east Africa. Kew Bull., London, v.24, p.507-569,. Apud: SAVAGE, G.P., DEO, S. The nutritional value of mung bean and urd (Vigna radiata var. aureus and var. mungo). Nutr Abstr. Rev., Slough, v.59, p.639-662, 1989.

VIGNA CROP GERMPLASM COMMITTEE. Vigna germplasm curtent status and future needs. [Online]. Available: http://www.arsgrin.gov/nggs/cgc reports/vigna96.html

VINCENZINI, M.T., FAVILLI, F, IANTOMASl, T. Intestinal uptake and transmembrane transport systems of intact GSH: characteristics and possible biological roles. Biochem. Biophys. Acta., Amsterdam, v. 11 13, p.13-23, 1992. 
WALLSGROVE, R.M., DOUGHTY, K.J., BENNET, R.N. Apud: SINGH, B.J., ed. Plant amino acids: biochemistry biotechnology. New York: Marcel Dekker, 1999. p.523561

WALEY, S.G. Naturally ocurting peptides. Adv. Protein Chem., San Diego, v.21, p.1451,1966

WHO monographs on selected medicinal plants. Geneva: World Health Organization, v. $1,1999$.

WU, Y.V., WALL, J.S. Lysine content of protein increased by germination of normal and high L-lysine sorghum. J Agric. Food Chem., Washington, v.28, p.455-458, 1980.

ZACHARIUS, R.M. Composition of the nitrogenous components of the bush bean seed (Phaseolus vulgaris) including isolation of $\delta$-acetylornithine. Phytochemistry, Amsterdam, v.9, p.2047-2051, 1970.

ZACHARIUS, R.M., MORRIS, CJ., THOMPSON, J.F. The detection, isolation and identification of $\gamma$-glutamylethyl-L-cysteine Arch. Biochem. Biophys, Orlando, v.73, p.281-.283, 1958.

ZACHARIUS, R.M, MORRIS, C.J., THOMPSON, J.F. The isolation and characterization of $\gamma$-L-glutamyl-S-methyl-L-cysteine from Kidney beans (Phaseolus vulgaris). Arch. Biochem. Biophys., Orlando, v.80, p.199-209, 1959.

ZHAO, F.J., EVANS, E.J., BILSBORROW, P.E., SYERS, J.K. Sulphur uptakè and distribution in double low and single low varieties of oilseed rape (Brassica napus L.). Plant Soil, Dordrecht, v.150, p.69-76, 1993. 
ZIEVE, L., DOIAZAKI, W.M., ZIEVE, F.J. Synergism between mercaptans and ammonia or fatty acids in the production of coma: a possible role for mercaptans in the pathogenesis of hepatic coma. J. Lab. Clin. Med., St. Louis, v.83, p. 16-28, 1974.

ZIEVE, L. The mecanism of hepatic encephalopathy. Hepathology, Baltimore, v.1, p. $360-365,1981$. 